\title{
Interventions for helping people recognise early signs of recurrence in bipolar disorder (Review)
}

Morriss R, Faizal MA, Jones AP, Williamson PR, Bolton CA, McCarthy JP

Morriss R, Faizal MA, Jones AP, Williamson PR, Bolton CA, McCarthy JP.

Interventions for helping people recognise early signs of recurrence in bipolar disorder.

Cochrane Database of Systematic Reviews 2007, Issue 1. Art. No.: CD004854.

DOI: 10.1002/14651858.CD004854.pub2.

www.cochranelibrary.com 
TABLE OF CONTENTS

ABSTRAC 1

PLAIN LANGUAGE SUMMARY

BACKGROUND

OBJECTIVES

METHODS

RESULTS

DISCUSSION

AUTHORS' CONCLUSIONS

ACKNOWLEDGEMENTS

REFERENCES

CHARACTERISTICS OF STUDIES

DATA AND ANALYSES

Analysis 1.1. Comparison 1 Treatment as usual (TAU) versus TAU and additional early warning sign recognition, Outcome 1 Time to first recurrence of any type.

Analysis 1.2. Comparison 1 Treatment as usual (TAU) versus TAU and additional early warning sign recognition, Outcome 2 Time to manic/hypomanic episode.

Analysis 1.3. Comparison 1 Treatment as usual (TAU) versus TAU and additional early warning sign recognition, Outcome 3 Time to depressive episode.

Analysis 1.4. Comparison 1 Treatment as usual (TAU) versus TAU and additional early warning sign recognition, Outcome 4 Percentage of people hospitalised.

Analysis 1.5. Comparison 1 Treatment as usual (TAU) versus TAU and additional early warning sign recognition, Outcome 5 Measure of functioning.

Analysis 2.1. Comparison 2 Heterogeneity, Outcome 1 EWS intervention vs psychological control group for time to first recurrence of any type.

Analysis 2.2. Comparison 2 Heterogeneity, Outcome 2 EWS intervention vs psychological control group for time to manic/ hypomanic episode.

Analysis 2.3. Comparison 2 Heterogeneity, Outcome 3 EWS intervention vs psychological control group for time to depressive episode.

Analysis 2.4. Comparison 2 Heterogeneity, Outcome 4 Time to first recurrence of any type for TAU Vs enhanced TAU. .............

Analysis 2.5. Comparison 2 Heterogeneity, Outcome 5 Time to first recurrence of any type for Intervention delivered in groups vs individually.

Analysis 2.6. Comparison 2 Heterogeneity, Outcome 6 Inclusion one month after episode vs recruitment during episode. ....... Analysis 2.7. Comparison 2 Heterogeneity, Outcome 7 Time to first recurrence of any type for simple VS complex intervention for EWS.

Analysis 2.8. Comparison 2 Heterogeneity, Outcome 8 Time to manic/hypomanic episode for simple Vs complex intervention for EWS.

Analysis 2.9. Comparison 2 Heterogeneity, Outcome 9 Time to depressive episode for simple Vs complex intervention for EWS.

Analysis 2.10. Comparison 2 Heterogeneity, Outcome 10 Time to first recurrence in studies where EWS as primary focus Vs EWS as secondary focus.

Analysis 2.11. Comparison 2 Heterogeneity, Outcome 11 Time to manic episode in studies where EWS as primary focus Vs EWS as secondary focus.

Analysis 2.12. Comparison 2 Heterogeneity, Outcome 12 Time to depressive episode in studies where EWS as primary focus Vs EWS as secondary focus.

ADDITIONAL TABLES

WHAT'S NEW

HISTORY

CONTRIBUTIONS OF AUTHORS

DECLARATIONS OF INTEREST

SOURCES OF SUPPORT

INDEX TERMS 
[Intervention Review]

\section{Interventions for helping people recognise early signs of recurrence in bipolar disorder}

Richard Morriss ${ }^{1}$, Mohammad Amir Faizal2 ${ }^{2}$, Ashley P Jones ${ }^{3}$, Paula R Williamson ${ }^{4}$, Catherine A Bolton 5 , James P McCarthy 6

1Psychiatry, University of Nottingham , Nottingham, UK. 2Psychiatry, Mersey Care NHS Trust, Liverpool, UK. 3Institute of Child Health, University of Liverpool, Liverpool, UK. ${ }^{4}$ Centre for Medical Statistics and Health Evaluation, University of Liverpool, Liverpool, UK. ${ }^{5}$ Child and Adolescent Mental Health Service, Royal Bolton Hospital Trust, Bolton, UK. ${ }^{6}$ Ferndale Unit, Merseycare NHS Trust, Liverpool, UK

Contact: Richard Morriss, Psychiatry, University of Nottingham, A Floor, South Block, Nottingham, NG7 2UH, UK. richard.morriss@nottingham.ac.uk.

Editorial group: Cochrane Common Mental Disorders Group.

Publication status and date: Edited (no change to conclusions), published in Issue 1, 2010.

Citation: Morriss R, Faizal MA, Jones AP, Williamson PR, Bolton CA, McCarthy JP. Interventions for helping people recognise early signs of recurrence in bipolar disorder. Cochrane Database of Systematic Reviews 2007, Issue 1. Art. No.: CD004854. DOI: 10.1002/14651858.CD004854.pub2.

Copyright ( 2010 The Cochrane Collaboration. Published by John Wiley \& Sons, Ltd.

\section{A B S T R A C T}

\section{Background}

Recurrence rates for bipolar disorder are high despite effective treatments with mood stabiliser drugs. Self-help treatments and psychological treatments that teach patients to recognise and manage early warning symptoms and signs (EWS) of impending manic or depressive episodes are popular with patients. The main aim of such interventions is to intervene early and prevent bipolar episodes, thereby increasing the time to the next recurrence and preventing hospitalisation.

\section{Objectives}

To compare the effectiveness of an EWS intervention plus treatment as usual (TAU) versus TAU (involving and not involving a psychological therapy) on time to manic, depressive and all bipolar episodes (the primary outcome), hospitalisation, functioning, depressive and manic symptoms.

\section{Search methods}

Relevant studies identified by searching Cochrane Collaboration Depression, Anxiety and Neurosis Controlled Trials Registers (CCDANCTRStudies and CCDANCTR-References - searched on 20/10/2005), supplemented with hand searching the journal Bipolar Disorders, searching the UK National Research Register, checking reference lists of included studies and contacting authors.

\section{Selection criteria}

Only randomised controlled trials (RCTs) were included. Participants were adults with a diagnosis of bipolar disorder based on standardised psychiatric criteria.

\section{Data collection and analysis}

Two reviewers independently rated trials for inclusion. Data were extracted from included trials by reviewers using a data extraction sheet. Authors of all the included studies were contacted for any additional information required. Time to recurrence data was summarised as log hazard ratios, dichotomous data as relative risk and continuous data as weighted mean difference, using random effects models to calculate effect size only when there was heterogeneity in the data. 


\section{Main results}

Eleven RCTs were identified, but only six provided primary outcome data. All six RCTs were of high quality. Time to first recurrence of any type (RE, hazards ratio $0.57,95 \% \mathrm{Cl} 0.39$ to 0.82 ), time to manic/hypomanic episode, time to depressive episode, and percentage of people hospitalised and functioning favoured the intervention group. Neither depressive nor hypomanic symptoms differed between intervention and control groups.

\section{Authors' conclusions}

This review shows a beneficial effect of EWS in time to recurrence, percentage of people hospitalised and functioning in people with bipolar disorder. However, the absence of data on the primary outcome measure in so many included studies is a source of concern and a potential source of bias. Mental health services should consider routinely providing EWS interventions to adults with bipolar disorder, as they appear to reduce hospitalisation and therefore may be cost-effective.

\section{PLAIN LANGUAGE SUMMARY}

Interventions for helping people recognise early signs of recurrence in bipolar disorder

Bipolar disorder (BPD), or manic-depressive psychosis, is a common and severe mental illness, with a lifetime prevalence of 1-2\%. BPD is characterised by two types of recurrence, mania and depression. High rates of recurrence and associated adverse consequences occur in spite of a range of effective treatments. Early warning signs (EWS) interventions, targeted at improving the recognition and selfmanagement of manic and depressive symptoms, are intended to train people with recurrent bipolar affective disorder to recognise early warning signs of recurrence and to avert adverse outcomes. This review demonstrated that these interventions, in addition to treatment as usual (TAU), including medication and regular appointments with health professionals, have benefits on time to recurrence and hospitalisation. Compared with TAU only, EWS interventions also resulted in improved functioning at eighteen months, although these data were sparse and the findings should be interpreted with caution. EWS interventions did not appear to have any effect on depressive or manic symptoms, although again, these findings were based on small numbers of potentially selected patients in remission. It should be noted that EWS was used along with other psychological interventions, and it is not entirely clear what proportion of the beneficial effect was due to the EWS intervention alone. 


\section{B A C K G R O U N D}

Bipolar disorder (BPD), or manic-depressive psychosis, is a common and severe mental illness with a lifetime prevalence of one to two per cent (Robins 1984; ten Have 2002 ). BPD is characterised by two types of recurrence, mania and depression. Mania is characterised by periods of elation or irritable mood lasting at least four days, coupled with other symptoms of overactivity, reduced need for sleep, disinhibition, increased self-esteem or grandiosity and increased talkativeness (APA 1995). Depression is characterised by core symptoms of depressed mood and loss of interest for at least two weeks, coupled with other symptoms such as changes in sleep pattern, appetite and concentration, low selfesteem, hopelessness, self-blame and suicidal ideation. Psychotic symptoms such as delusions and hallucinations are seen in a substantial proportion of patients in either the manic or depressed phases of the disorder. Recurrence rates are high, at around 50 per cent at one year, and 70 per cent at four years (Coryell 1989; Harrow 1990; Tohen 1990; O'Connell 1991; Keller 1992; Gitlin 1995) after a manic episode, in modern naturalistic studies. BPD patients were found to be symptomatic with recurrence or inter-episode symptoms of mania or depression for 47 per cent over a mean follow up of 13 years (Judd 2002). Recurrence and inter-episode symptoms impair function, marital relationships, employment and quality of life (Gitlin 1995; Ozer 2002; Judd 2002). There is a high lifetime prevalence of attempted suicide rate, completed suicide, and also risks to others through violence, neglect of dependents or reckless behaviour (Goodwin 1990; Morriss 2002).

High rates of recurrence and their adverse consequences occur in spite of a range of effective treatments such as mood stabilisers (Bowden 2000; Burgess 2003). Surveys of patient organisations in UK and US reveal a strong wish by patients for both self-help and psychological treatments in addition to pharmacotherapy (Lish 1994; Hill 1996). Self-help treatments may empower patients and enable them to take more control over their care and life decisions.

One form of self-help treatment and psychological intervention is to teach BPD patients to recognise early signs of the recurrence of mania and depression (Perry 1995; Perry 1999). This type of secondary prevention is widely used in medicine e.g. to promote early treatment of hypoglycaemia in diabetes mellitus or myocardial infarction. The approach has been practiced for many years in BPD patients (Jacobson 1965). Three retrospective studies (Molnar 1988; Smith 1992; Lam 1997) and two prospective studies (Altman 1992; Keller 1992) showed identifiable and consistent early or "prodromal" symptoms of manic or depressive recurrence at two to four weeks before full recurrence in most patients with BPD. These prodromal symptoms are idiosyncratic to both the individual and type of recurrence (mania or depression). They may be more consistent and easier to recognise for mania than depression (Molnar 1988, Smith 1992). The definition of prodromal symptoms that represent the focus of the present review is early warning signs (EWS) of impending recurrence for persons already diagnosed with bipolar disorder. These prodromal symptoms are distinct in definition from those prodromal changes that precede the initial onset of major mental disorder (Bustillo 1995).

Individuals who cope well with the prodromal symptoms of mania and depression are less likely to be hospitalised (Joyce 1985) and show improved social and occupational function (Lam 1997). Cognitive behaviour therapy targeted at improving the recognition and self-management of manic and depressive prodromes has been reported as effective in delaying both depressive and manic recurrence (Lam 2000; Lam 2003). Recognition of EWS may also avert adverse outcomes. For instance, in the event of an episode, plans can be made for child care so that children are not neglected, for financial control to prevent reckless spending, and avoidance of previous circumstances that in the past have led to violence or reoffending.

Adverse outcomes from self-monitoring of early recurrences of BPD have been reported, with interventions involving the identification and management of EWS (Morriss 2004). Patients may become over-confident that they can use these techniques to prevent recurrence, and stop their mood-stabilising medication prematurely. Individuals in the prodrome of depression may ruminate on their depression with a further worsening of their depressive symptoms. False alarms may occur, and people may seek more hospital care or receive higher doses of medication such as antidepressants without any obvious benefit (Perry 1999).

Recent work has indicated that the effectiveness of CBT in bipolar disorder on time to any recurrence and symptoms of depression and mania was confined to patients without numerous previous bipolar episodes (Scott 2006 ). A large number of previous bipolar episodes has been associated with neuropsychological impairment (Denicoff 1999) and poor handling of stress (Hammen 1997). However, age, gender and baseline medication did not influence the effectiveness of the EWS intervention (Perry 1999). Thus, it is predicted that the effectiveness of interventions for EWS might vary according to number of previous bipolar episodes.

At present, the precise mechanism of action of EWS interventions in delaying recurrence in BPD remains unclear. EWS interventions appear effective in BPD patients who show good or poor adherence to medication (Colom 2003b; Colom 2003c). Time spent with a therapist does not explain the effectiveness of EWS interventions (Colom 2003b; Colom 2003c). EWS interventions may be effective because milder symptoms in the early stage of recurrence are easier to treat than more severe symptoms later in the recurrence. Patients report feeling more confident about returning to work and taking on other responsibilities in their lives, because EWS interventions forewarn the patient of a recurrence in time for the BPD patient to prevent any serious harm to their lives (Perry 1999; Morriss 2004).

Previous research has indicated that family members detect early warning signs later than the person diagnosed with schizophrenia (Birchwood 1989). Given this finding and other research indicating that some EWS in bipolar disorder are likely to be subjectively perceived (for example, changes in perception of colours and noise), EWS interventions should be more effective when the person with bipolar disorder is trained to recognise early signs rather than the carer. However, inclusion of family members in training might enhance the outcome of EWS interventions because they may recognise additional EWS signs due to behaviour ( for example playing particular pieces of music), can be a point of reference if the patient wants to discuss the significance of an EWS, and can provide both practical help and emotional support.

There is encouraging evidence of the potential benefits of relapse prevention in serious mental illness (Mueser 2002). There is no systematic review of the clinical effectiveness of the range of self-help, medication, psycho-education and 
psychotherapy (principally cognitive behaviour therapy and family therapy) approaches that incorporate the recognition and prompt management of early or prodromal symptoms of recurrence. The primary target of such interventions is to increase time to the next recurrence and reduce recurrence, but there may be additional benefits in terms of improving social and occupational function, quality of life, depressive symptoms and patient empowerment. There is some evidence to suggest that persons with minimal training are able to teach these skills (see Perry 1999). One implication might be that people who use services could train other service users in these potentially efficacious techniques, thus making the intervention more widely available. This review seeks to examine whether participation of caregivers in training influences the effectiveness of the intervention. The review also aims to investigate whether outcomes differ significantly if EWS represents the primary focus of the intervention or is only one of a number of techniques taught.

\section{OB JECTIVES}

The overall aim was to conduct a systematic review of all intervention studies that included systematically teaching the recognition of early warning signs (EWS) of recurrence to people diagnosed with bipolar disorder and/or their carers. The objectives were:

1. To compare the effectiveness of an EWS intervention plus treatment as usual (TAU) versus TAU not involving a psychological therapy on time to manic, depressive and all bipolar episodes.

2. To compare the effectiveness of an EWS intervention plus TAU versus TAU plus another psychological therapy on time to manic, depressive and all bipolar episodes.

3. To compare the effectiveness of intermittent medication used on recognition of EWS without continued mood stabilising medication versus TAU involving continued mood stabilising medication on time to manic, depressive and all bipolar episodes.

\section{ME T HO D S}

\section{Criteria for considering studies for this review}

\section{Types of studies}

\section{Inclusion criteria}

Only randomised controlled trials were included. Studies were not excluded on the basis of language, country of origin or publication status.

\section{Exclusion criteria}

Studies that were not randomised controlled trials were excluded. These included case series, pre and post-intervention studies and those studies with a non-random allocation from waiting list.

\section{Types of participants}

\section{Inclusion criteria}

Adults with a diagnosis of bipolar disorder or associated diagnoses based on standardised psychiatric criteria (including Research Diagnostic Criteria, DSM IV, ICD-10). Adults were included at any stage of the disorder and in any treatment setting.

\section{Exclusion criteria}

The review excluded studies of participants where:
1. The primary diagnosis was another disorder (for example, panic, eating disorders)

2. Participants were selected on the basis of a non-psychiatric medical condition (for example, cancer, human immune deficiency syndrome)

3. People aged sixteen or under

4. People living exclusively in institutions e.g. nursing home, prisons but not excluding temporary care arrangements such as hospitalisation

5. 'At risk' populations who have not yet received a definite diagnosis of bipolar disorder.

\section{Types of interventions}

\section{Inclusion criteria}

Interventions designed to systematically train people with a diagnosis of bipolar disorder to recognise early warning signs of recurrence of episodes were included. Each person in the study must have received at least one hour of training specifically in recognising and managing EWS. EWS interventions require detailed history taking, with or without additional techniques such as diary keeping and card sorting techniques, and a plan of action based on the EWS. Therefore, EWS interventions required at least one hour of face to face clinical contact. Any intervention that included EWS interventions either as a major focus or as one component of an intervention package was included. The interventions might be individually based or group based. The interventions to be included would also encompass self-help approaches. Studies involving family members or carers were also included. EWS interventions were be included if they were carried out in community, primary care or secondary care settings.

During abstract review, in the absence of an explicit description of early warning signs training, studies where the intervention was described as cognitive, family, psychosocial, education, selfmonitoring, interpersonal, relapse prevention, self-help, problemsolving, counselling or targeted/intermittent medication were considered as potentially including EWS interventions.

The following comparisons were to be made:

1. To compare the effectiveness of an EWS intervention plus treatment as usual (TAU) versus TAU not involving a psychological therapy on time to manic, depressive and all bipolar episodes 2. To compare the effectiveness of an EWS intervention plus TAU versus TAU plus another psychological therapy on time to manic, depressive and all bipolar episodes

3. To compare the effectiveness of intermittent medication used on recognition of EWS without continued mood stabilising medication versus TAU involving continued mood stabilising medication on time to manic, depressive and all bipolar episodes.

\section{Exclusion criteria}

Studies where both groups simultaneously received the same psychological intervention involving EWS were excluded (for example, psychological therapy versus psychological therapy in addition to medication).

\section{Types of outcome measures}

Primary outcome

1. Time to first recurrence of any type.

\section{Secondary outcomes}


1. Manic, hypomanic or mixed affective episodes and time to depressive episodes.

2. Percentage of people who were hospitalised.

3. Measures of symptoms, functioning and medication, where available at 3,6, 12, 18 and 24 months or more after baseline: Functioning: Social functioning/interpersonal functioning, occupational functioning (e.g. MRC Social Performance Scale (Hurry 1983).

Symptoms: Continuous measures of symptoms (depression on Beck Depression Inventory; BDI (Beck 1961); Hamilton Depression Rating Scale; HDRS (Hamilton 1960); MontgomeryAsberg Depression Rating Scale; MADRS (Montgomery 1979); Hospital Anxiety and Depression Scale; HAD (Zigmond 1983); mania on Bech Rafaelsen Mania Scale (Bech 1978); Young Mania Scale (Young 1978); Longitudinal Interval Follow-up Evaluation; LIFE (Keller 1987); Internal States Scale (Bauer 1991); Altman Mania Scale (Altman 1997).

Medication: $\mathrm{mg}$ equivalents of chlorpromazine, imipramine, diazepam, lithium, valproate, carbamazepine.

4. As a measure of acceptance of the intervention, satisfaction with treatment approach.

We also considered other outcomes that might be particularly important to consumers such as quality of life (EuroQol Group 1990) and perceived control over illness (Lam 1997).

\section{Search methods for identification of studies}

\section{Electronic bibliographic databases}

Electronic searches were undertaken using Cochrane Collaboration Depression, Anxiety and Neurosis controlled trials registers (CCDANCTR-Studies and CCDANCTR-Studies).

Electronic search terms were:

CCDANCTR-Studies - searched on 20/10/2005

Diagnosis = "Affective Disorder" or "Affective Psychosis, Bipolar" or "Bipolar Depression" or "Bipolar I Disorder" or "Bipolar II Disorder" or "Cyclothymic Disorder" or "Depression, Psychotic" or "Depression, Recurrent" or "Excited Psychosis" or "Major Affective Disorders" or "Mania" or "Manic Disorder" or "Bipolar Affective Disorder" or "Bipolar Not Otherwise Specified" or "Schizoaffective Disorder" or "Psychoses" or "Psychotic Disorders".

and

Intervention= "Clinical Status" or "Cognitive Behavioral Therapy" or "Cognitive Therapy" or "Consumer Advocacy" or "Consumer Led Care" or "Early Intervention" or "Education" or "FamilyFocused Psychoeducational Therapy" or "Family Therapy" or "Group Therapy" or "Inpatient Family Intervention" or "Marital Therapy" or "Monitoring" or "Self-Directed Health and Social Care Use" or "Psycho education or "Psychotherapy" or "Self-Evaluation" or "Self Monitoring" or "Skills Training" or "Spouses".

CCDANCTR-References - searched on 20/10/2005

Keyword $=$ Bipolar $^{\star}$ or Mania or Manic ${ }^{\star}$ or Cyclothymic

and

Free-Text $=$ "Clinical Status" or "Cognitive Behavioral Therapy" or "Cognitive Therapy" or "Consumer Advocacy" or "Consumer Led Care" or "Early Intervention" or Education or "Family-Focused Psychoeducational Therapy" or "Family Therapy" or "Group Therapy" or "Inpatient Family Intervention" or "Marital Therapy" or "Monitoring" or "Self-Directed Health and Social Care Use" or "Psychoeducation" or "Psychotherapy" or "Self-Evaluation" or "Self Monitoring" or "Skills Training " or "Spouses" or "relapse prevention" or "early warning"

\section{Handsearches}

A hand search of all issues of Bipolar Disorders was carried out

\section{NHS National Research Register (NRR)}

This was inspected for information regarding ongoing research trials.

\section{Reference Lists}

All reference lists of selected studies and relevant reviews were inspected for additional relevant titles

\section{Personal communication}

We contacted researchers who have previously published in this area

\section{Data collection and analysis}

\section{Decision to include or exclude study from review}

\section{Inspection of citations}

All abstracts were independently reviewed by two out of three review authors (MAF, RM) with reference to the inclusion/exclusion criteria, and a decision was made whether to retrieve the full report of the study. The number of abstracts identified, accepted and rejected was recorded.

\section{Inspection of retrieved reports}

Once the full reports were retrieved, they were inspected for relevance to the review and inclusion and exclusion criteria applied. Studies not meeting the predetermined criteria were excluded. A record was made of the number of papers retrieved, the number of papers excluded and the reasons for exclusion.

\section{Data extraction}

A formal data extraction form was designed. Information regarding methods, participants, comparison groups, interventions and outcomes (noting where primary and secondary outcomes were not measured, or measured but not reported) was tabulated. Data were recorded to assess potential sources of clinical heterogeneity, including study design, participant characteristics and aspects of intervention content and delivery. All included studies were rated according to methodological quality criteria (see following section). Data extraction was performed by MF and JMcC, except for time to recurrence data, which were extracted by $\mathrm{AJ}$ and $\mathrm{PW}$.

\section{Determining whether described intervention included training in recognising and managing EWS}

The essential elements of early warning signs (EWS) monitoring were defined as:

1. Education to increase awareness of EWS and identification of these EWS

2. Person with bipolar disorder learning to self-monitor for EWS (e.g. mood monitoring), or carers and/or health professionals learning to monitor on behalf of the person with bipolar disorder 3. Early action to prevent development of recurrence (e.g. early help seeking or self-coping methods).

Where the information was ambiguous in the original report, attempts were made to contact the corresponding author of the study, or the first or most senior author when the corresponding 
author was not designated. A standard letter was sent by post or e-mail requesting the authors to clarify whether the intervention included early warning signs training, and if yes, whether the intervention was systematically employed with all participants. A further letter was mailed if the author did not respond to the initial letter. If there was no response to the second mailing, the study was then excluded from any further analysis.

\section{All studies were categorised by:}

- Target of intervention: 1 . Interventions targeted at patient's own recognition of early warning symptoms; 2 . Interventions targeted at recognition of early warning symptoms by carers or health professionals; 3 . Interventions targeted at both patient and carer

- Individual or group treatment

- Focus of intervention: EWS was primary focus of intervention or one component of a multifaceted intervention

- Intervention as an addition or replacement for treatment as usual (TAU): 1 . Intervention targeting early warning symptoms plus TAU versus TAU not including psychological treatment; 2. EWS intervention plus TAU versus another psychological treatment not involving EWS plus TAU; 3. EWS intervention with intermittent medication use in presence of EWS without continued mood stabiliser medication versus TAU using continued mood stabiliser medication

- EWS intervention involved only help-seeking from others, or EWS intervention involved other self-directed coping

- RCT involved euthymic BPD patients or BPD patients who were in depressive episode

- RCT included BPD patients with axis 1 or axis 2 psychiatric comorbidity (APA 1995) or excluded patients with axis 1 or 2 comorbidity.

\section{Assessing methodological quality of studies}

All RCTs were assessed for methodological quality. The items assessed were allocation concealment, method of randomisation, blinding, whether an intention to treat analysis was used and attrition. Allocation concealment and the method of randomisation were rated as either clear, unclear or inadequate. When the analysis reported was not an intention to treat analysis, we contacted the authors to try to obtain the results from the intention to treat analysis. Loss to follow-up was rated as either adequate ( 80 per cent or more follow-up) or inadequate (less than 80 per cent followup). Blinding was reported as either single, double or open, and where possible, we reported who was blinded in the trial. It was not possible to explore each of these methodological factors in a meta-regression as planned in the protocol, due to the sparsity of information available in the trials. Missing data were not imputed according to a best/worse case scenario, because the primary outcome was time to event data rather than categorical data.

\section{Methods of statistical analysis}

\section{Treatment outcomes}

The treatment outcomes relevant to this study were measured as time to recurrence of episodes, measures of symptoms and outcomes presented as dichotomous (hospitalisation/no hospitalisation) or continuous (means and standard deviations on rating scales).
Dichotomous data were summarised in terms of relative risks. Time to recurrence data were summarised in terms of log hazard ratios. Log hazard ratios and the standard errors of the log hazard ratios were entered into Review Manager software, and analysed using the generic inverse variance method. These data were extracted from the published papers using the methods described by Parmar (Parmar 1998). Continuous data such as medication, symptomatology and functioning measured with standardised, published measures were summarised in terms of a difference in means, provided skewness was not too great. Continuous data were classed as being skewed if the standard deviation was over half the size of the mean (this is only true if the data can take positive values only, it does not apply to change data, for example). Skewed data were not pooled, and the results were presented in additional tables, with no statistical analyses performed on these data. Where this was the case, we contacted the study authors to obtain the change from baseline data that could be included in the analyses. Where data had been reported at a number of different time points throughout the course of a study, we reported when data had been measured within the trial, what had been reported within the published paper, and combined the data at clinically relevant intervals. Methods for the meta-analysis of continuous aggregate longitudinal data have been described (Jones 2005), and the method that was applied to the data in this review were analysis at independent time points, thus ignoring the correlation between the time points within an individual study.

\section{Meta-analysis}

We aimed to conduct three types of meta-analysis:

- Intervention targeted at recognition of EWS plus TAU versus TAU not involving psychological treatment

- Intervention targeted at recognition of EWS plus TAU versus another psychological control therapy plus TAU

- Intervention targeted at recognition of EWS coupled with intermittent medication use without continued mood stabilising medication versus TAU using continued mood stabilising medication.

Once the results of each study were summarised using an effects measure, an average value of the effect was computed across studies using either a 'fixed effect' model, if there was little heterogeneity, or a 'random effects' model when there was unexplained heterogeneity.

\section{Heterogeneity}

If clinical heterogeneity was too great, or methodological quality too poor, studies were not pooled in a meta-analysis. A chi-squared test for heterogeneity was undertaken, and the I-squared statistic was calculated. If statistical heterogeneity was indicated $(p<0.1)$, then attempts were made to further investigate potentially influential study characteristics via metaregression. Random effects modelling was employed where significant residual heterogeneity existed. A distinction was made between quantitative and qualitative heterogeneity.

It was acknowledged that certain subgroup analyses might not be possible due to limited number of studies or insufficient information available. Where this occurred, a qualitative review of information was completed if possible. The following subgroup analyses were planned:

\section{Choice of methods for pooling of data}


- depressed episode (presence or absence) at baseline

- axis 1 or axis 2 comorbidity (presence or absence) at baseline

- EWS as primary focus of the intervention or as part of another intervention

- EWS intervention delivered to patient only or patient and carer or health professional

- EWS intervention delivered to carer only versus carer and patient

- EWS intervention delivered individually versus group intervention

- EWS intervention promotes only help seeking from others versus additional self-directed coping.

\section{Publication bias}

Publication bias was assessed by visual inspection of funnel plots. Consideration was given to within-study selective reporting bias (Hahn 2000; Williamson 2005).

\section{RE S U L T S}

\section{Description of studies}

Electronic searches of the CCDAN Controlled Trials Register were conducted to identify relevant studies. Thirty-five studies were relevant, based on the abstracts. These papers were obtained and scrutinised by two review authors (RM and MF). Eight of these met our inclusion criteria. Hand searching of the Bipolar Disorders journal revealed four relevant abstracts, of which only one met our inclusion criteria when the full paper was obtained (Meyer 2003, included under Ongoing studies). None were included from the reference list of other included studies. Two other papers were included after reviewing the original paper when they were published (Lam 2005; Scott 2006). In total, eleven studies met our inclusion criteria. One of the studies was reported twice (Lam 2003; Lam 2005) and another was reported three times (Simoneau 1999; Miklowitz 2000; Miklowitz 2003). One was an ongoing study (Meyer 2003). There is an additional ongoing study that is likely to be relevant to the review, but at present we do not have data (Ball 2003).

\section{Excluded studies}

Please refer to Table of Excluded Studies for details of individual trials.

\section{Ongoing trials}

One study (Meyer 2003) was presented as a conference proceeding, and the author supplied us with the first three months follow-up results. The author was contacted for further results, but we did not receive any further data. We have contacted the author of another study which has published its methodology (Ball 2003), but we have not received any data from that study.

\section{Included studies}

Three studies were duplicate reports (Lam 2003; Simoneau 1999, Miklowitz 2000) and 11 studies (of which one was ongoing) met our inclusion criteria. The studies are described in the Table of Included Studies.

\subsection{Methods}

All trials were RCTs, but none were able to use a double blind technique due to difficulties in blinding psychosocial interventions. All studies tried to reduce bias by using independent outcome assessors, except three trials where blinding of the assessors was not mentioned (Van Gent 1991; Scott 2001; Meyer 2003) . The duration of follow-up ranged from 12 months to 24 months, except one trial where participants were followed up for only six months (Van Gent 1991).

\subsection{Participants}

All trials included people with a diagnosis of bipolar disorder, aged $>18$ years. All employed operational criteria for diagnosis (DSM-111-R, DSM-IV). Most of the trials used structured assessment (SCID, SADS) to arrive at the diagnosis, except two trials which used the opinion of senior psychiatrists (Colom 2003c; Colom 2003b ), one study did not specify anything (Lam 2000), and another trial used the opinion of two independent psychiatrists (Van Gent 1991). Axis 1 and axis 2 psychiatric comorbidity were included in eight of the trials (Colom 2003c; Colom 2003c(a); Lam 2003; Meyer 2003; Perry 1999; Scott 2001; Scott 2006; Simon 2004). Other trials excluded axis 1 and axis 2 psychiatric morbidity or did not state whether these morbidities were included or excluded.

\subsection{Interventions}

In all studies, treatment as usual (TAU) included treatment with medication and outpatient appointments with a psychiatrist. In two trials (Colom 2003c; Colom 2003b), TAU was supplemented by 20 sessions of non-structured group meetings. In all studies, EWS interventions provided education to the patient about the nature of bipolar disorder, as well as early warning sign recognition and management, in addition to TAU. The interventions ranged from five sessions (Van Gent 1991) to 221 sessions (Colom 2003c; Colom 2003b). The interventions for managing EWS, once recognised by the patient, ranged from complex individual approaches such as cognitive therapy (e.g. Lam 2003, Scott 2006) to simple individual approaches that involved seeking an urgent appointment with health professionals (Perry 1999), and also group and family focused psychoeducation (e.g. Colom 2003c; Colom 2003c; Miklowitz 2000). There were no studies utilising EWS interventions with intermittent medication.

\subsection{Outcomes}

\subsubsection{Time to any relapse}

Six trials reported time to any relapse ( Colom 2003c; Colom 2003b; Lam 2003; Miklowitz 2000; Perry 1999; Scott 2006).

\subsubsection{Time to manic/hypomanic or depressive episode}

Time to manic/hypomanic or depressive episode were reported by four trials (Colom 2003c; Lam 2005; Perry 1999; Scott 2006) . Another four trials reported time to depressive episode (Colom 2003c; Lam 2003; Perry 1999; Scott 2006) . One trial reported mixed recurrence (Colom 2003c). Some trials (Simon 2004; Lam 2000; Van Gent 1991; Scott 2001) reported outcomes that could not be used due to incomplete information.

\subsubsection{Percentage of people hospitalised}

These were reported in four of the trials (Colom 2003c; Colom 2003b; Perry 1999; Simon 2004). Lam 2000 reported that mean number of hospitalisations was not significant when adjusted, but did not provide the number of people admitted. Two trials reported on hospitalisation, but did not specify the number of people in control and intervention groups who were hospitalised (Miklowitz 2003; Scott 2001), and hence the data could not be analysed. Number of days spent in hospital was recorded by two trials (Perry 1999; Meyer 2003). 


\subsubsection{Depressive symptoms}

Lam 2000 and Lam 2003 reported on depressive symptoms measured by the Beck Depression Inventory (BDI) and Hamilton Depression Rating Scale (HDRS). Authors of Perry 1999 and Scott 2006 supplied us with HDRS scores and Scott 2006 supplied BDI scores. Data on BDI and HDRS could not be extracted from Lam 2003, because they were incomplete.

\subsubsection{Manic symptoms}

Authors of Perry 1999 and Scott 2006 provided Bech Rafaelsen Mania Scale (BRMS) scores.

\subsubsection{Measure of functioning}

Two trials reported on social functioning measured by MRC social performance scale (Lam 2000; Perry 1999). Scott 2001reported functioning by Global Assessment of Function (GAF) and Work and Social Adjustment Scale (WASA) scores, but these could not be translated into scores on the MRC social performance scale.

Secondary outcomes of satisfaction with the intervention, quality of life and perceived control over illness, that were outlined in the protocol, could not be analysed due to the absence of complete information in the original reports.

\section{Risk of bias in included studies}

For further information please refer to additional Table 1 'Methodological quality of included studies'.

All trials included were randomised controlled trials. Three trials did not report the method of randomisation (Lam 2000; Meyer 2003; Van Gent 1991). Blinding was not easy due to the nature of interventions, and most of the trials had independent outcome assessors, with the exception of three trials (Van Gent 1991; Scott 2001; Meyer 2003). None of the trials reported prospective rating of blinding, except one trial (Miklowitz 2003) in which it was reported that it proved difficult to keep assessors unaware of the patients' psychosocial group assignments. It was stated in nine trials that an intention to treat analysis (ITT) was undertaken. Two trials did not state whether an ITT analysis had been performed (Scott 2001;Van Gent 1991).

Six studies were scored as category A (Adequate) for concealment of allocation, four of the studies (Miklowitz 2003; Scott 2001; Van Gent 1991; Lam 2000) were scored as category B (Unclear), and an ongoing study (Meyer 2003) was also scored as B. Please refer to additional Table 1 for details on individual trials.

\section{Effects of interventions}

\section{The search}

Out of the 11 included studies, only six studies reported the primary outcomes outlined in the protocol for this review (Colom 2003c; Colom 2003b; Lam 2005; Miklowitz 2003; Perry 1999; Scott 2006). One trial reported only secondary outcomes outlined in the protocol (Simon 2004). Three of the studies did not report any outcomes that could be used (Scott 2001;Van Gent 1991;Meyer 2003).

\section{Primary outcomes (Table 2)}

\subsection{Time to first recurrence of any type}

Data were available from six trials. The pooled estimate was significant favouring the EWS intervention group (random effects, hazards ratio $0.57,95 \% \mathrm{Cl} 0.39$ to 0.82 ), but the results showed heterogeneity ( $\mathrm{chi}^{2}=16.23, \mathrm{df}=5, \mathrm{p}=0.006$, l-squared $=69.2 \%$ ).

\subsection{Time to manic/hypomanic episode}

Data were available from four trials. The pooled estimate was almost significant favouring the EWS intervention group (random effects, hazards ratio $0.66,95 \% \mathrm{Cl} 0.40$ to 1.06 ), but the results showed heterogeneity (chi $2=9.29, \mathrm{df}=3, \mathrm{p}=0.03, \mathrm{l}$-squared $=67.7 \%$ ).

\subsection{Time to depressive episode}

Data were available from four trials. The pooled estimate was significant favouring the EWS intervention group (random effects, hazards ratio $0.57,95 \% \mathrm{Cl} 0.33$ to 0.99 ), but the results showed heterogeneity (chi2 $=11.97, \mathrm{df}=3, \mathrm{p}=0.007$, l-squared $=74.9 \%$ ).

\section{Secondary outcomes (Table 2)}

\subsection{Percentage of people hospitalised}

Four trials reported this outcome (Perry 1999; Colom 2003c; Colom 2003b; Simon 2004). The pooled estimate was significant favouring the EWS intervention group (fixed effect, RR $0.67,95 \% \mathrm{Cl} 0.47$ to 0.95 ), and the results showed little heterogeneity ( $\mathrm{chi}^{2}=3.03, \mathrm{df}=3$, $p=0.39$, I-squared $=1.0 \%$ ). We intended to do a best/worse case scenario, but there was only one missing set of data values (one of the participants died), and the best/worse case scenario did not make any significant difference to the conclusions.

\subsection{Measure of depressive symptoms}

\subsubsection{BDI Scale}

Post measurement data were obtained from two studies (Lam 2000; Scott 2006). The data showed characteristics of being skewed and were therefore not entered into a meta-analysis. The data (means and standard deviations for each treatment groups) were entered into an additional table (Table 3), and no formal statistical analyses were applied. For the next issue of the review, we intend to contact the authors of the studies to obtain data on change from baseline for each of the groups.

\subsubsection{HDRS scale}

Post measurement data were obtained from three studies (Lam 2000; Perry 1999;Scott 2006). The data showed characteristics of being skewed, and therefore were not entered into a meta-analysis. The data (means and standard deviations for each treatment groups) were entered into an additional table (Table 4), and no formal statistical analyses were applied. For the next issue of the review, we intend to contact the authors of the studies to obtain data on change from baseline for each of the groups.

\subsubsection{BRMS}

Post measurement data were obtained from two studies (Perry 1999; Scott 2006). The data showed characteristics of being skewed, and therefore were not entered into a meta-analysis. The data (means and standard deviations for each treatment groups) were entered into an additional table (Table 5), and no formal statistical analyses were applied. For the next issue of the review, we intend to contact the authors of the studies to obtain data on change from baseline for each of the groups.

3.3.1 MRC Social Performance

This was reported by two studies (Lam 2000; Perry 1999). Post measurement data were obtained from one study (Lam 2000). 
The data showed characteristics of being skewed and therefore were not entered into a meta-analysis. The data (means and standard deviations for each treatment groups) were entered into an additional table (Table 6), and no formal statistical analyses were applied. For the next issue of the review we intend to contact the authors of the study to obtain data on change from baseline for each of the groups. Change from baseline data was reported by one study (Perry 1999) at three time points (6 months, 12 months and 18 months). There was no statistical difference in scores between the two treatment groups at 6 and 12 months, but a statistical difference was reported between the two groups at 18 months.

\section{Heterogeneity}

We examined heterogeneity at various levels in those studies that contributed primary outcome data on time to first bipolar episode.

4.1 Comparison of studies that included psychological component without EWS in TAU and those that had only TAU in control groups Four of the trials included TAU alone for the control group (Lam 2005; Perry 1999; Scott 2006; Miklowitz 2003). Two studies included psychological intervention that did not include EWS component along with TAU (Colom 2003c; Colom 2003b) to control for the nonspecific effects of psychological treatment, including time spent with therapists.

The sub-group analysis for time to any recurrence can be seen in Figure 02 02, and the results are presented in Table 7 . The metaregression analysis showed no significant difference for this factor (Table 8).

Time to manic/hypomanic episode (Table 9) was reported by three of the above non-psychological TAU trials ( Perry 1999; Lam 2003; Scott 2006 ) and one of the non-EWS psychological group TAU trials (Colom 2003c). The sub-group analysis can be seen in Figure 0202. A meta-regression was not carried out for this factor, due to the lack of information in a number of studies.

Time to depressive episode (Table 10) was reported by three nonpsychological TAU studies (Perry 1999; Scott 2006; Lam 2003) and one of the psychological TAU studies (Colom 2003c). The sub-group analysis can be seen in Figure 02 03. A meta-regression was not carried out for this factor, due to the lack of information in a number of studies.

\subsection{Time to first recurrence of any type for TAU vs enhanced TAU in control group}

In Graph 02 01, we compared time to first recurrence of any type for psychological +TAU Vs non psychological +TAU (section 4.1). Three of the non-psychological TAU trials (Perry 1999; Lam 2003; Scott 2006) used only TAU ,but one of the trials (Miklowitz 2003) used enhanced TAU with two additional sessions to provide education about bipolar disorder in the community, as well as the non-psychological TAU delivered to patients with bipolar disorder as part of routine care. The sub-group analysis can be seen in Figure 02 04. A meta-regression was not carried out for this factor due to the lack of information in a number of studies.

4.3 Time to first recurrence of any type for Intervention delivered in groups vs individually (Table 11)

Three trials delivered the intervention in groups (Colom 2003c; Colom 2003b; Miklowitz 2003) and other three delivered it individually (Perry 1999; Lam 2003; Scott 2006). The results from the sub-group analysis can be seen in Figure 0205 . The meta- regression analysis showed no significant difference for this factor (Table 8).There were insufficient data to compare time to manic/ hypomanic and depressive episodes.

4.4 Time to any recurrence for patients stabilised for at least one month after last acute bipolar episode vs patients recruited during or immediately after (< one month) acute bipolar episode (Table 12)

One of the studies (Scott 2006) recruited patients in an acute bipolar episode and another (Miklowitz 2003) included patients immediately after an acute bipolar episode. The sub-group analysis can be seen in Figure 02 06. The meta-regression analysis showed no significant difference for this factor (Table 8). Heterogeneity was abolished, and EWS interventions were effective in reducing time to the next bipolar episode in trials confined to patients recruited at least one month after remission from an acute bipolar episode. There were insufficient data to explore the effects on manic/hypomanic episode or depressive episodes.

\subsection{Simple vs complex interventions for EWS}

One study examined only the recognition of EWS and seeking help early from health professionals (Perry 1999). The other five studies (Colom 2003c; Colom 2003b; Lam 2003; Scott 2006; Miklowitz 2000) provided the patient and/or family with more complex plans of management for EWS once they were recognised, plus additional help for managing bipolar disorder. The results for time to first recurrence of any type are shown in Table 13 and the sub-group analysis can be seen in Figure 0207.

There was an insufficient number of studies in one of the subgroups to perform a meta-regression.

Time to manic/hypomanic episode results are reported in Table 14 and time to depressive episode are shown in Table 15. The subgroup analyses can be seen in Figures 0208 and 0209 respectively. There was an insufficient number of studies in one of the subgroups to perform a meta-regression.

4.6 EWS interventions where the primary focus is EWS versus interventions where EWS is not the primary focus of the intervention

Five studies were judged to have a primary focus on EWS interventions on the basis of the time devoted to the EWS interventions, the teaching of the EWS intervention early in the treatment and/or the emphasis given to the intervention in the authors' description of the intervention (Colom 2003c; Colom 2003b; Lam 2003; Miklowitz 2000; Perry 1999). Only one study was judged to include EWS, but not as the primary focus of the intervention (Scott 2006).

The results for the time to first recurrence of any type can be seen in Table 16 and in Figure 02 10. There was an insufficient number of studies in one of the sub-groups to perform a meta-regression.

The results for time to manic/hypomanic episode and time to depressive episode can be seen in Table 17 and Table 18, and the sub-group analyses can be in Figures 0211 and 02 12. For both analyses there was an insufficient number of studies in one of the sub-groups to perform a meta-regression. 


\section{DISCUSSION}

There were clinically important findings from the meta-analysis, namely that time to first relapse of any type, time to manic/ hypomanic episode and time to depressive episode favoured the EWS intervention group. Two other clinically relevant findings were the percentage of people hospitalised and measure of functioning, which also favoured the EWS intervention group. However the data on functioning were sparse, based on one relatively small RCT, and only favoured the EWS intervention group at 18 months. In the protocol we had aimed to look at the effectiveness of intermittent medication used on recognition of EWS but there were no studies which satisfied our inclusion criteria. Measures of depressive and hypomanic symptoms did not show any effects of EWS interventions, suggesting that the effects on function may not be related to reducing symptoms that remain between acute bipolar episodes. Treatment that has an impact on depressive and manic type symptoms between acute bipolar episodes are highly desirable, given that people with bipolar disorder have these symptoms between 30-50 per cent of the time (Judd 2002). Most of the participants in this analysis had a diagnosis of Bipolar I, and there were very few with Bipolar II diagnosis. The results of this analysis may not apply to Bipolar II patients.

Some of the pooled estimates showed substantial heterogeneity . However, the forest plots show that they are quantitative rather than qualitative, with the direction of effect favouring the EWS intervention group. A consistency in the results favouring EWS interventions, despite variation in trial characteristics, may be used to support the view that the results are generalisable to a variety of clinical settings. Factors that may have influenced the heterogeneity were considered and examined (see under Table 1 , Table 19, Table 20, Table 21 and forest plots under heterogeneity). The most important factor in terms of investigating heterogeneity was the recruitment in some studies of patients in acute bipolar episode or shortly after the onset of the episode (Scott 2006; Miklowitz 2000). These studies differed from the others, both in patient characteristics and the delivery of the EWS intervention. Scott 2006 employed an intervention where the EWS intervention was not the primary focus of the intervention, while Miklowitz 2000 delivered the intervention through family psychoeducation rather than through targeting the individual. Scott 2006 provided evidence that the number of previous episodes had a bearing on the effectiveness of the psychological intervention involving EWS, with a large number of previous bipolar episodes being associated with increased bipolar recurrence and a smaller number of previous bipolar episodes being associated with decreased bipolar recurrence with the psychological intervention. A reanalysis of data from Colom 2003c, reported in Scott 2006a, also confirms that psychoeducation was not effective in patients with more than 12 previous bipolar episodes. However, the patients in Scott 2006 also included those in acute bipolar episode or on immediate remission from an acute bipolar disorder, while a large proportion had other features generally regarded as having an adverse effect on outcome such as convictions or cautions for violence.

A meta-regression for all potential effect modifiers could not be performed due to small number of included studies. Metaregression for two of the potential effect modifiers was performed. These were (1) the nature of the control group (non-psychological treatment as usual) versus psychological intervention control group and (2) recruited one month or more after episode versus recruited during and soon after episode. The nature of the control group did not explain the heterogeneity, but recruitment of patients during an acute bipolar episode did seem to explain the high degree of heterogeneity in the results. However, there were only a small number of studies included in the analysis. A funnel plot was done to look at publication bias. No conclusions could be made from the funnel plot, due to the small number of studies.

A thorough search strategy was used in this review, which included hand searching of relevant journals. There may still be gaps in the search strategy such as unpublished data (grey literature), which are difficult to get hold of. We included studies where we were confident that an EWS intervention had been attempted. Some trials did not give precise descriptions of the nature of the psychological intervention tested and we did not get a response when we wrote to some authors for clarification. All trials were randomised controlled trials (RCTs), and concealment of allocation was rated as A or B (Table 1). Three studies (Meyer 2003; Scott 2001; Van Gent 1991) did not report intention to treat analysis. Two studies reported using intention to treat principles (Lam 2000; Lam 2003), but there were missing data that were not accounted for in the final reported outcomes. In all included RCTs, outcomes were not blinded, but were independently and systematically obtained with less than 20 per cent missing data. The follow up period in most trials varied from 12 to 24 months, except one trial (Van Gent 1991 ) in which participants were followed up for six months. All trials included personality disorder, with the exception of one trial (Lam 2003), and it was not clear in one other trial (Miklowitz 2000). Axis 1 co-morbidity was included in two of the trials (Perry 1999; Scott 2006 ). Outcome assessments were reported as independent but not blind in all trials except Van Gent 1991. Allocation concealment was adequate for all except two trials (Lam 2000; Miklowitz 2000) providing data for analysis. Some of the studies reported the percentage of people with personality disorders (Colom 2003c; Colom 2003c (a); Perry 1999; Scott 2006 ), substance abuse or dependence (Perry 1999; Scott 2006), but no conclusions could be drawn concerning the effectiveness of EWS interventions in personality disorder and substance use disorders, because few trials reported outcomes in these patient groups, and individual patient data were not available.

A matter of concern in relation to the robustness of our findings is that five out of 11 RCTs provided no primary outcome data, possibly because they did not find a positive outcome, and introducing bias due to selective reporting of outcome measures ( Williamson 2005 a; Hutton 2000). We were unsuccessful in extracting further information on time to relapse on contacting the authors of the other RCTs. These five studies account for 43\% (534/1230) of the total number of people randomised, and one trial included 441 participants (Simon 2004). If the data on the primary outcome were available from these studies (two of these studies were pilot studies for larger RCTs that contained data on the primary outcome (Lam 2000; Scott 2001), then it may be possible that the overall conclusion would be closer to showing no difference between the two interventions. Therefore, the results of the analyses need to be interpreted with caution.

The meta-analysis included a substantial number of patients. Time to first recurrence of any type included data from six studies and 690 participants. Time to manic/hypomanic episode included data from four studies and 533 participants. Time to depressive episode had data from four studies and 533 participants. Meta- 
analysis of percentage of people hospitalised included data from four studies and 679 participants. Less confidence should be placed in the results of EWS interventions on function. The measure of function had data from two studies and 92 participants. The data on hospitalisation comes from four studies involving 679 patients. However, a study with negative clinical outcomes did not provide data on hospitalisation, so again, caution should be applied to this result. The pooled analysis shows clearly for the first time that EWS interventions may reduce the percentage of patients who become hospitalised with an acute bipolar episode. This result may be important because hospitalisation is unpopular with most patients, in short supply and expensive. The savings made from hospitalisation might be used to fund the provision of EWS interventions that are popular with patients, provided they are targeted at patients with bipolar disorder who have a history of hospitalisation.

Unfortunately few trials reported on the secondary outcomes that we planned to look at, and as with the primary outcome, the results of these analyses should be interpreted with caution, due to the possibility of outcome reporting bias. For measures of function, only one trial presented results that could be used in a meta-analysis. Multiple scales were used for the same outcome, and there is no agreement currently on how comparisons can be made between these scales for people suffering from bipolar disorder. Although we aimed to look at outcomes such as measures of satisfaction with the intervention, patient empowerment and quality of life, none of the trials reported on these outcomes. There was inconsistency on how medication use were reported, and hence a meta-analysis was not attempted.

In the RCTs reporting the primary outcome, the EWS intervention was delivered to participants only, except in Miklowitz 2003 where the carer was also included. The EWS intervention was delivered in groups (Colom 2003c; Colom 2003b; Miklowitz 2003) and individually (Lam 2005; Perry 1999; Scott 2006) over 12 sessions or more, except for one trial (Van Gent 1991). Perry 1999 was the only trial that used therapists with little previous experience to deliver the intervention. Therefore, successful EWS interventions seem to require around 12 sessions of therapist time and involve therapists of high competency. On this basis, EWS interventions for bipolar disorder may be expensive, although there appears to be a cost offset from reduced hospitalisation and improvements in social function, including patients returning to work. The one EWS intervention that used a less experienced and, therefore, less expensive therapist only showed a benefit against manic type recurrences and function, without any effect against depressive type recurrence. The relative cost-effectiveness of interventions involving more experienced versus less experienced therapists is a topic for further research.

\section{AUTHORS' CONCLUSIONS}

\section{Implications for practice}

Though data were obtained from a limited number of relevant trials, the results suggests psychological interventions incorporating EWS may be clinically effective in reducing relapse and hospitalisation, and possibly on function. EWS interventions had no impact on depressive and manic symptoms. The metaanalysis revealed an effect of EWS interventions on hospitalisation that was not previously well established. However, nearly half the identified RCTs did not report the primary outcome measure, so there may be a problem with selective reporting against negative outcomes. In general these trials had interventions delivered by therapists with some experience of both psychological intervention and bipolar disorder. An average of about twelve sessions of an hour long duration was used. The only exception to this was Perry 1999, which used a therapist with little previous experience.

Most health services in most countries could not accommodate EWS interventions within their usual treatment plans because of the way services are constructed currently and/or a shortage of staff trained to deliver EWS interventions. However, when psychological interventions for bipolar disorder can be purchased, the evidence in the meta-analysis favours interventions that incorporate the assessment and management of EWS. The cost offset of the EWS interventions through their effectiveness on both hospitalisation and social function including work could mean that EWS interventions for bipolar disorder may be cost effective and worth purchasing. The means by which EWS interventions could be efficiently delivered within existing health service systems is not clearly established.

\section{Implications for research}

Research into psychological interventions targeted at preventing recurrence should measure and report time to all bipolar recurrence, time to manic and depressive type recurrences, because these are the target of the intervention, and therefore should be reported as the primary outcome variables. The optimal service delivery of EWS interventions for bipolar disorder in terms of clinical and cost effectiveness and acceptability to service users requires exploration in research. At present, people with bipolar disorder tend to access many different types of service rather than services dedicated to bipolar disorder. EWS interventions may be effective for other patient groups as well; if so, then service delivery of EWS interventions might be efficiently targeted at a wide group of patients, and are more likely to become part of routine care. Another area that needs attention in future research is whether EWS interventions can be usefully applied to patients with bipolar disorder who have had many previous bipolar episodes or those who have just recently remitted from an acute bipolar episode.

\section{ACKNOWLEDGEMENTS}

We wish to acknowledge the contribution of the CCDAN editorial base in helping to devise the protocol and in particular the search strategy. We also wish to acknowledge Mersey Care NHS Trust who provided the funding that supported the systematic review and Professor Max Marshall who provided helpful advice at the outset on the design of the systematic review. 


\section{R E F E R E N C E S}

\section{References to studies included in this review}

Colom 2003b \{published data only\}

* Colom F, Vieta E, Reinares M, Martinez-Aran A, Torrent C, Goikolea JM, et al. Psychoeducation efficacy in Bipolar disorders : Beyond compliance enhancement. Journal of clinical psychiatry 2003;64(9):1101-5.

Colom 2003c \{published data only\}

* Colom F, Vieta E, Martinez-Aran A, Reinares M, Goikolea JM, Benabarre $A$, et al. A randomised trial on the efficacy of group psychoeducation in the prophylaxis of recurrences in Bipolar patients whose disease is in remission. Archives of General Psychiatry 2003;60:402-7.

\section{Lam 2000 \{published data only\}}

* Lam DH, Bright J, Jones S, Hayward P, Schuck N, Chisholm D, et al. Cognitive therapy for Bipolar Illness - A pilot study of relapse prevention. Cognitive Therapy and Research 2000;24(5):503-20.

\section{Lam 2005 \{published data only\}}

* Lam DH, Hayward P, Watkins ER, Wright K, Sham P. Relapse prevention in patients with bipolar disorder: Cognitive therapy outcome after 2 years. American Journal of Psychiatry 2005;162:324-9.

Lam DH, Watkins ER, Wright K, Kerr N, Parr-Davis G, Sham P. A randomised controlled study of cognitive therapy for relapse prevention for bipolar disorder. Archives of General Psychiatry 2003;60:145-52.

\section{Meyer 2003a \{published data only\}}

Meyer TD, Hautzinger M. A randomised controlled trial of cognitive behaviour therapy and supportive therapy for bipolar disorders. Bipolar Disorders 2003;5(1):135.

\section{Miklowitz 2003 \{published data only\}}

Miklowitz DJ, Simoneau TL, George JA, Richards JA, Kalbag A, Sachs-Ericsson N, et al. Family-focused treatment of Bipolar disorder : 1-year effects of a psychoeducational program in conjunction with pharmacotherapy. Biological Psychiatry 2000;48:582-92.

Miklowitz DJ, George EL, Richards JA, Simoneau TL, Suddath RL. A randomised study of family -focused psychoeducation and pharmacotherapy in the outpatient management of bipolar disorder. Archives of General Psychiatry 2003;60:904-12.

Simoneau TL, Miklowitz DJ, Richards JA, Saleem R, George EL. Bipolar Disorder and family communication : Effects of a psychoeducational treatment program. Journal of Abnormal Psychology 1999;108(4):588-97.

\section{Perry 1999 \{published data only\}}

* Perry A, Tarrier N, Morriss R, McCarthy E, Limb K. Randomised controlled trial of efficacy of teaching patients with Bipolar disorder to identify early symptoms of relapse and obtain treatment. BMJ 1999;318:149-53.
Scott 2001 \{published data only\}

Scott J, Garland A, Moorhead S. A pilot study of cognitive therapy for bipolar disorders. International Journal of Neuropsychopharmacology 2000;3(1):10.

* Scott J, Garland A, Moorhead S. A pilot study of cognitive therapy in bipolar disorders. Psychological Medicine 2001;31:459-67.

\section{Scott 2006 \{published data only\}}

* Scott J, Paykel E, Morriss R, Bentall R, Kinderman P, Johnson T, et al. Cognitive behaviour therapy for severe and recurrent Bipolar disorders: a randomised controlled trial. British Journal of Psychiatry 2006;188:313-20.

Simon 2004 \{published data only\}

* Simon GE, Ludman EJ, Unutzer J, Bauer MS, Operskalski B, Rutter C. Randomised trial of a population-based care program for people with bipolar disorder. Psychological Medicine 2004;34:1-12.

Van Gent 1991 \{published data only\}

* Van Gent EM, Zwart FM. Psychoeducation of partners of Bipolar-manic patients. Journal of Affective Disorders 1991;21:15-8.

\section{References to studies excluded from this review}

Beardslee 1992 \{published data only\}

* Beardslee W, Hoke L, Wheelock I, Rothberg P, Van De Velde P, Swatling S. Initial findings on preventive intervention for families with parental affective disorders. American Journal of Psychiatry 1992;149(10):1335-40.

Beardslee 1993 \{published data only\}

* Beardslee WR, Salt P, Porterfield K, Rothberg PC, van de Velde P, Swatling S, et al. Comparison of preventive interventions for families with parental affective disorder. Journal of the American Academy of Child and Adolescent Psychiatry 1993;32(2):254-63.

Becker 1998 \{published data only\}

* Becker DR, Drake RE, Bond GR, Xie H, Dain BJ, Harrison K. Job terminations among persons with severe mental illness participating in supported employment. Community Mental Health Journal 1998;34(1):71-82.

Burns 1994 \{published data only\}

* Burns DD, Sayers SL, Moras K. Intimate relationships and depression : Is there a causal connection. Journal of Consulting and Clinical Psychology 1994;62(5):1033-43.

Clarkin 1998 \{published data only\}

* Clarkin JF, Carpenter D, Hull J, Wilner P, Glick I. Effects of psychoeducational intervention for married patients with Bipolar disorder and their spouses. Psychiatric Services 1998;49:531-3. 


\section{Cochran 1984 \{published data only\}}

* Cochran SD. Preventing medical noncompliance in the outpatient treatment of Bipolar affective disorders. Journal of Consulting and Clinical Psychology 1984;52(5):873-8.

\section{Draine 1994 \{published data only\}}

* Draine J, Solomon P. Explaining attitudes toward medication compliance among seriously mentally ill population. Journal of Nervous and Mental Disease 1994;182(1):50-4.

\section{Drake 1996 \{published data only\}}

* Drake RE, McHugo GJ, Becker DR, Anthony WA, Clarke RE. The New Hampshire study of supported employement for people with severe mental illness. Journal of consulting and clinical psychology 1996;64(2):391-6.

\section{Elixhauser 1990 \{published data only\}}

* Elixhauser A, Eisen SA, Romeis JC, Homan SM. The effects of monitoring and feedback on compliance. Medical Care 1990;28(10):882-3.

Frank 2005 \{published data only\}

* Frank E, Kupfer DJ, Thase ME, Mallinger AG, Swartz HA, Fagiolini AM, et al. Two-Year Outcomes for Interpersonal and Social Rhythm Therapy in Individuals With Bipolar I Disorder. Archives of General Psychiatry 2005;62:996-1004.

Glick 1993 \{published data only\}

* Glick ID, Clarkin JF, Haas GL, Spencer JH. Clinical significance of inpatient family intervention: conclusions from a clinical trial. Hospital and Community Psychiatry 1993;44(9):869-73.

Honig 1997 \{published data only\}

* Honig A, Hofman A, Rozendaal N, Dingemans P. Psychoeducation in bipolar disorder: Effect on expressed emotion. Psychiatry Research 1997;72(1):17-22.

\section{Kochman 2003 \{published data only\}}

* Kochman FJ, Hantouche EG, Meynard JA, Bayart D. A randomised trial of an interpersonal/cognitive behaviour intervention for preventing Bipolar disorder in depressed adolescents. Bipolar Disorder. 2003; Vol. 5, issue 1:113.

\section{Kornblith 1983 \{published data only\}}

* Kornblith SJ, Rehm LP, O'Hara MW, Lamparski DM. The contribution of self reinforcement training and behavioural assignments to the efficacy of self control therapy for depression. Cognitive Therapy and Research 1983;7(6):499-528.

\section{Lapidus 2001 \{published data only\}}

* Lapidus LB, Shin SK, Hutton EM. An evaluation of six week intervention designed to facilitate coping with psychological stress. Journal of Clinical Psychology 2001;57(12):1381-401.

Miller 2004 \{published data only\}

* Miller IW, Solomon DA, Ryan CE, Keitner GI. Does adjunctive family therapy enhance recovery from Bipolar I mood episodes?. Journal of Affective Disorders 2004;82(3):431-6.
Monti 1980 \{published data only\}

* Monti PM, Curran JP, Corriveau DP, Delancey AL, Hagerman SM. Effects of social skills training groups and sensitivity training groups with psychiatric patients. Journal of Consulting and Clinical Psychology 1980;48(2):241-8.

O'Donnell 1999 \{published data only\}

* O'Donnell M, Parker G, Proberts M, Matthews R, Fisher D, Johnson B, et al. A study of client focused case management and consumer advocacy: the community and consumer service project. Australian and New Zealand Journal of Psychiatry 1999;33(5):684-93.

Rea 2003 \{published data only\}

* Rea MM, Tompson MC, Miklowitz DJ, Goldstein MJ, Hwang S, Mintz J. Family focused treatment versus individual treatment for Bipolar disorder: Results of a randomised clinical trial. Journal of Consulting and Clinical Psychology 2003;71(3):482-92.

Souza 2003 \{published data only\}

* Souza RD, Keks N, Rich D, Diamond I, Godfrey K. An open randomised control study using a spiritually augmented cognitive behaviour therapy for demoralization and treatment adherence in patients with Bipolar 1 depression. Bipolar Disorder. 2003; Vol. 5, issue 1:51.

Tompson 2000 \{published data only\}

* Tompson MC, Rea MM, Goldstein MJ, Miklowitz DJ, Weisman AG. Difficulty in implementing a family intervention for bipolar disorder : the predictive role of patient and family attributes. Family Process 2000;39(1):105-20.

Tyrer 1992 \{published data only\}

* Merson S, Tyrer P, Onyett S, Lack S, Birkett P, Lynch S, et al. Early intervention in psychiatric emergencies : a controlled clinical trial. Lancet 1992;339(8805):1311-4.

\section{Warning 1995 \{published data only\}}

* Warning EM, Chamberlin CH, Carver CM, Stalker CA, Schaefer B. A pilot study of marital therapy as a treatment for depression. American Journal of Family Therapy 1995;23(1):3-10.

Weiss 2000 \{published data only\}

* Weiss RD, Griffin ML, Greenfield SF, Najavits LM, Wyner D, Soto JA, et al. Group therapy for patients with Bipolar disorder and substance dependence:results of a pilot study. Journal of Clinical Psychiatry 2000;61(5):361-7.

Wolk 1997 \{published data only\}

* Wolk R, Goldfarb Al. The response to group psychotherapy of aged recent admissions compared with long term mental hospital patients. American Journal of Psychiatry 1967;123(10):1251-7.

\section{References to studies awaiting assessment}

Ball \{published data only\}

Ball JR, Mitchell PB, Corry JC, Skillecorn A, Smith M, Malhi GS. $A$ randomised controlled trial of cognitive therapy for bipolar 
disorder : focus on long-term change. Journal of Clinical Psychiatry 2006;67(2):277-86.

\section{References to ongoing studies}

Meyer 2003 \{unpublished data only\}

Meyer TD, Hautzinger M. A randomised controlled trial of cognitive behaviour therapy and supportive therapy for bipolar disorders. Bipolar Disorders. 2003; Vol. 5, issue 1:135.

\section{Additional references}

\section{Altman 1992}

Altman ES, Rea MM, Mintz J, Miklowitz DJ, Goldstein MJ, Hwang S. Prodromal symptoms and signs of bipolar relapse: a report based on prospectively collected data. Psychiatric Research 1992;27(1):245-8.

\section{Altman 1997}

Altman EG, Hedeker D, Peterson JL, Davis JM. The Altman SelfRating Mania Scale. Biological Psychiatry 1997;42(10):948-55.

\section{APA 1995}

American Psychiatric Association. Diagnostic and Statistical Manual of Mental Disorders, (DSM-IV). 4th Edition. Washington, DC: American Psychiatric Association, 1995.

\section{Ball 2003}

Ball J, Mitchell P, Malhi G, Skillecorn A, Smith M. Schema focused cognitive therapy for bipolar disorder : reducing vulnerability to relapse through attitudinal change.. Australian and New Zealand Journal of Psychiatry 2003;37(1):41-8.

\section{Bauer 1991}

Bauer MS, Crits-Ctristoph P, Ball WA, Dewees, McAllister T, Alahi $P$, et al. Independent assessment of manic and depressive symptoms by self-rating. Scale characteristics and implications for the study of mania. Archives of General Psychiatry 1991;48(9):807-12.

\section{Bech 1978}

Bech P, Rafaelsen OJ, Kramp P, Bolwig TG. Mania Rating Scale: Scale construction and interobserver agreement. Neuropharmacology 1978;17(6):430-1.

\section{Beck 1961}

Beck AT, Ward C, Mendelson M, Mock J, Erbaugh J. An inventory for measuring depression. Archives of General Psychiatry 1961;4:561-71.

\section{Birchwood 1989}

Birchwood M, Smith J, Macmillan F, Hogg B, Prasad R, Harvey C, et al. Predicting relapse in schizophrenia: the development and implementation of an early signs monitoring system using patients and families as observers, a preliminary investigation. Psychological Medicine 1989;19(3):649-56.

\section{Bowden 2000}

Bowden C, Calabrese JR, McElroy SL, Gyulai L, Wassef A, Petty F, et al. A randomized, placebo-controlled 12 month trial of divalproex and lithium in treatment of out-patients with bipolar 1 disorder. Divalproex Maintenance Study Group. Archives of General Psychiatry 2000;57(5):481-9.

\section{Burgess 2003}

Burgess S, Geddes J, Hawton K, Townsend E, Jamison K, Goodwin G. Lithium for maintenance treatment of mood disorders. Cochrane Database of Systematic Reviews 2003, Issue 2.

\section{Bustillo 1995}

Bustillo J, Buchanan RW, Carpenter T. Prodromal symptoms vs. early warning signs and clinical action in schizophrenia. Schizophrenia Bulletin 1995;21(4):553-9.

\section{Coryell 1989}

Coryell W, Keller M, Endicott J, Andreasen N, Clayton P, Hirschfeld R. Bipolar Il illness: course and outcome over a five year period. Psychological Medicine 1989;19(1):129-41.

\section{Denicoff 1999}

Denicoff KD, Alis SO, Mirsky AF, Smith-Jackson EE, Leverich GS, Duncan $C$, et al. Relationship between prior course of illness and neuropsychological functioning in patients with bipolar disorder. Journal of Affective Disorders 1999;56(1):67-73.

\section{EuroQol Group 1990}

EuroQol Group. Euroqol EQ-5D - A new measurement of quality of life. Health Policy 1990; Vol. 16.

\section{Gitlin 1995}

Gitlin MJ, Swendsen J, Heller TL, Hammen C. Relapse and impairment in bipolar disorder. American Journal of Psychiatry 1995;152(11):1635-40.

\section{Goodwin 1990}

Goodwin FK, Jamieson KR. Manic-depressive illness. New York, NY: Oxford University Press, 1990.

\section{Hahn 2000}

Hahn S, Williamson PR, Hutton JL, Garner P, Flynn EV. Assessing the potential for bias in meta-analysis due to selective reporting of subgroup analyses within studies. Statistics in Medicine 2000;19(24):3325-36.

\section{Hamilton 1960}

Hamilton M. A rating scale for depression. Journal of Neurology, Neurosurgery and Psychiatry 1960;23:56-61.

\section{Hammen 1997}

Hammen C, Gitlin M. Stress reactivity in bipolar patients and its relation to prior history of disorder. American Journal of Psychiatry 1997;154:856-7.

\section{Harrow 1990}

Harrow M, Goldberg JF, Grossman LS, Meltzer HY. Outcome in manic disorders. A naturalistic follow-up study. Archives of General Psychiatry 1990;47(7):665-71. 


\section{Hill 1996}

Hill RG, Shepherd G, Hardy P. A survey of the Manic Depression Fellowship. London: Sainsbury Centre for Mental Health, 1996.

\section{Hurry 1983}

Hurry J, Sturt E, Bebbington P, Tennant C. Socio-demographic associations with social disablement in a community sample. Social Psychiatry 1983;18(3):113-21.

\section{Hutton 2000}

Hutton JL, Williamson PR. Bias in meta-analysis due to outcome variable selection within studies. Applied Statistics 2000;49:359-70.

\section{Jacobson 1965}

Jacobson JE. The hypomanic alert: a program designed for greater therapeutic control. American Journal of Psychiatry 1965;122:295-9.

\section{Jones 2005}

Jones AP, Williamson PR, Whitehead A, Riley R. Meta-analysis of Longitudinal Data. Royal Statistical Society Annual Conference 2005. 2005

\section{Joyce 1985}

Joyce PR. Illness behaviour and rehospitalisation in bipolar affective disorder. Psychological Medicine 1985;15(3):521-5.

\section{Judd 2002}

Judd LL, Akiskal HS, Schlettler PJ, Endicott J, Maser J, Solomon DA, et al. The long-term natural history of the weekly symptomatic status of bipolar 1 disorder. Archives of General Psychiatry 2002;59(6):530-7.

\section{Keller 1987}

Keller MB, Lavori PW, Friedman B, Nielsen E, Endicott J, McDonald-Scott P, et al. The Longitudinal Interval Follow-up Evaluation: a comprehensive method for assessing outcome in prospective longitudinal studies. Archives of General Psychiatry 1987;44(6):540-8.

\section{Keller 1992}

Keller MB, Lavori PW, Kane JM, Gelenberg AJ, Rosenbaum JF, Walzer EA, et al. Subsyndromal symptoms in bipolar disorder: a comparison of standard and low serum levels of lithium. Archives of General Psychiatry 1992;49(5):371-6.

\section{Lam 1997}

Lam D, Wong G. Prodromes, coping strategies, insight and social functioning in bipolar affective disorders. Psychological Medicine 1997;27(5):1091-100.

\section{Lam 2003}

Lam DH, Watkins ER, Hayward P, Bright J, Wright K, Kerr N, et al. A randomised controlled study of cognitive therapy for relapse prevention for bipolar affective disorder: outcome of the first year. Archives of General Psychiatry 2003;60(2):145-52.

\section{Lish 1994}

Lish JD, Dime-Meenan S, Whybrow PC, Price RA, Hirschfeld RM. The National MDA Survey of bipolar members. Journal of Affective Disorders 1994;31(4):281-94.

\section{Miklowitz 2000}

Miklowitz DJ, Simoneau TL, George EL, Richards JA, Kalbag A Sachs-Ericsson N, et al. Family-focused treatment of Bipolar disorder: 1 year effects of a psychoeducational program in conjunction with pharmacotherapy. Biological psychiatry 2000;48:582-92.

\section{Molnar 1988}

Molnar G, Feeny M, Fava G. The duration and symptoms of bipolar prodromes. American Journal of Psychiatry 1988;145(12):1575-8.

\section{Montgomery 1979}

Montgomery SA, Asberg M. A new depression rating scale designed to be sensitive to change. British Journal of Psychiatry 1979;134:382-9.

\section{Morriss 2002}

Morriss R, Marshall M, Harris A. Bipolar affective disorder - left out in the cold. BMJ 2002;324(7329):61-2.

\section{Morriss 2004}

Morriss R. Teaching bipolar affective disorder patients how to recognize and manage early signs of relapse. Advances in Psychiatric Treatment 2004;10(1):18-26.

\section{Mueser 2002}

Mueser KT, Corrigan PW, Hilton DW, Tanzman B, Schaub A, Gingerich $S$, et al. Illness management and recovery: A review of the research. Psychiatric Services 2002;53(10):1272-84.

\section{O'Connell 1991}

O'Connell RA, Mayo JA, Flatow L, Cuthbertson B, O'Brien BE. Outcome of bipolar disorder on long-term treatment with lithium. British Journal of Psychiatry 1991;159:123-9.

\section{Ozer 2002}

Ozer S, Ulusahin A, Batur S, Kabakci E, Saka MC. Outcome measures of interepisode bipolar patients in a Turkish sample. Social Psychiatry and Psychiatric Epidemiology 2002;37(1):31-7.

\section{Parmar 1998}

Parmar MK, Torri V, Stewart L. Extracting summary statistics to perform meta-analyses of the published literature for survival endpoints. Statistics in Medicine 1998;17(24):2815-34.

\section{Perry 1995}

Perry A, Tarrier N, Morriss R. Identification of prodromal signs and symptoms and early intervention in manic depressive psychosis patients: a case example. Behavioural and Cognitive Psychotherapy 1995;23(4):399-409.

\section{Robins 1984}

Robins LN, Helzer JE, Weissman MM, Orvaschel H, Gruenberg E, Burke JD Jr, et al. Lifetime prevalence of specific psychiatric 
disorders in three sites. Archives of General Psychiatry 1984;41(10):949-58.

\section{Scott 2006a}

Scott J, Colom F, Vieta E. Psychological therapies in bipolar disorders: a meta-analysis. International Journal of Neuropsychopharmacology 2006.

\section{Simoneau 1999}

Simoneau TL, Miklowitz DJ, Richards JA, Saleem R, George EL. Bipolar Disorder and family communication: Effects of a psychoeducational treatment program. Journal of Abnormal Psychology 1999;108(4):588-97.

\section{Smith 1992}

Smith J, Tarrier N. Prodromal symptoms in manic depressive psychosis. Social Psychiatry and Psychiatric Epidemiology 1992;27(5):245-8.

\section{ten Have 2002}

ten Have M, Vollebergh W, Bijl R, Nolen WA. Bipolar disorder in the general population in the Netherlands ( prevalance, consequences and care utilisation ): results from The Netherlands Mental health survey and incidence study (NEMESIS). Journal of Affective Disorders 2002;68(2-3):203-13.

\section{CHARACTERISTICS OF STUDIES}

Characteristics of included studies [ordered by study ID]

\section{Tohen 1990}

Tohen M, Waternaux GM, Tsuang MT. Outcome in mania: a 4year prospective follow-up of 75 patients utilising survival analysis. Archives of General Psychiatry 1990;47(12):1106-11.

\section{Williamson 2005}

Wiiliamson PR, Gamble C, Altman DG, Hutton JL. Outcome selection bias in meta-analysis. Statistical Methods in Medical Research 2005;14:515-24.

\section{Williamson 2005 a}

Williamson PR, Gamble C. Identification and impact of outcome selection bias in meta-analysis. Statistics in Medicine 2005;24:1547-61.

\section{Young 1978}

Young RC, Biggs VT, Ziegler VE, Meyer DA. A rating scale for mania: reliability, validity and sensitivity. British Journal of Psychiatry 1978;133:429-35.

\section{Zigmond 1983}

Zigmond AS, Snaith RP. The Hospital Anxiety and Depression Scale. Acta Psychiatrica Scandinavica 1983;67(6):361-70.

* Indicates the major publication for the study

Colom 2003b

$\begin{array}{ll}\text { Methods } & \text { Allocation : Randomised } \\ & \text { Blinding : None, Outcome assessor blind } \\ & \text { Duration : } 20 \text { weeks treatment phase, } 24 \text { months follow up }\end{array}$

$\begin{array}{ll}\text { Participants } & \text { Diagnosis : Bipolar } 1 \text { (DSM1V) based on opinion of senior psychiatrist } \\ & \text { Age }-18 \text { to } 65, \text { mean(sd) } 34.5(7.8) \text { in treatment and } 35.4(10.9) \text { in control } \\ \text { Sex } 64 \% \text { females in control , 60\% females in treatment group } \\ \text { History : Excludes axis } 1 \text { comorbidity. } \\ \text { Number of previous episodes (7-11) } \\ \text { Setting : Secondary care }\end{array}$

Interventions TAU N = 25. seen by their psychiatrist every four weeks. The group met every week in group of eight to twelve patients without any special instruction from same therapists.

TAU + Psychoeducation ( reports as 20 sessions of 90 minutes each. programme delivered by two experienced psychologists ) $\mathrm{N}=25$.

Outcomes Time to any reccurrence, manic reccurence, mixed recurence, depressive recurrence.
Percentage of people hospitalised.

Notes

\section{Risk of bias}

\begin{tabular}{lll}
\hline Bias & Authors' judgement & Support for judgement \\
\hline Allocation concealment? & Low risk & A - Adequate \\
\hline
\end{tabular}


Colom 2003c

$\begin{array}{ll}\text { Methods } & \text { Allocation : Randomised } \\ & \text { Blinding : None, Outcome assessor blind } \\ & \text { Duration : } 21 \text { weeks treatment phase, } 24 \text { months follow up }\end{array}$

\begin{tabular}{ll}
\hline Participants & Diagnosis : Bipolar 1 and 11 (DSM1V) based on opinion of senior psychiatrist \\
& Age -18 to 65 \\
& Sex $-63 \%$ females in control, $63 \%$ female in tretment group \\
& History : Excludes axis 1 comorbidity. \\
& Number of previous episodes (7-11) \\
& Setting : Secondary care
\end{tabular}

Interventions TAU N = 60. Patients seen by two psychiatrists every four weeks. Control group met every week in groups of eight to twelve without special instructions from the same therapist.

TAU + Psychoeducation ( 21 sessions of 90 minutes . conducted by two experienced psychologist ) $\mathrm{N}=$ 60

\begin{tabular}{|c|c|c|}
\hline Outcomes & $\begin{array}{l}\text { Time to any recurrenc } \\
\text { Percentage of people }\end{array}$ & $\begin{array}{l}\text { manic recurence, mixed recurence, depressive recurrence. } \\
\text { ospitalised. }\end{array}$ \\
\hline \multicolumn{3}{|l|}{ Notes } \\
\hline \multicolumn{3}{|l|}{ Risk of bias } \\
\hline Bias & Authors' judgement & Support for judgement \\
\hline Allocation concealment? & Low risk & A - Adequate \\
\hline
\end{tabular}

Lam 2000

$\begin{array}{ll}\text { Methods } & \text { Allocation : Randomised } \\ & \text { Blinding : None, Outcome assessor blind } \\ & \text { Duration : Therapy for six months and } 12 \text { months follow up }\end{array}$

\begin{tabular}{ll}
\hline Participants & Diagnosis : Bipolar 1 (DSM1V), no more details given . \\
& Age -18 to 65 , mean(sd) $39.0(10.9) y r s$ \\
& Sex ( F :M ) $12: 13$ \\
& History : Excludes axis 1 comorbidity. \\
& Number of previous episodes (7-11) \\
& Setting : Secondary care
\end{tabular}

Interventions TAU N $=12$ delivered by multidisciplinary team .

TAU + Psychoeducation ( reports as 12 to 20 sessions within six months. Therapists were clinical psychologists with a minimum of six years postqualification experience ) $\mathrm{N}=13$

Mean number of bipolar episodes, depressed episode, hypomanic episode and total bipolar episodes
(these couldnt be used )HDRS score at 12 months
BDI score at 12 months
Measure of functioning

\section{Notes}

\section{Risk of bias}


Lam 2000 (Continued)

\begin{tabular}{lll} 
Bias & Authors' judgement & Support for judgement \\
\hline Allocation concealment? & Unclear risk & B - Unclear \\
\hline
\end{tabular}

Lam 2005

\begin{tabular}{ll}
\hline Methods & Allocation : Randomised \\
& Blinding : None, Outcome assessor blind \\
& Duration : 12 to 18 sessions in first six months and two booster sessions in second six months . \\
& 24 months follow up
\end{tabular}

\begin{tabular}{ll}
\hline Participants & Diagnosis : Bipolar 1 (DSM1V) based on SCID by research assisstant \\
Age -18 to 70, mean(sd) $46.4(12.1)$ in treatment and $41.5(10.8)$ in control \\
Sex ( F :M ) 28:51 in control , 30:52 in treatment group \\
History : Excludes axis 1 comorbidity. \\
Number of previous episodes (7-11) \\
Setting : Secondary care
\end{tabular}

\begin{tabular}{ll}
\hline Interventions & TAU N $=52$ \\
& $\begin{array}{l}\text { TAU + Psychoeducation ( } 12 \text { to } 18 \text { sessions. The therapists were clinical psychologists with a minimum } \\
\text { five years post qualification experience. ) } \mathrm{N}=51\end{array}$ \\
\hline Outcomes & $\begin{array}{l}\text { Time to any reccurrence,manic reccurence depressive recurrence. } \\
\text { Measure of functioning }\end{array}$ \\
\hline Notes &
\end{tabular}

\section{Risk of bias}

\begin{tabular}{lll}
\hline Bias & Authors' judgement & Support for judgement \\
\hline Allocation concealment? & Low risk & A-Adequate \\
\hline
\end{tabular}

Meyer 2003a

\begin{tabular}{ll}
\hline Methods & See table under ongoing studies \\
\hline Participants & See table under ongoing studies \\
\hline Interventions & See table under ongoing studies \\
\hline Outcomes & See table under ongoing studies \\
\hline Notes & \\
\hline Risk of bias & Authors' judgement $\quad$ Support for judgement \\
\hline Bias & Unclear risk $\quad$ B - Unclear \\
\hline Allocation concealment? & \\
\hline
\end{tabular}


Miklowitz 2003

\begin{tabular}{ll}
\hline Methods & Allocation : Randomised (2:1) \\
& Blinding : None, Outcome assessor blind \\
& Duration : nine months treatment, 24 months follow up
\end{tabular}

\begin{tabular}{ll}
\hline Participants & Diagnosis : Bipolar 1 (DSM111-R) using structured psychiatric interview by research assisstant \\
& Age - 18 to 60, mean(sd) 35.7(9.2)yrs in treatment group and 35.6(10.6) in control group. \\
Sex ( F :M ) 18:13 in treatment group and 46:24 in control group. \\
History : axis 1 comorbidity - not stated. \\
Number of previous episodes (1-6) \\
Setting : Secondary care \\
TAU N $=70$. This group received two sessions of family education in addition to clinical input / crisis \\
management. \\
TAU + Psychoeducation N $=31$ \\
21 sessions of an hour each
\end{tabular}

Outcomes

Time to any reccurrence. Total number of hospitalization but data couldnt be used as there was no separate data on control and treatment.

Notes

\section{Risk of bias}

\begin{tabular}{lll}
\hline Bias & Authors' judgement & Support for judgement \\
\hline Allocation concealment? & Unclear risk & B - Unclear \\
\hline
\end{tabular}

Perry 1999

$\begin{array}{ll}\text { Methods } & \text { Allocation : Randomised } \\ & \text { Blinding : None, Outcome assessor blind } \\ & \text { Duration : } 18 \text { months follow up }\end{array}$

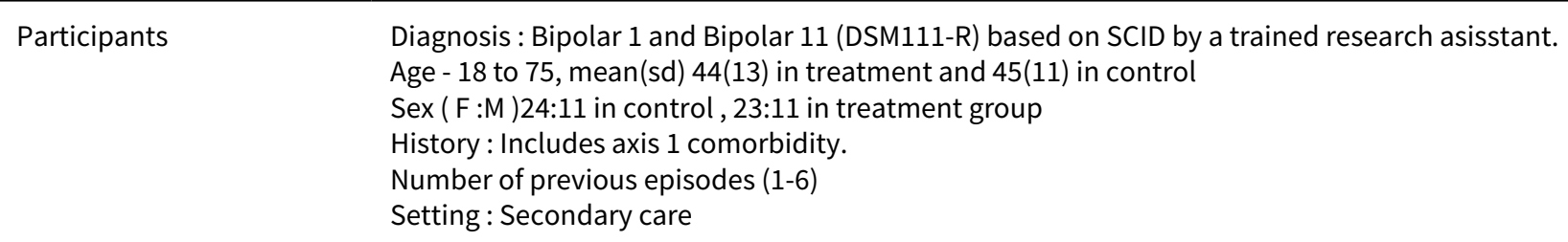

\begin{tabular}{lll}
\hline Bias & Authors' judgement & Support for judgement \\
\hline Allocation concealment? & Low risk & A - Adequate \\
\hline \hline
\end{tabular}


Scott 2001

$\begin{array}{ll}\text { Methods } & \text { Allocation : Randomised } \\ & \text { Blinding : None, Outcome assessor blinding unclear } \\ & \text { Duration : six months treatment. } 18 \text { months follow up }\end{array}$

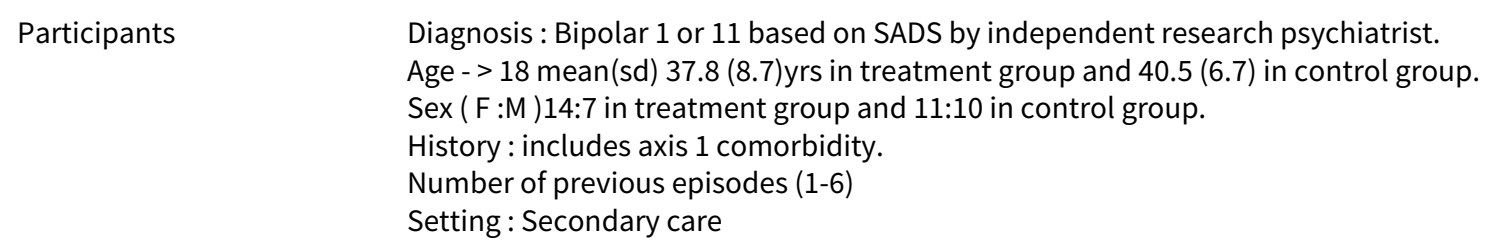

Participants

Diagnosis : Bipolar 1 or 11 based on SADS by independent research psychiatrist.

Age - > 18 mean(sd) 37.8 (8.7)yrs in treatment group and 40.5 (6.7) in control group.

Sex ( F :M ) 14:7 in treatment group and 11:10 in control group.

History : includes axis 1 comorbidity.

Number of previous episodes (1-6)

Setting : Secondary care

\begin{tabular}{|c|c|c|}
\hline Interventions & \multicolumn{2}{|c|}{$\begin{array}{l}\text { TAU N }=21 \\
\text { TAU + Psychoeducation ( } 14 \text { sessions of } 45 \text { minutes each by two experienced therapists. ) } N=21\end{array}$} \\
\hline Outcomes & \multicolumn{2}{|c|}{$\begin{array}{l}\text { GAF , ISS, WASA, BDI, Number of patients relapsed. } \\
\text { None used. }\end{array}$} \\
\hline \multicolumn{3}{|l|}{ Notes } \\
\hline \multicolumn{3}{|l|}{ Risk of bias } \\
\hline Bias & Authors' judgement & Support for judgement \\
\hline Allocation concealment? & Unclear risk & B - Unclear \\
\hline
\end{tabular}

\section{Scott 2006}

\begin{tabular}{|c|c|}
\hline Methods & $\begin{array}{l}\text { Allocation : Randomised } \\
\text { Blinding : None, Outcome assessor blind } \\
\text { Duration : held weekly for } 15 \text { weeks and then with gradually decreasing frequency until } 26 \text { weeks. } \\
18 \text { months follow up }\end{array}$ \\
\hline Participants & $\begin{array}{l}\text { Diagnosis : Bipolar } 1 \text { and Bipolar } 11 \text { (DSM1V) based on SCID } \\
\text { Age - >18 mean(sd) } 42.7(11.4) \text { in control and } 39.7(10.3) \text { in treatment } \\
\text { Sex ( F :M ) 85:40 in treatment, } 79: 47 \text { in control group } \\
\text { History : Includes axis } 1 \text { comorbidity. } \\
\text { Setting : Secondary care }\end{array}$ \\
\hline Interventions & $\begin{array}{l}\text { TAU N }=126 \\
\text { TAU + Psychoeducation ( reports as } 20 \text { sessions. Delivered by accredited therapists. ) } N=127\end{array}$ \\
\hline Outcomes & $\begin{array}{l}\text { Time to any reccurence, manic reccurence depressive recurrence. } \\
\text { Measure of functioning }\end{array}$ \\
\hline \multicolumn{2}{|l|}{ Notes } \\
\hline \multicolumn{2}{|l|}{ Risk of bias } \\
\hline Bias & Authors' judgement Support for judgement \\
\hline Allocation concealment? & A - Adequate \\
\hline
\end{tabular}


Simon 2004

\begin{tabular}{|c|c|}
\hline Methods & $\begin{array}{l}\text { Allocation : Randomised } \\
\text { Blinding : None, Outcome assessor blind } \\
\text { Duration : } 12 \text { months follow up }\end{array}$ \\
\hline Participants & $\begin{array}{l}\text { Diagnosis : Bipolar } 1 \text { and } 11 \text { (DSM1V) using SCID and record review by senior psychiatrist. } \\
\text { Age - > } 18 \text { mean(sd) } 44.1(13.4) y r s \text { in treatment group and } 44.3(12.9) \text { in control group. } \\
\text { Sex ( F :M ) 144:212 in treatment group and 157:229 in control group. } \\
\text { History: includes axis } 1 \text { comorbidity. } \\
\text { Number of previous episodes (not stated) } \\
\text { Setting: Secondary care }\end{array}$ \\
\hline Interventions & $\begin{array}{l}\text { TAU N }=229 \\
\text { TAU + Psychoeducation ( Five weekly group sessions followed by twice monthly sessions for } 12 \\
\text { months ) } N=212\end{array}$ \\
\hline Outcomes & Percentage of people hospitalised. \\
\hline \multicolumn{2}{|l|}{ Notes } \\
\hline \multicolumn{2}{|l|}{ Risk of bias } \\
\hline Bias & Support for judgement \\
\hline Allocation concealment? & A - Adequate \\
\hline
\end{tabular}

\section{Van Gent 1991}

$\begin{array}{ll}\text { Methods } & \text { Allocation : Randomised } \\ & \text { Blinding : None } \\ & \text { Duration : } 6 \text { months follow up }\end{array}$

\begin{tabular}{|c|c|}
\hline Participants & $\begin{array}{l}\text { Diagnosis : Bipolar patients (DSM } 111 \mathrm{R} \text { ) based on opinion of two independent psychiatrist. } \\
\text { Age - mean(sd) } 44(11) \text { yrs in treatment group and } 55(10) \text { in control group. } \\
\text { Sex ( F :M ) - not stated. } \\
\text { History : axis } 1 \text { comorbidity -not stated. } \\
\text { Number of previous episodes - not stated } \\
\text { Setting : Secondary care }\end{array}$ \\
\hline
\end{tabular}

\begin{tabular}{|c|c|}
\hline Interventions & $\begin{array}{l}\text { TAU N }=12 \\
\text { TAU + Psychoeducation ( reports as five sessions ) } N=14\end{array}$ \\
\hline Outcomes & None used \\
\hline \multicolumn{2}{|l|}{ Notes } \\
\hline \multicolumn{2}{|l|}{ Risk of bias } \\
\hline Bias & Support for judgement \\
\hline Allocation concealment? & Unclear risk \\
\hline
\end{tabular}


Characteristics of excluded studies [ordered by study ID]

\begin{tabular}{|c|c|}
\hline Study & Reason for exclusion \\
\hline Beardslee 1992 & Interventions did not include early signs of recurrence \\
\hline Beardslee 1993 & Duplicate study (same as Beardslee 1992) \\
\hline Becker 1998 & Not RCT \\
\hline Burns 1994 & Population did not include adults with bipolar disorder \\
\hline Clarkin 1998 & Duplicate study (same as Glick 1993) \\
\hline Cochran 1984 & Interventions did not include early signs of recurrence \\
\hline Draine 1994 & Population did not include adults with bipolar disorder \\
\hline Drake 1996 & Intervention did not include early signs of recurrence \\
\hline Elixhauser 1990 & $\begin{array}{l}\text { Population did not include adults with bipolar disorder and intervention did not include early signs } \\
\text { of recurrence }\end{array}$ \\
\hline Frank 2005 & $\begin{array}{l}\text { Both treatment groups received early warning sign intervention, which is an exclusion criterion in } \\
\text { this review. }\end{array}$ \\
\hline Glick 1993 & Intervention did not include early signs of recurrence \\
\hline Honig 1997 & Not RCT \\
\hline Kochman 2003 & Population did not include adults with diagnosis of bipolar disorder \\
\hline Kornblith 1983 & Population did not include adults with diagnosis of bipolar disorder \\
\hline Lapidus 2001 & Interventions did not include early signs of recurrence \\
\hline Miller 2004 & Interventions did not include early signs of recurrence \\
\hline Monti 1980 & $\begin{array}{l}\text { Population did not include adults with diagnosis of bipolar disorder and interventions did not in- } \\
\text { clude early signs of recurrence }\end{array}$ \\
\hline O'Donnell 1999 & Interventions did not include early signs of recurrence \\
\hline Rea 2003 & $\begin{array}{l}\text { Both control group and treatment group included early signs of recurrence as part of their inter- } \\
\text { vention. }\end{array}$ \\
\hline Souza 2003 & Intervention did not include early signs of recurrence \\
\hline Tompson 2000 & Not an RCT \\
\hline Tyrer 1992 & Population did not include people with early signs of recurrence \\
\hline Warning 1995 & Population did not include adults with diagnosis of bipolar disorder \\
\hline Weiss 2000 & Not RCT \\
\hline Wolk 1997 & Not RCT \\
\hline
\end{tabular}


Characteristics of ongoing studies [ordered by study ID]

Meyer 2003

\begin{tabular}{|c|c|}
\hline Trial name or title & Cognitive Behaviour Therapy and Supportive Therapy \\
\hline \multicolumn{2}{|l|}{ Methods } \\
\hline \multirow[t]{4}{*}{ Participants } & $\begin{array}{l}\text { Diagnosis : Bipolar } 1 \text { or } 11 \text { (DSM } 1 \mathrm{~V}, \mathrm{SCID}) \text { does not say who made the diagnosis. } \\
\text { Age : } 44.4(\mathrm{SD}==11) \text { in TAU + CBT and } 43.5((\mathrm{SD}=12.7) \text { in TAU. } \\
\text { Sex : } 47 \% \text { female in Treatment group and } 53 \% \text { in control } \\
\text { Unclear if axis } 1 \text { comorbidity was included or excluded. }\end{array}$ \\
\hline & Age :18 - 65 , Mean(sd) 44.4(11) in treatment group and 43.5(12.7) in control group \\
\hline & Sex $: 47.4 \%$ in treatment group and $52.6 \%$ in control group. \\
\hline & Setting: Secondary care \\
\hline Interventions & $\begin{array}{l}\text { Interventions: } \\
\text { TAU N=38. } \\
\text { TAU + Psychoeducation } N=38 \text {. Both the groups received psychoeducation plus TAU for } 20 \text { sessions } \\
\text { of } 50 \text { minute each for a period of } 9 \text { months. The psychoeducation in control group did not include } \\
\text { EWS. }\end{array}$ \\
\hline
\end{tabular}

\section{Outcomes}

Time to any recurrence -not reported.

Time to manic episode - not reported

Time to depressive episode - not reported

HAMD,YMRS, GAS scores at 3 months given . Reported number of days in hospital.

Starting date
Contact information
Notes
Poster published in Bipolar Disorders journal and 3 month data was supplied by the Author

\section{DATA AND ANALYSES}

\section{Comparison 1. Treatment as usual (TAU) versus TAU and additional early warning sign recognition}

\begin{tabular}{lllll}
\hline Outcome or subgroup title & No. of studies & $\begin{array}{l}\text { No. of partici- } \\
\text { pants }\end{array}$ & Statistical method & Effect size \\
\hline $\begin{array}{l}1 \text { Time to first recurrence of any } \\
\text { type }\end{array}$ & 6 & 690 & $\begin{array}{l}\text { Hazards ratio (Random, 95\% } \\
\mathrm{Cl})\end{array}$ & $0.57[0.39,0.82]$ \\
\hline $\begin{array}{l}\text { 2 Time to manic/hypomanic } \\
\text { episode }\end{array}$ & 4 & 533 & $\begin{array}{l}\text { Hazards ratio (Random, 95\% } \\
\text { Cl) }\end{array}$ & $0.66[0.40,1.06]$ \\
\hline $\begin{array}{l}\text { 3 Time to depressive episode } \\
\text { 4 Percentage of people hospitalised }\end{array}$ & 4 & 533 & $\begin{array}{l}\text { Hazards ratio (Random, 95\% } \\
\text { Cl) }\end{array}$ & $0.57[0.33,0.99]$ \\
\hline
\end{tabular}




\begin{tabular}{lllll}
\hline Outcome or subgroup title & No. of studies & $\begin{array}{l}\text { No. of partici- } \\
\text { pants }\end{array}$ & Statistical method & Effect size \\
\hline 5 Measure of functioning & 1 & 207 & $\begin{array}{l}\text { Mean Difference (IV, Random, } \\
95 \% \mathrm{Cl})\end{array}$ & 1.20 [0.30, 2.10] \\
\hline $\begin{array}{l}5.1 \text { MRC social perfomance scale at } \\
6 \text { months }\end{array}$ & 1 & 69 & Mean Difference (IV, Random, & $0.43[-0.76,1.62]$ \\
\hline $\begin{array}{l}5.2 \text { MRC social perfomance scale at } \\
12 \text { months }\end{array}$ & 1 & & Mean Difference (IV, Random, & 1.24 [-0.07, 2.55] \\
\hline $\begin{array}{l}5.3 \text { MRC social perfomance scale at } \\
18 \text { months }\end{array}$ & 1 & 69 & $95 \%$ Cl) & $\begin{array}{l}\text { Mean Difference (IV, Random, } \\
95 \% \text { Cl) }\end{array}$ \\
\hline
\end{tabular}

Analysis 1.1. Comparison 1 Treatment as usual (TAU) versus TAU and additional early warning sign recognition, Outcome 1 Time to first recurrence of any type.

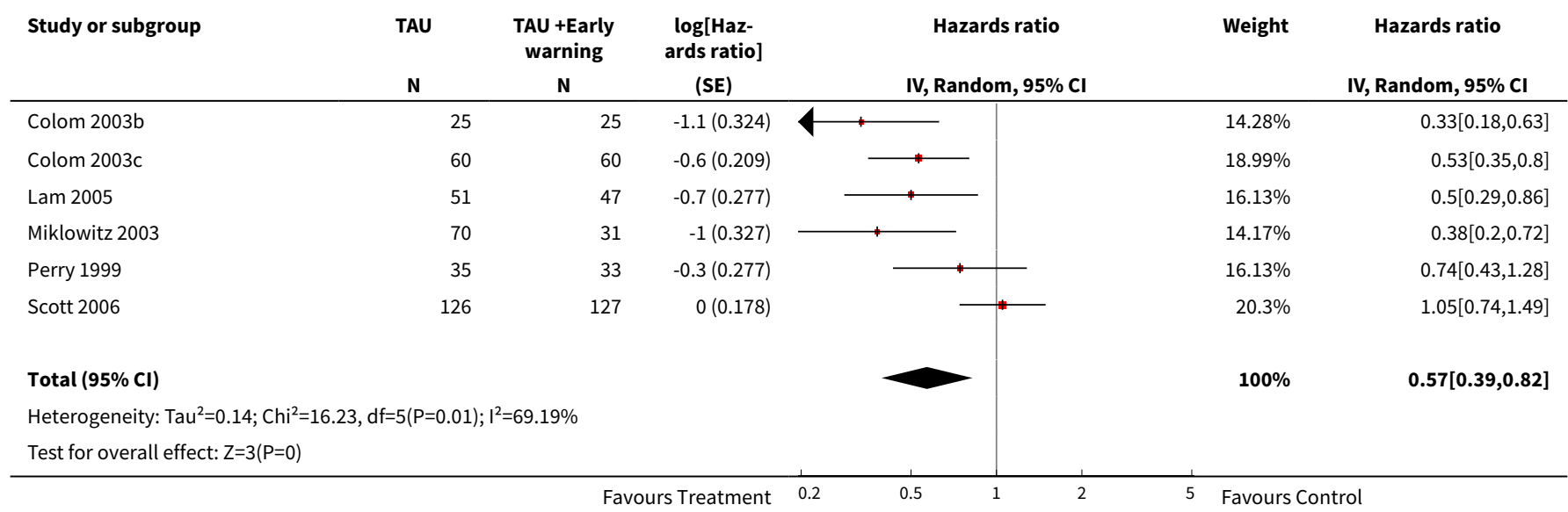

Analysis 1.2. Comparison 1 Treatment as usual (TAU) versus TAU and additional early warning sign recognition, Outcome 2 Time to manic/hypomanic episode.

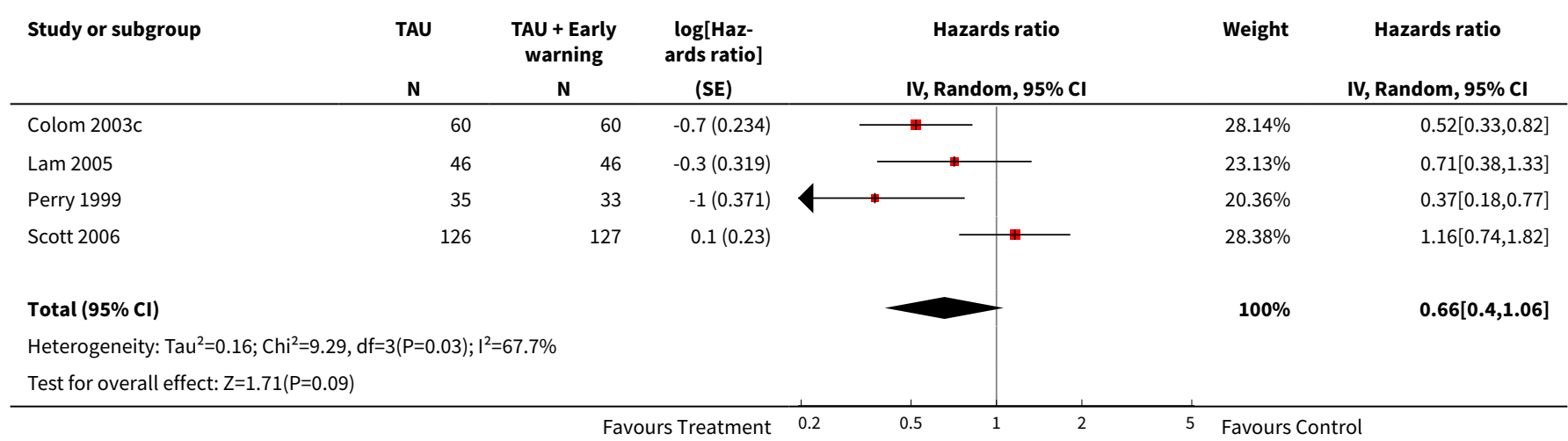


Analysis 1.3. Comparison 1 Treatment as usual (TAU) versus TAU and additional early warning sign recognition, Outcome 3 Time to depressive episode.

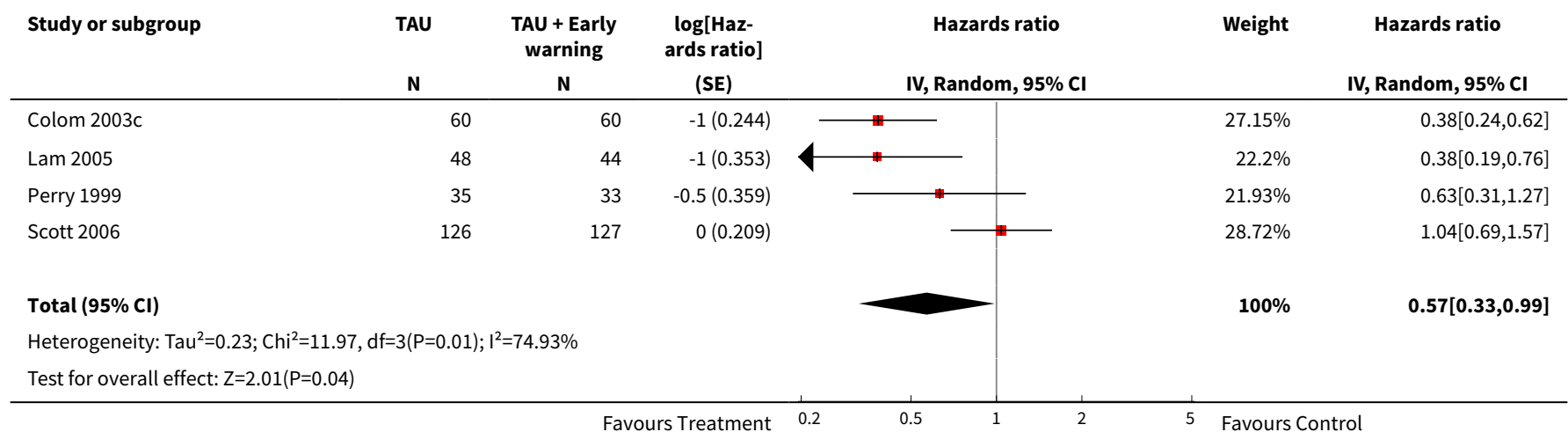

Analysis 1.4. Comparison 1 Treatment as usual (TAU) versus TAU and additional early warning sign recognition, Outcome 4 Percentage of people hospitalised.

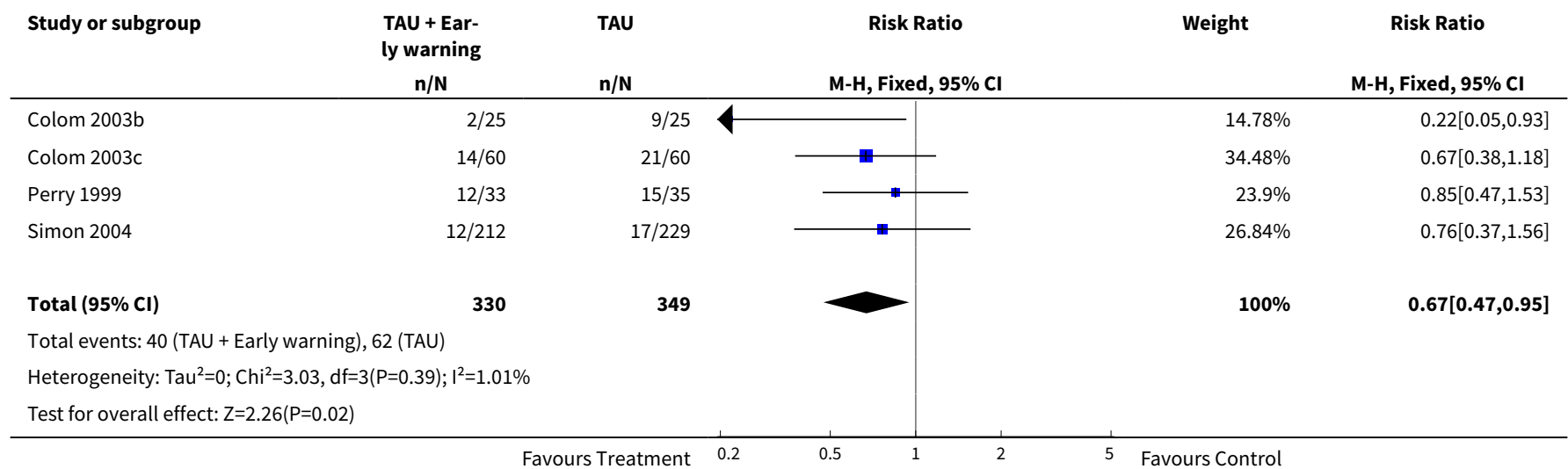

Analysis 1.5. Comparison 1 Treatment as usual (TAU) versus TAU and additional early warning sign recognition, Outcome 5 Measure of functioning.

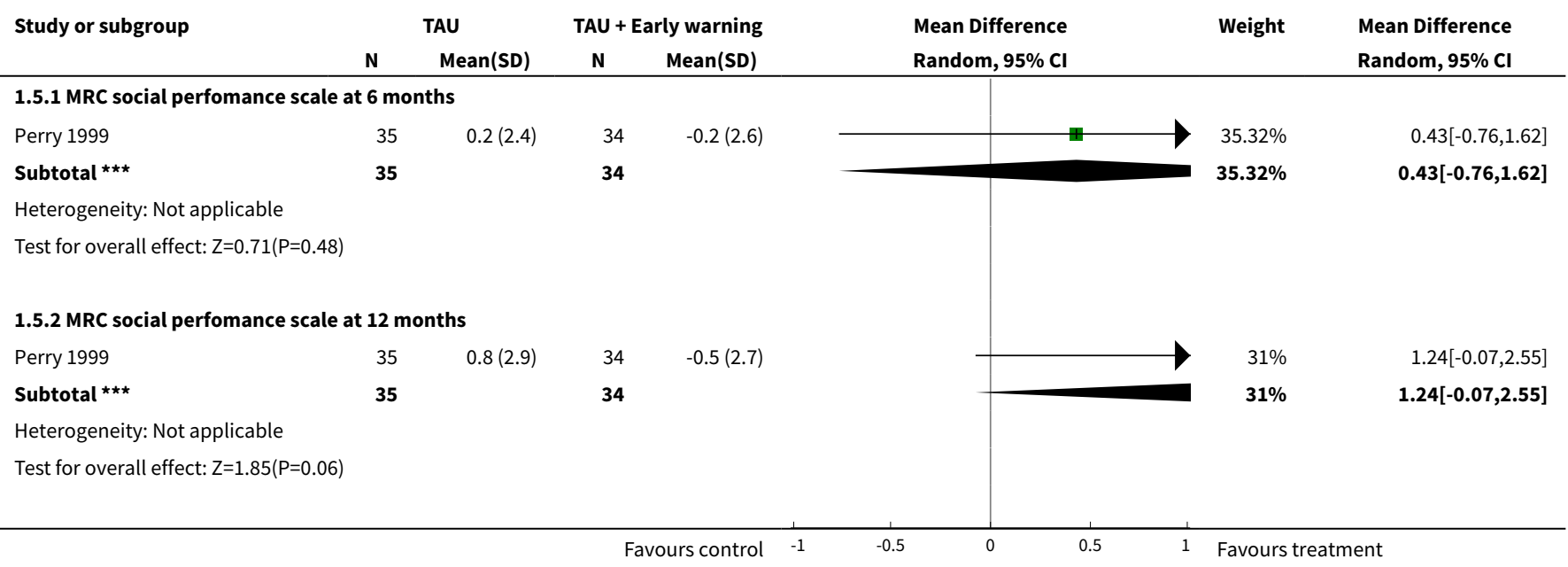




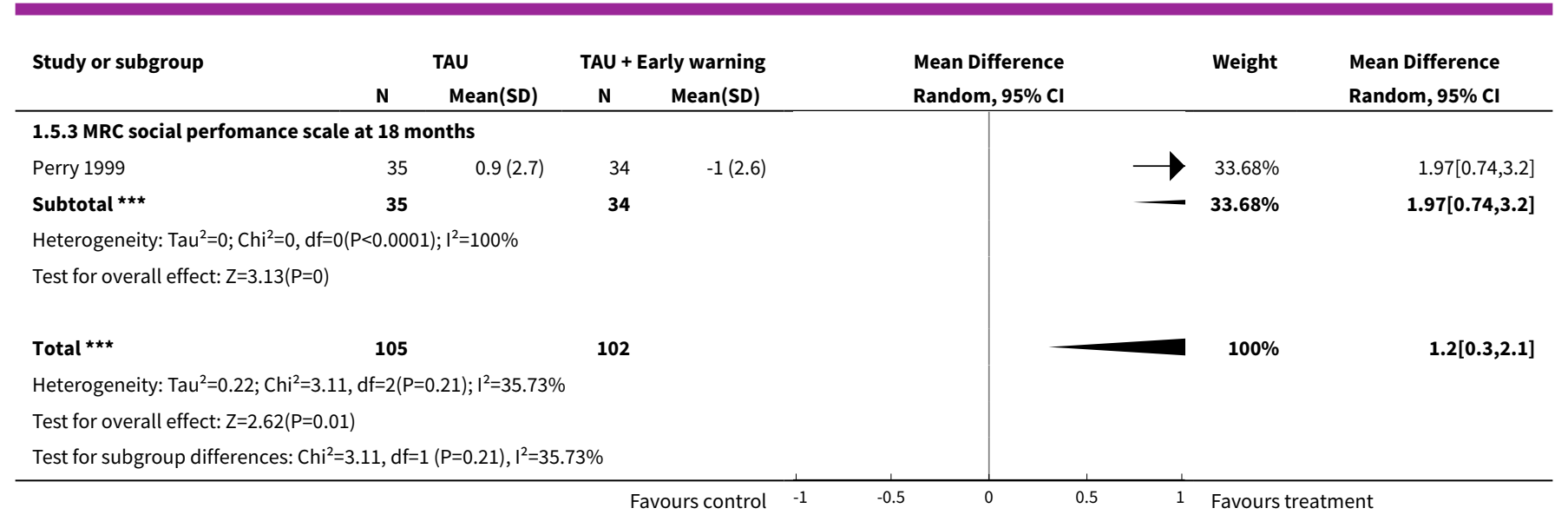

\section{Comparison 2. Heterogeneity}

\begin{tabular}{|c|c|c|c|c|}
\hline Outcome or subgroup title & No. of studies & $\begin{array}{l}\text { No. of partici- } \\
\text { pants }\end{array}$ & Statistical method & Effect size \\
\hline $\begin{array}{l}1 \text { EWS intervention vs psychological con- } \\
\text { trol group for time to first recurrence of any } \\
\text { type }\end{array}$ & 6 & & $\begin{array}{l}\text { Hazards ratio (Random, } \\
95 \% \mathrm{Cl} \text { ) }\end{array}$ & $0.66[0.48,0.91]$ \\
\hline 1.1 EWS intervention & 4 & & $\begin{array}{l}\text { Hazards ratio (Random, } \\
95 \% \mathrm{Cl} \text { ) }\end{array}$ & $0.65[0.41,1.03]$ \\
\hline 1.2 psychological control group & 2 & & $\begin{array}{l}\text { Hazards ratio (Random, } \\
95 \% \mathrm{Cl} \text { ) }\end{array}$ & $0.65[0.39,1.09]$ \\
\hline $\begin{array}{l}2 \text { EWS intervention vs psychological con- } \\
\text { trol group for time to manic/hypomanic } \\
\text { episode }\end{array}$ & 4 & & $\begin{array}{l}\text { Hazards ratio (Random, } \\
95 \% \mathrm{Cl} \text { ) }\end{array}$ & $0.65[0.41,1.03]$ \\
\hline 2.1 EWS intervention & 3 & & $\begin{array}{l}\text { Hazards ratio (Random, } \\
95 \% \mathrm{Cl} \text { ) }\end{array}$ & $0.70[0.39,1.25]$ \\
\hline 2.2 Psychological control group & 1 & & $\begin{array}{l}\text { Hazards ratio (Random, } \\
95 \% \mathrm{Cl} \text { ) }\end{array}$ & $0.52[0.33,0.82]$ \\
\hline $\begin{array}{l}3 \text { EWS intervention vs psychological con- } \\
\text { trol group for time to depressive episode }\end{array}$ & 4 & & $\begin{array}{l}\text { Hazards ratio (Random, } \\
95 \% \mathrm{Cl} \text { ) }\end{array}$ & $0.57[0.33,0.99]$ \\
\hline 3.1 EWS intervention & 3 & & $\begin{array}{l}\text { Hazards ratio (Random, } \\
95 \% \mathrm{Cl} \text { ) }\end{array}$ & $0.66[0.36,1.22]$ \\
\hline 3.2 psychological control group & 1 & & $\begin{array}{l}\text { Hazards ratio (Random, } \\
95 \% \mathrm{Cl} \text { ) }\end{array}$ & $0.38[0.24,0.62]$ \\
\hline $\begin{array}{l}4 \text { Time to first recurrence of any type for } \\
\text { TAU Vs enhanced TAU }\end{array}$ & 4 & & $\begin{array}{l}\text { Hazards ratio (Random, } \\
95 \% \mathrm{Cl} \text { ) }\end{array}$ & $0.65[0.41,1.03]$ \\
\hline 4.1 Studies including only TAU & 3 & & $\begin{array}{l}\text { Hazards ratio (Random, } \\
95 \% \mathrm{Cl} \text { ) }\end{array}$ & $0.76[0.49,1.18]$ \\
\hline
\end{tabular}




\begin{tabular}{|c|c|c|c|c|}
\hline Outcome or subgroup title & No. of studies & $\begin{array}{l}\text { No. of partici- } \\
\text { pants }\end{array}$ & Statistical method & Effect size \\
\hline 4.2 Studies including enhanced TAU & 1 & & $\begin{array}{l}\text { Hazards ratio (Random, } \\
95 \% \mathrm{Cl} \text { ) }\end{array}$ & $0.38[0.20,0.72]$ \\
\hline $\begin{array}{l}5 \text { Time to first recurrence of any type for In- } \\
\text { tervention delivered in groups vs individu- } \\
\text { ally }\end{array}$ & 6 & & $\begin{array}{l}\text { Hazards ratio (Random, } \\
95 \% \mathrm{Cl} \text { ) }\end{array}$ & $0.66[0.48,0.91]$ \\
\hline 5.1 intervention delivered individually & 3 & & $\begin{array}{l}\text { Hazards ratio (Random, } \\
95 \% \mathrm{Cl} \text { ) }\end{array}$ & $0.76[0.49,1.18]$ \\
\hline 5.2 intervention delivered in groups & 3 & & $\begin{array}{l}\text { Hazards ratio (Random, } \\
95 \% \mathrm{Cl} \text { ) }\end{array}$ & $0.56[0.37,0.87]$ \\
\hline $\begin{array}{l}6 \text { Inclusion one month after episode vs re- } \\
\text { cruitment during episode }\end{array}$ & 6 & & $\begin{array}{l}\text { Hazards ratio (Random, } \\
95 \% \mathrm{Cl} \text { ) }\end{array}$ & $0.66[0.48,0.91]$ \\
\hline $\begin{array}{l}\text { 6.1 Time to first recurrence of any type for } \\
\text { studies recruiting one month after episode }\end{array}$ & 4 & & $\begin{array}{l}\text { Hazards ratio (Random, } \\
95 \% \mathrm{Cl} \text { ) }\end{array}$ & $0.62[0.48,0.80]$ \\
\hline $\begin{array}{l}6.2 \text { Time to first recurrence of any type for } \\
\text { studies recruiting people during episode }\end{array}$ & 2 & & $\begin{array}{l}\text { Hazards ratio (Random, } \\
95 \% \mathrm{Cl} \text { ) }\end{array}$ & $0.66[0.24,1.77]$ \\
\hline $\begin{array}{l}7 \text { Time to first recurrence of any type for } \\
\text { simple VS complex intervention for EWS }\end{array}$ & 6 & & $\begin{array}{l}\text { Hazard ratio (Random, } \\
95 \% \mathrm{Cl} \text { ) }\end{array}$ & $0.57[0.39,0.82]$ \\
\hline 7.1 Simple intervention for EWS & 1 & & $\begin{array}{l}\text { Hazard ratio (Random, } \\
95 \% \mathrm{Cl} \text { ) }\end{array}$ & $0.74[0.43,1.28]$ \\
\hline 7.2 Complex intervention for EWS & 5 & & $\begin{array}{l}\text { Hazard ratio (Random, } \\
95 \% \mathrm{Cl} \text { ) }\end{array}$ & $0.54[0.35,0.83]$ \\
\hline $\begin{array}{l}8 \text { Time to manic/hypomanic episode for } \\
\text { simple Vs complex intervention for EWS }\end{array}$ & 4 & & $\begin{array}{l}\text { Hazards ratio (Random, } \\
95 \% \mathrm{Cl} \text { ) }\end{array}$ & $0.66[0.40,1.06]$ \\
\hline 8.1 Simple intervention for EWS & 1 & & $\begin{array}{l}\text { Hazards ratio (Random, } \\
95 \% \mathrm{Cl} \text { ) }\end{array}$ & $0.37[0.18,0.77]$ \\
\hline 8.2 Complex intervention for EWS & 3 & & $\begin{array}{l}\text { Hazards ratio (Random, } \\
95 \% \mathrm{Cl} \text { ) }\end{array}$ & $0.76[0.46,1.26]$ \\
\hline $\begin{array}{l}9 \text { Time to depressive episode for simple Vs } \\
\text { complex intervention for EWS }\end{array}$ & 4 & & $\begin{array}{l}\text { Hazards ratio (Random, } \\
95 \% \mathrm{Cl} \text { ) }\end{array}$ & $0.57[0.33,0.99]$ \\
\hline 9.1 Simple intervention for EWS & 1 & & $\begin{array}{l}\text { Hazards ratio (Random, } \\
95 \% \mathrm{Cl} \text { ) }\end{array}$ & $0.63[0.31,1.27]$ \\
\hline 9.2 Complex intervention for EWS & 3 & & $\begin{array}{l}\text { Hazards ratio (Random, } \\
95 \% \mathrm{Cl} \text { ) }\end{array}$ & $0.55[0.26,1.13]$ \\
\hline $\begin{array}{l}10 \text { Time to first recurrence in studies where } \\
\text { EWS as primary focus Vs EWS as secondary } \\
\text { focus }\end{array}$ & 6 & & $\begin{array}{l}\text { Hazards ratio (Fixed, 95\% } \\
\mathrm{Cl} \text { ) }\end{array}$ & $0.70[0.57,0.85]$ \\
\hline $\begin{array}{l}10.1 \text { Studies where EWS is the primary fo- } \\
\text { cus }\end{array}$ & 5 & & $\begin{array}{l}\text { Hazards ratio (Fixed, 95\% } \\
\mathrm{Cl} \text { ) }\end{array}$ & $0.58[0.45,0.73]$ \\
\hline
\end{tabular}




\begin{tabular}{llll}
\hline $\begin{array}{l}\text { Outcome or subgroup title } \\
\text { No. of studies }\end{array}$ & $\begin{array}{l}\text { No. of partici- } \\
\text { pants }\end{array}$ & Statistical method & Effect size \\
\hline $\begin{array}{l}10.2 \text { Studies where EWS is the secondary } \\
\text { focus }\end{array}$ & 1 & $\begin{array}{l}\text { Hazards ratio (Fixed, 95\% } \\
\text { Cl) }\end{array}$ & $1.05[0.74,1.49]$ \\
\hline $\begin{array}{l}11 \text { Time to manic episode in studies where } \\
\text { EWS as primary focus Vs EWS as secondary } \\
\text { focus }\end{array}$ & 4 & $\begin{array}{l}\text { Hazards ratio (Fixed, 95\% } \\
\text { Cl) }\end{array}$ & $0.73[0.58,0.93]$ \\
\hline $\begin{array}{l}11.1 \text { studies where EWS is the primary fo- } \\
\text { cus }\end{array}$ & 3 & $\begin{array}{l}\text { Hazards ratio (Fixed, 95\% } \\
\text { Cl) }\end{array}$ & $0.53[0.38,0.74]$ \\
\hline $\begin{array}{l}11.2 \text { Studies where EWS is the secondary } \\
\text { focus }\end{array}$ & 1 & $\begin{array}{l}\text { Hazards ratio (Fixed, 95\% } \\
\text { Cl) }\end{array}$ & $1.05[0.74,1.49]$ \\
\hline $\begin{array}{l}12 \text { Time to depressive episode in studies } \\
\text { where EWS as primary focus Vs EWS as sec- } \\
\text { ondary focus }\end{array}$ & 4 & $\begin{array}{l}\text { Hazards ratio (Fixed, 95\% } \\
\text { Cl) }\end{array}$ & $0.62[0.48,0.81]$ \\
\hline $\begin{array}{l}12.1 \text { Studies where EWS is the primary fo- } \\
\text { cus }\end{array}$ & 3 & $\begin{array}{l}\text { Hazards ratio (Fixed, 95\% } \\
\text { Cl) }\end{array}$ & $0.43[0.31,0.61]$ \\
\hline $\begin{array}{l}12.2 \text { Studies where EWS is the secondary } \\
\text { focus }\end{array}$ & 1 & $\begin{array}{l}\text { Hazards ratio (Fixed, 95\% } \\
\text { Cl) }\end{array}$ & $1.04[0.69,1.57]$ \\
\hline
\end{tabular}

\section{Analysis 2.1. Comparison 2 Heterogeneity, Outcome 1 EWS intervention vs psychological control group for time to first recurrence of any type.}

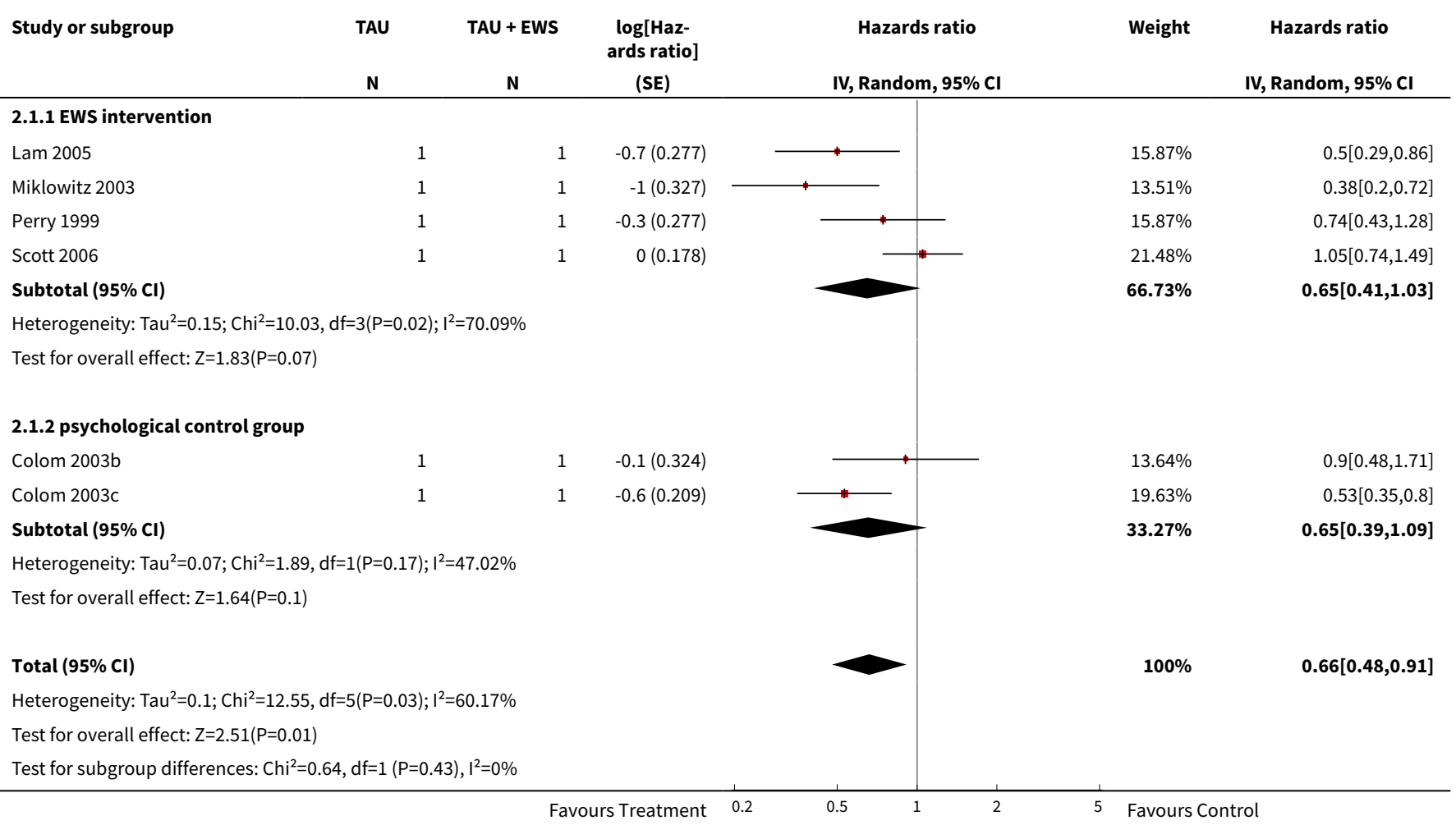


Analysis 2.2. Comparison 2 Heterogeneity, Outcome 2 EWS intervention vs psychological control group for time to manic/hypomanic episode.

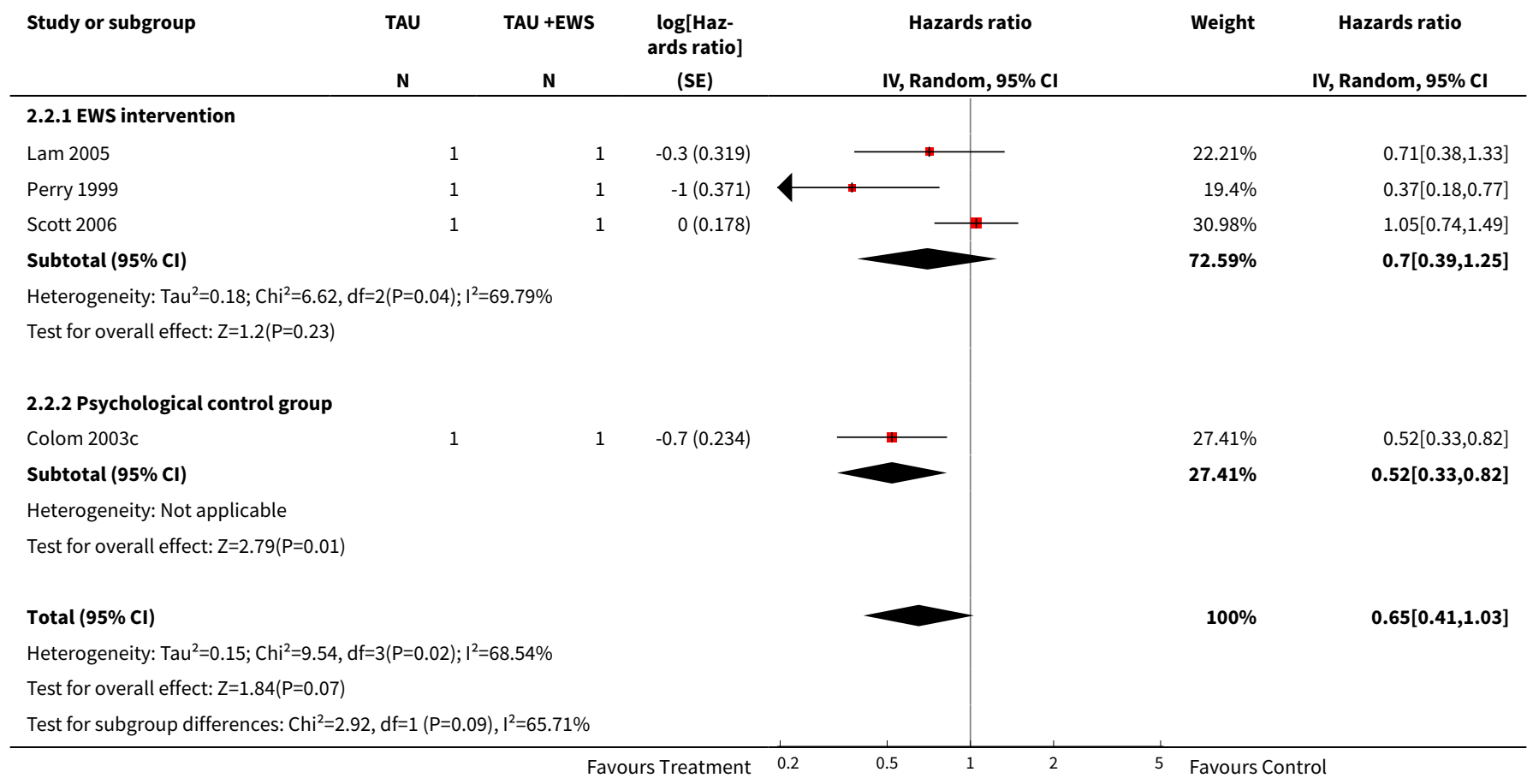

Analysis 2.3. Comparison 2 Heterogeneity, Outcome 3 EWS intervention vs psychological control group for time to depressive episode.

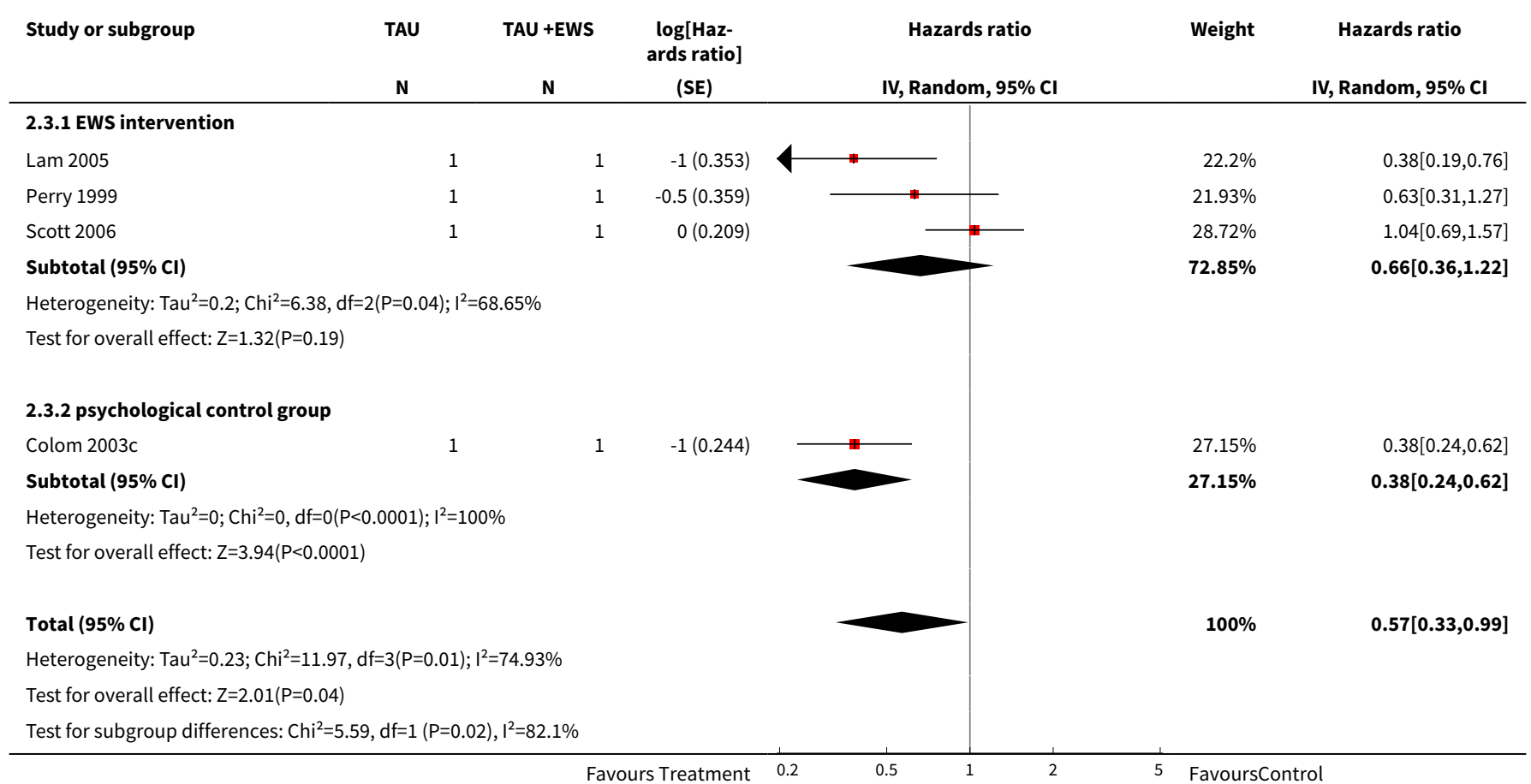


Analysis 2.4. Comparison 2 Heterogeneity, Outcome 4 Time to first recurrence of any type for TAU Vs enhanced TAU.

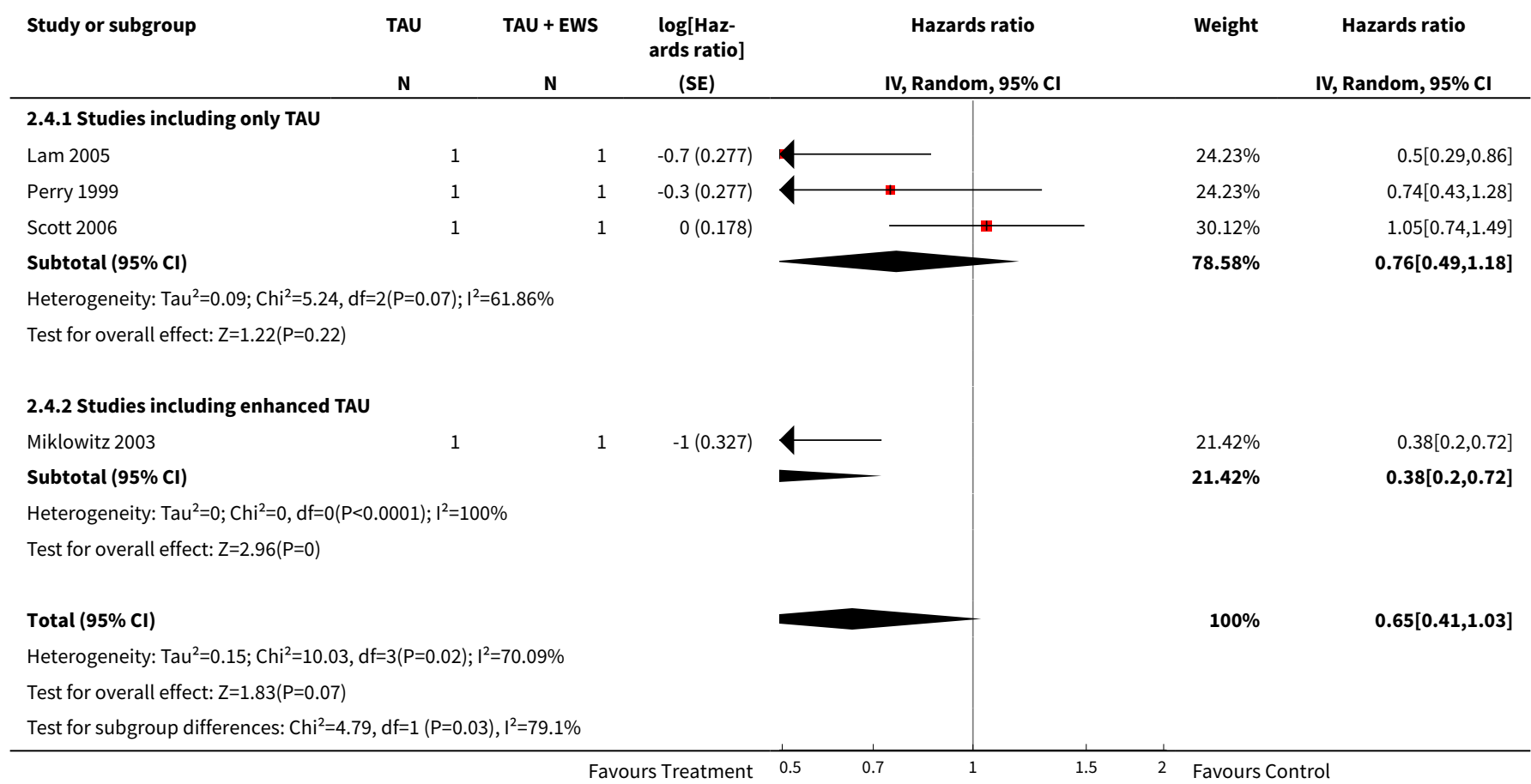

Analysis 2.5. Comparison 2 Heterogeneity, Outcome 5 Time to first recurrence of any type for Intervention delivered in groups vs individually.

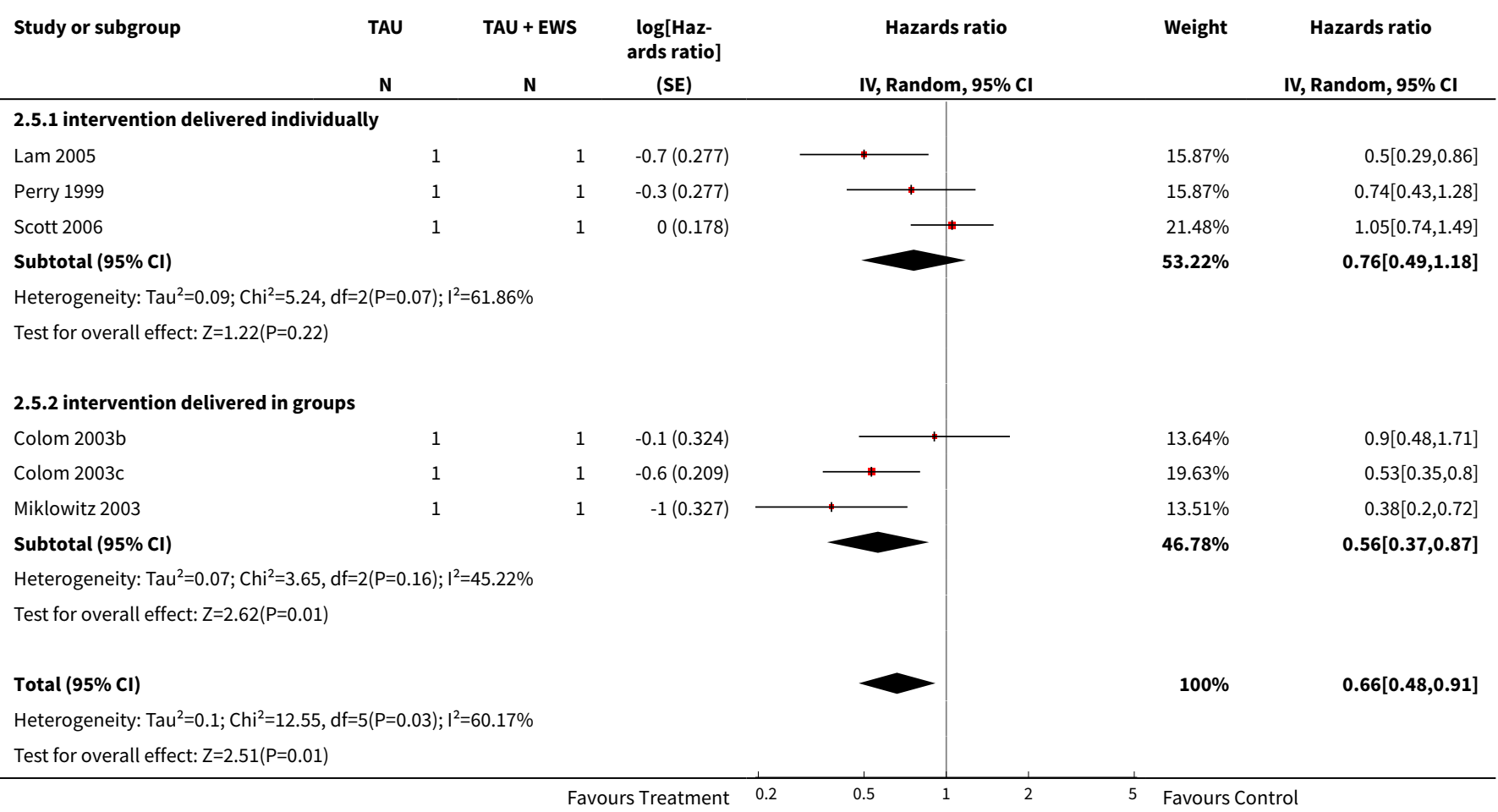




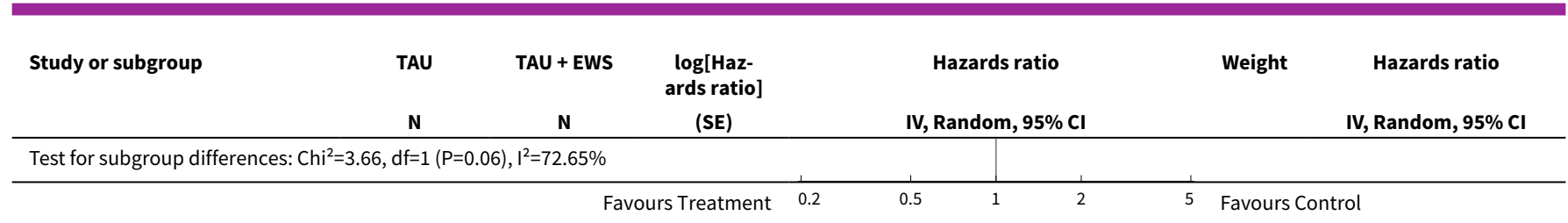

\section{Analysis 2.6. Comparison 2 Heterogeneity, Outcome 6 Inclusion one month after episode vs recruitment during episode.}

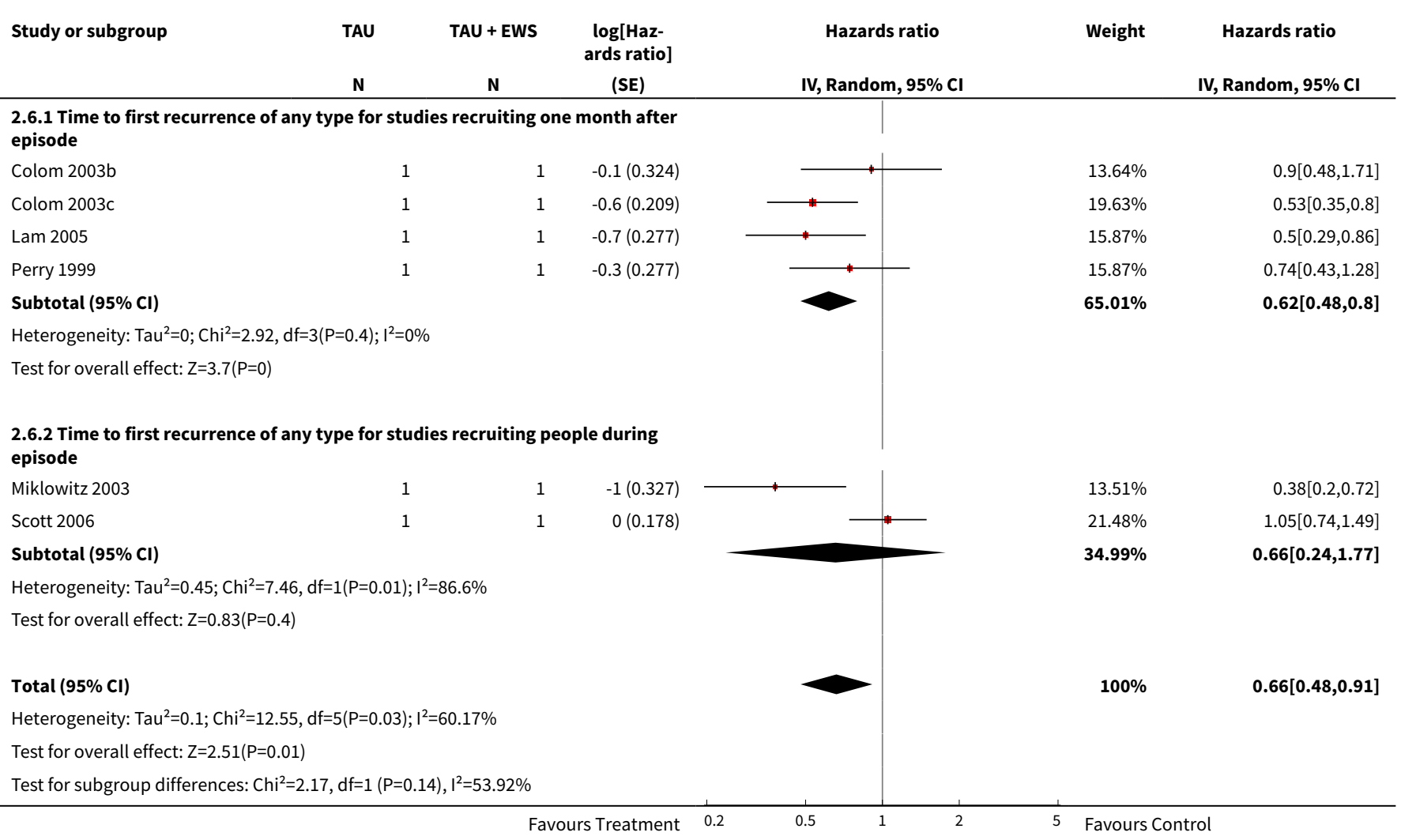

Analysis 2.7. Comparison 2 Heterogeneity, Outcome 7 Time to first recurrence of any type for simple VS complex intervention for EWS.

\begin{tabular}{|c|c|c|c|c|c|c|}
\hline \multirow[t]{2}{*}{ Study or subgroup } & \multirow{2}{*}{$\begin{array}{l}\text { TAU } \\
\mathbf{N} \\
\end{array}$} & \multirow{2}{*}{$\begin{array}{c}\text { TAU + EWS } \\
\mathbf{N} \\
\end{array}$} & \multirow{2}{*}{$\begin{array}{l}\log [\mathrm{Haz}- \\
\text { ard ratio }] \\
(\mathrm{SE})\end{array}$} & \multirow{2}{*}{$\begin{array}{c}\text { Hazard ratio } \\
\text { IV, Random, } 95 \% \mathrm{Cl}\end{array}$} & \multirow[t]{2}{*}{ Weight } & \multirow{2}{*}{$\begin{array}{c}\text { Hazard ratio } \\
\text { IV, Random, 95\% CI }\end{array}$} \\
\hline & & & & & & \\
\hline \multicolumn{7}{|c|}{ 2.7.1 Simple intervention for EWS } \\
\hline Perry 1999 & 1 & 1 & $-0.3(0.277)$ & \begin{tabular}{l|l}
$*$ & \\
$*$ &
\end{tabular} & $16.13 \%$ & $0.74[0.43,1.28]$ \\
\hline Subtotal $(95 \% \mathrm{Cl})$ & & & & & $16.13 \%$ & $0.74[0.43,1.28]$ \\
\hline \multicolumn{7}{|c|}{ Heterogeneity: Not applicable } \\
\hline \multicolumn{7}{|c|}{ 2.7.2 Complex intervention for EWS } \\
\hline Colom 2003b & 1 & 1 & $-1.1(0.324)$ & & $14.28 \%$ & $0.33[0.18,0.63]$ \\
\hline
\end{tabular}




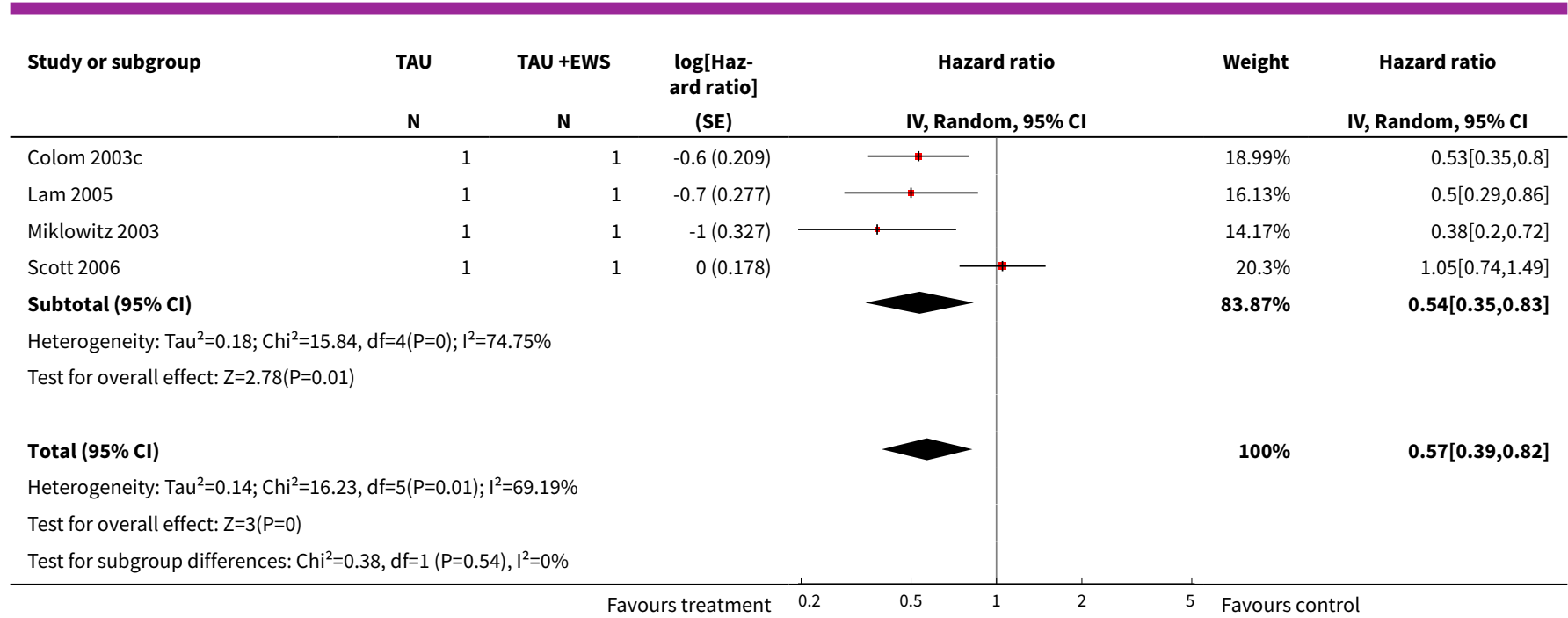

\section{Analysis 2.8. Comparison 2 Heterogeneity, Outcome 8 Time to manic/ hypomanic episode for simple Vs complex intervention for EWS.}

\begin{tabular}{|c|c|c|c|c|c|c|}
\hline \multirow[t]{2}{*}{ Study or subgroup } & \multirow{2}{*}{$\begin{array}{l}\text { TAU } \\
\mathbf{N} \\
\end{array}$} & TAU + EWS & \multirow{2}{*}{$\begin{array}{l}\log [\mathrm{Haz}- \\
\text { ards ratio] } \\
(\mathrm{SE})\end{array}$} & \multirow{2}{*}{$\begin{array}{c}\text { Hazards ratio } \\
\text { IV, Random, } 95 \% \mathrm{CI}\end{array}$} & \multirow[t]{2}{*}{ Weight } & \multirow{2}{*}{$\begin{array}{c}\text { Hazards ratio } \\
\text { IV, Random, } 95 \% \text { CI }\end{array}$} \\
\hline & & $\mathbf{N}$ & & & & \\
\hline \multicolumn{7}{|c|}{ 2.8.1 Simple intervention for EWS } \\
\hline Perry 1999 & 1 & 1 & $-1(0.371)$ & & $20.36 \%$ & $0.37[0.18,0.77]$ \\
\hline Subtotal $(95 \% \mathrm{Cl})$ & & & & & $20.36 \%$ & $0.37[0.18,0.77]$ \\
\hline \multicolumn{7}{|c|}{ Heterogeneity: Not applicable } \\
\hline \multicolumn{7}{|c|}{ 2.8.2 Complex intervention for EWS } \\
\hline Colom 2003c & 1 & 1 & $-0.7(0.234)$ & & $28.14 \%$ & $0.52[0.33,0.82]$ \\
\hline Lam 2005 & 1 & 1 & $-0.3(0.319)$ & \begin{tabular}{l|l}
$*$ & \\
- & -1
\end{tabular} & $23.13 \%$ & $0.71[0.38,1.33]$ \\
\hline Scott 2006 & 1 & 1 & $0.1(0.23)$ & 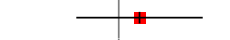 & $28.38 \%$ & $1.16[0.74,1.82]$ \\
\hline Subtotal $(95 \% \mathrm{Cl})$ & & & & & $79.64 \%$ & $0.76[0.46,1.26]$ \\
\hline \multicolumn{7}{|c|}{ Heterogeneity: $\mathrm{Tau}^{2}=0.13 ; \mathrm{Chi}^{2}=6.03, \mathrm{df}=2(\mathrm{P}=0.05) ; \mathrm{I}^{2}=66.84 \%$} \\
\hline \multicolumn{7}{|c|}{ Test for overall effect: $Z=1.07(P=0.29)$} \\
\hline Total $(95 \% \mathrm{Cl})$ & & & & & $100 \%$ & $0.66[0.4,1.06]$ \\
\hline \multicolumn{7}{|c|}{ Heterogeneity: $\mathrm{Tau}^{2}=0.16 ; \mathrm{Chi}^{2}=9.29, \mathrm{df}=3(\mathrm{P}=0.03) ; \mathrm{I}^{2}=67.7 \%$} \\
\hline \multicolumn{7}{|c|}{ Test for overall effect: $Z=1.71(P=0.09)$} \\
\hline Test for subgroup dif & $d f=1(P=0$. & $I^{2}=69.28 \%$ & & & & \\
\hline
\end{tabular}


Analysis 2.9. Comparison 2 Heterogeneity, Outcome 9 Time to depressive episode for simple Vs complex intervention for EWS.

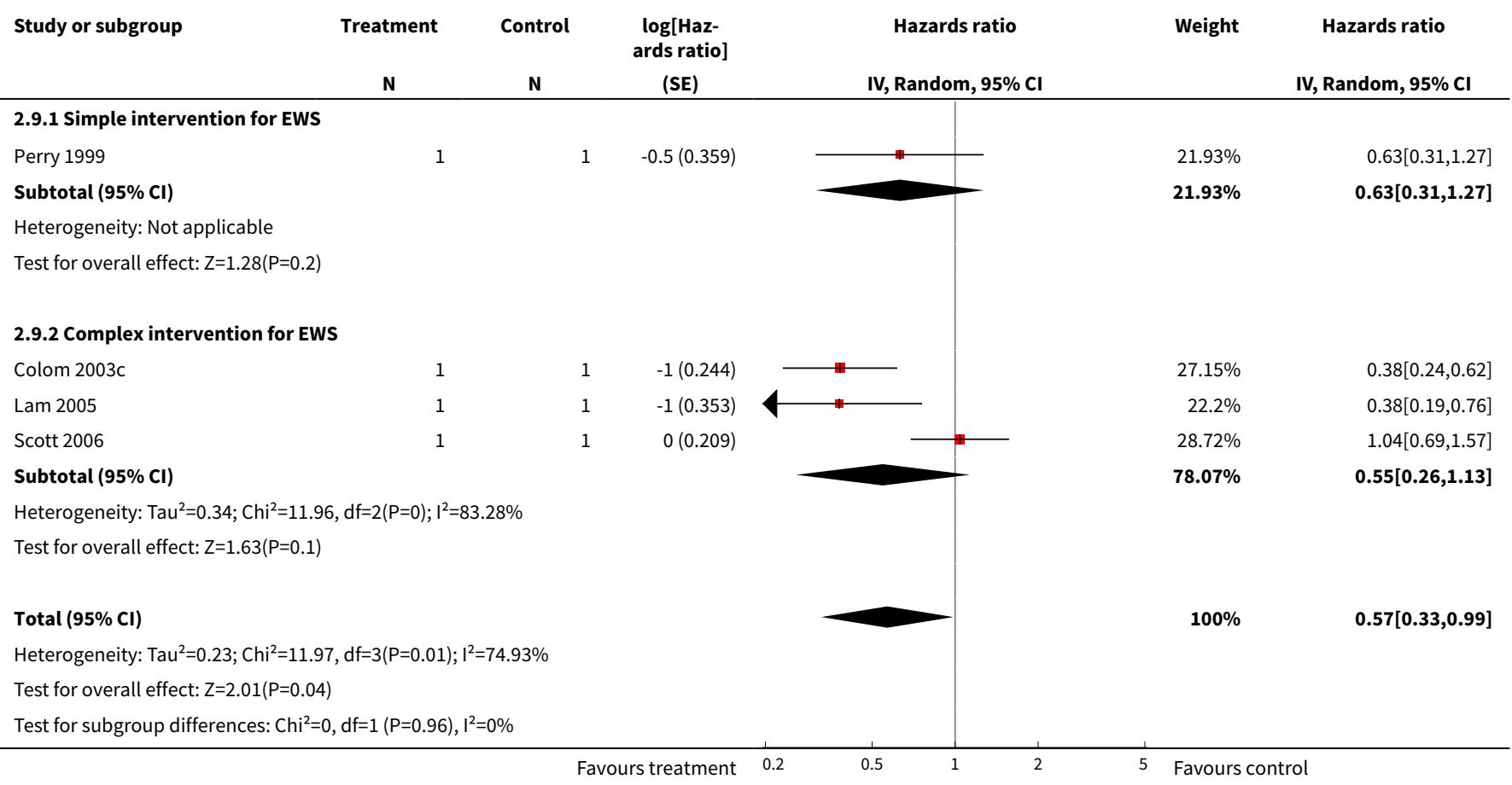

Analysis 2.10. Comparison 2 Heterogeneity, Outcome 10 Time to first recurrence in studies where EWS as primary focus Vs EWS as secondary focus.

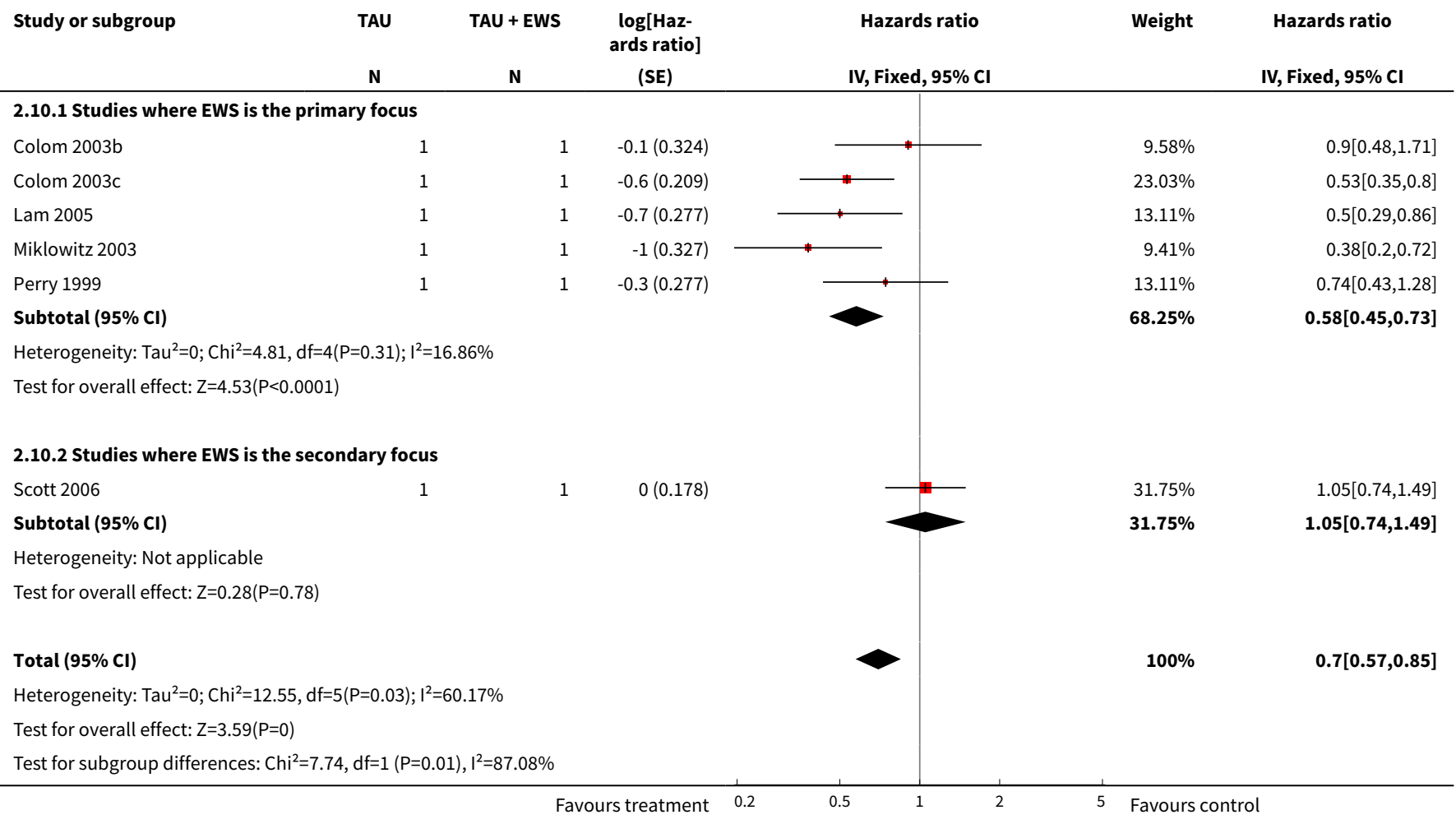


Analysis 2.11. Comparison 2 Heterogeneity, Outcome 11 Time to manic episode in studies where EWS as primary focus Vs EWS as secondary focus.

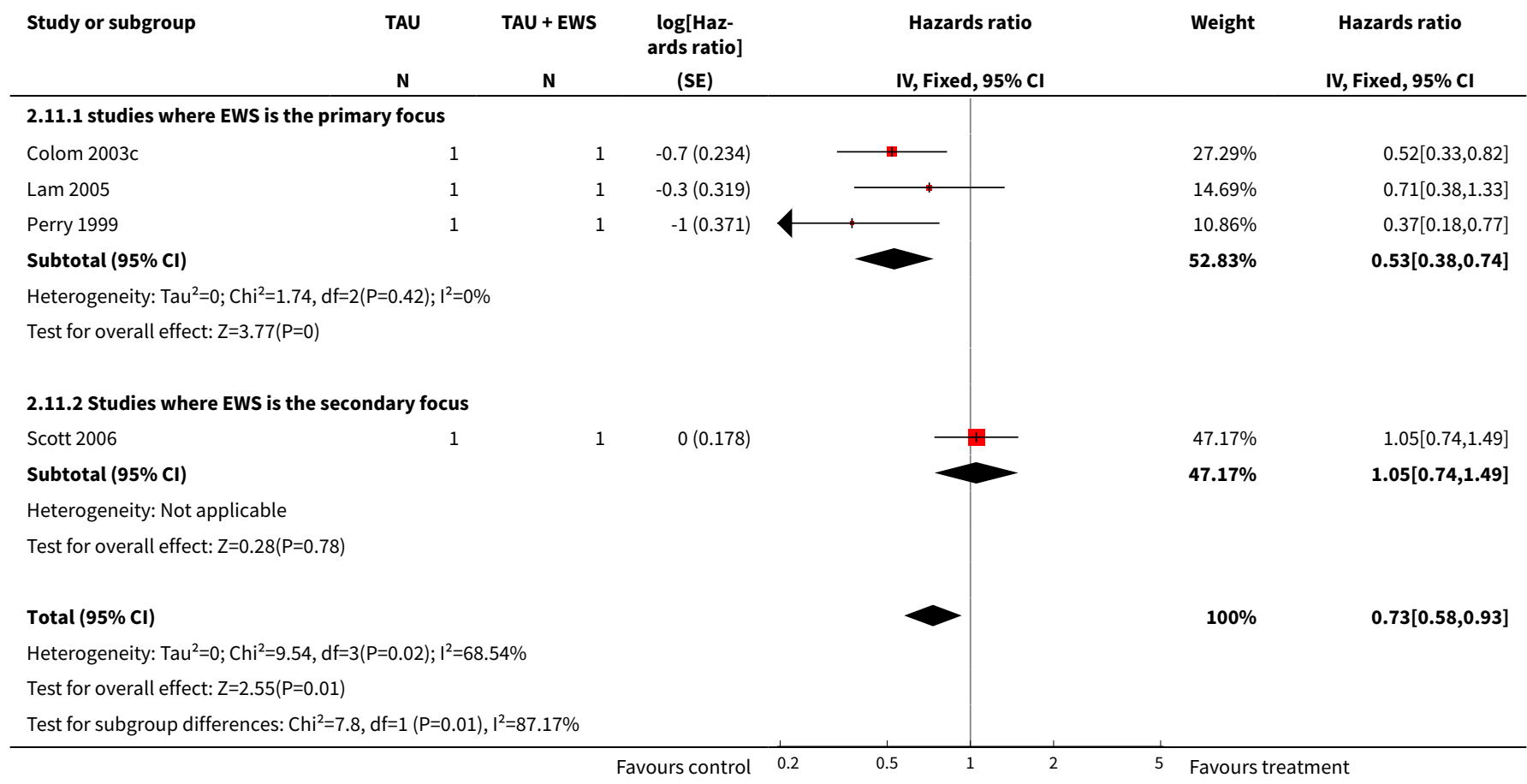

Analysis 2.12. Comparison 2 Heterogeneity, Outcome 12 Time to depressive episode in studies where EWS as primary focus Vs EWS as secondary focus.

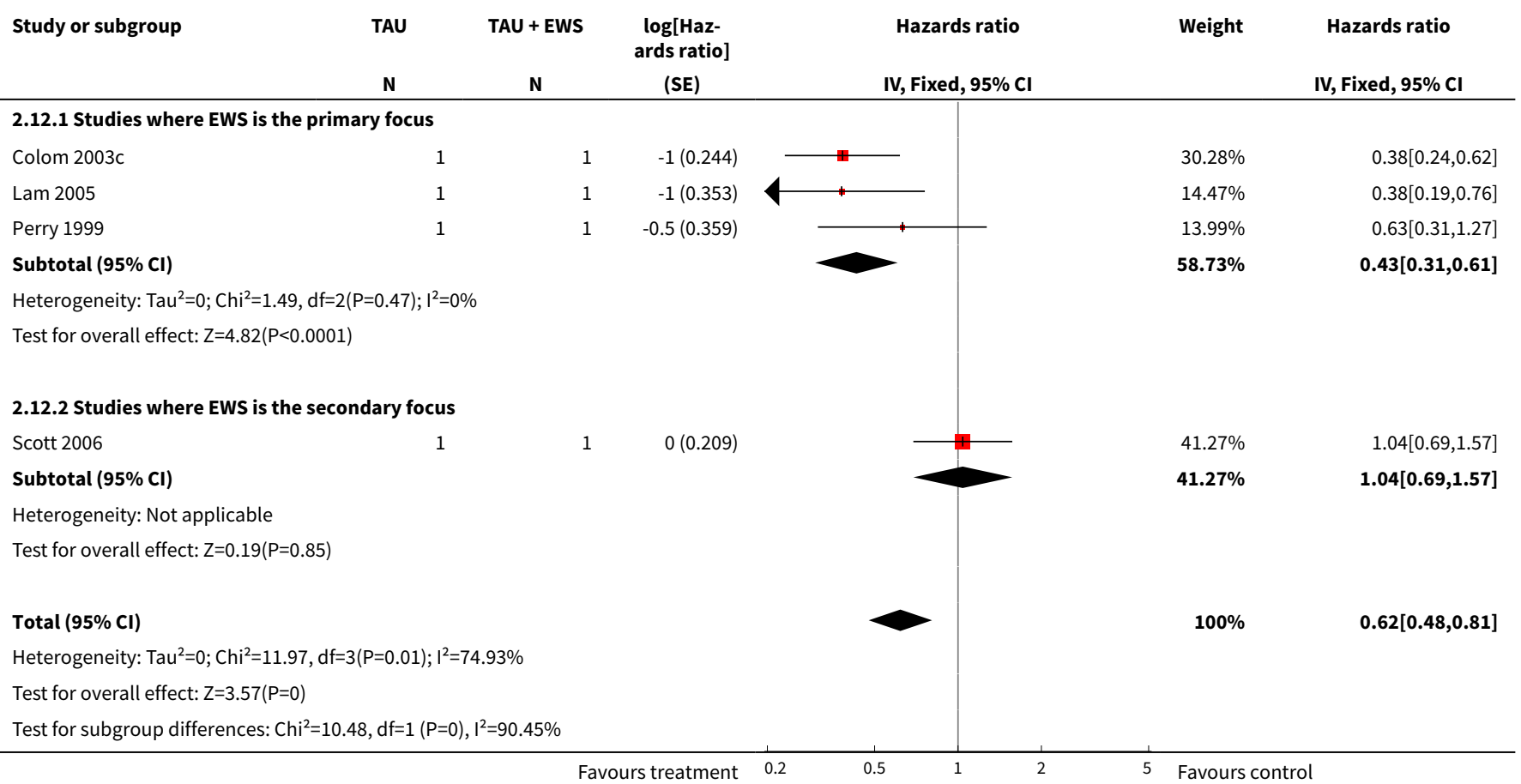


ADDITIONAL TABLES

Table 1. Methodological quality of included studies

\begin{tabular}{|c|c|c|c|c|}
\hline Study & Allocation & Randomisation & Blinding & ITT \\
\hline Colom 2003 & $A$ & $\begin{array}{l}\text { by computerised number } \\
\text { generator }\end{array}$ & $\begin{array}{l}\text { Only outcome } \\
\text { asessor blinded }\end{array}$ & ITT principle used \\
\hline Colom 2003 (a) & A & $\begin{array}{l}\text { by computerised number } \\
\text { generator }\end{array}$ & $\begin{array}{l}\text { Only outcome } \\
\text { asessor blinded }\end{array}$ & ITT principle used \\
\hline Lam 2005 & $A$ & $\begin{array}{l}\text { computer generated allo- } \\
\text { cation sequence }\end{array}$ & $\begin{array}{l}\text { Only outcome } \\
\text { asessor blinded }\end{array}$ & $\begin{array}{l}\text { reports ITT principle used, but data } \\
\text { missing for primary outcome and not re- } \\
\text { ported reasons for it. }\end{array}$ \\
\hline Lam 2000 & B & $\begin{array}{l}\text { randomisation procedure } \\
\text { not described }\end{array}$ & $\begin{array}{l}\text { Only outcome } \\
\text { asessor blinded }\end{array}$ & $\begin{array}{l}\text { Reports ITT principle used. Data on two } \\
\text { patients who dropped out not reported. }\end{array}$ \\
\hline Meyer 2003 & B & $\begin{array}{l}\text { randomisation not de- } \\
\text { scribed. }\end{array}$ & not described & ongoing study \\
\hline Miklowitz 2003 & B & $\begin{array}{l}\text { randomisation by random } \\
\text { number table. } 2: 1 \text { ran- } \\
\text { domisation used. }\end{array}$ & $\begin{array}{l}\text { Only outcome } \\
\text { asessor blinded }\end{array}$ & $\begin{array}{l}\text { accounted for all patients but does not } \\
\text { state whether ITT principle was used. }\end{array}$ \\
\hline Perry 1999 & A & $\begin{array}{l}\text { randomly allocated using } \\
\text { principles of minimisation }\end{array}$ & $\begin{array}{l}\text { Only outcome } \\
\text { asessor blinded }\end{array}$ & $\begin{array}{l}\text { ITT principle used. Data on one patient } \\
\text { missing as patient died due to physical } \\
\text { cause }\end{array}$ \\
\hline Scott 2005 & A & $\begin{array}{l}\text { independent trialists and } \\
\text { biostatistics office allocat- } \\
\text { ed patients to two treat- } \\
\text { ment groups using min- } \\
\text { imisation algorithm }\end{array}$ & $\begin{array}{l}\text { Only outcome } \\
\text { asessor blinded }\end{array}$ & $\begin{array}{l}\text { ITT principle used. Results on four peo- } \\
\text { ple missing and these were included in } \\
\text { final analysis. }\end{array}$ \\
\hline Simon 2004 & A & $\begin{array}{l}\text { using a concealed table } \\
\text { of computer generated } \\
\text { random numberswith no } \\
\text { blocking or staratification }\end{array}$ & $\begin{array}{l}\text { Only outcome } \\
\text { asessor blinded }\end{array}$ & $\begin{array}{l}\text { ITT principle used. In treatment group } \\
199 / 212 \text { were included for symptom } \\
\text { analysis and all included for utilisation } \\
\text { analysis. in control group } 215 / 229 \text { were } \\
\text { included in symptom analysis and all } \\
\text { were included in utilization analysis. }\end{array}$ \\
\hline Vangent 1991 & B & not described & $\begin{array}{l}\text { no blinding, un- } \\
\text { clear if outcome } \\
\text { asessor was blind- } \\
\text { ed }\end{array}$ & $\begin{array}{l}\text { All participants accounted for but does } \\
\text { not state whether ITT principle was } \\
\text { used. }\end{array}$ \\
\hline
\end{tabular}

Table 2. Comparison 01: TAU vS TAU+EWS

\begin{tabular}{llll}
\hline Outcome Title & No of studies & $\begin{array}{l}\text { No of partici- } \\
\text { pants }\end{array}$ & Statistical method \\
\hline
\end{tabular}


Table 2. Comparison 01: TAU vs TAU+EWS (Continued)

\begin{tabular}{llclll} 
Time to any relapse & six & 690 & Hazards ratio random effect $95 \% \mathrm{Cl}$ & $0.57(0.39,0.82)$ \\
\hline $\begin{array}{l}\text { Time to hypomanic /manic } \\
\text { relapse }\end{array}$ & four & 533 & Hazards ratio random effect $95 \% \mathrm{Cl}$ & $0.66(0.40,1.06)$ \\
\hline $\begin{array}{l}\text { Time to depressive relapse } \\
\text { four }\end{array}$ & 533 & Hazards ratio random effect $95 \% \mathrm{Cl}$ & $0.57(0.33,0.99)$ \\
\hline $\begin{array}{l}\text { Percentage of people hospi- } \\
\text { talised }\end{array}$ & four & 679 & Hazards ratio fixed effect $95 \% \mathrm{Cl}$ & $1.49(1.05,2.11)$ \\
\hline
\end{tabular}




\begin{tabular}{|c|c|c|c|c|c|c|c|}
\hline Study & $\begin{array}{l}\text { score at } \\
\text { (months) }\end{array}$ & No in C group & No in $\mathrm{T}$ group & Control group score & $\begin{array}{l}\text { Treatment group } \\
\text { scor }\end{array}$ & $\begin{array}{l}\text { Statistical } \\
\text { method }\end{array}$ & Effect size \\
\hline Lam 2000 & six & 11 & 12 & 7.60 ( 8.92$)$ & $4.83(6.10)$ & WMD 95\% Cl & $2.77(-3.53,9.07)$ \\
\hline Lam 2000 & Twelve & 11 & 12 & $11.56(13.88)$ & $6.18(8.44)$ & WMD $95 \% \mathrm{Cl}$ & $5.38(-4.11,14.87)$ \\
\hline Scott 2006 & Six & 85 & 81 & $9.30(10.90)$ & $9.40(11.00)$ & WMD 95\% Cl & $-0.10(-3.43,3.23)$ \\
\hline Scott 2006 & Twelve & 85 & 81 & $8.30(10.50)$ & $8.00(8.10)$ & WMD $95 \% \mathrm{Cl}$ & $0.30(-2.55,3.15)$ \\
\hline \multicolumn{8}{|c|}{ Table 4. HDRS Score (Mean, SD) } \\
\hline Study & $\begin{array}{l}\text { Score at } \\
\text { ( months) }\end{array}$ & No in C group & No in T group & Control group score & $\begin{array}{l}\text { Treatment group } \\
\text { scor }\end{array}$ & $\begin{array}{l}\text { Satistical } \\
\text { method }\end{array}$ & Effect size \\
\hline Perry 1999 & Six & 32 & 25 & $3.40(4.00)$ & $4.00(3.90)$ & WMD 95\% Cl & $-0.60(-2.66,1.46)$ \\
\hline Perry 1999 & Twelve & 32 & 25 & $4.10(5.30)$ & $3.30(3.50)$ & WMD 95\% Cl & $0.80(-1.49,3.09)$ \\
\hline Perry 1999 & Eighteen & 32 & 25 & $3.90(4.40)$ & $5.00(6.00)$ & WMD 95\% Cl & $-1.10(-3.90,1.70)$ \\
\hline Lam 2000 & Six & 11 & 12 & $5.30(6.96)$ & $4.17(5.39)$ & WMD 95\% Cl & $1.13(-3.99,6.25)$ \\
\hline Lam 2000 & Twelve & 11 & 12 & $9.40(9.47)$ & $4.00(5.66)$ & WMD 95\% Cl & $5.40(-1.05,11.85)$ \\
\hline Scott 2006 & Six & 91 & 90 & $6.20(6.20)$ & $5.40(5.60)$ & WMD 95\% Cl & $0.80(-0.92,2.52)$ \\
\hline Scott 2006 & Twelve & 91 & 90 & $6.10(6.90)$ & $6.30(5.70)$ & WMD 95\% Cl & $-0.20(-2.04,1.64)$ \\
\hline Scott 2006 & Eighteen & 91 & 90 & $6.00(6.30)$ & $7.10(6.70)$ & WMD 95\% Cl & $-1.10(-3.00,0.80)$ \\
\hline Study & $\begin{array}{l}\text { Score at } \\
\text { (months) }\end{array}$ & No in C group & No in T group & $\begin{array}{l}\text { Control group } \\
\text { scores }\end{array}$ & $\begin{array}{l}\text { Treatment group } \\
\text { scor }\end{array}$ & $\begin{array}{l}\text { Satistical } \\
\text { method }\end{array}$ & Effect size \\
\hline Perry 1999 & Six & 25 & 32 & $0.30(0.70)$ & $0.40(1.10)$ & WMD 95\% Cl & $-0.10(-0.57,0.37)$ \\
\hline
\end{tabular}




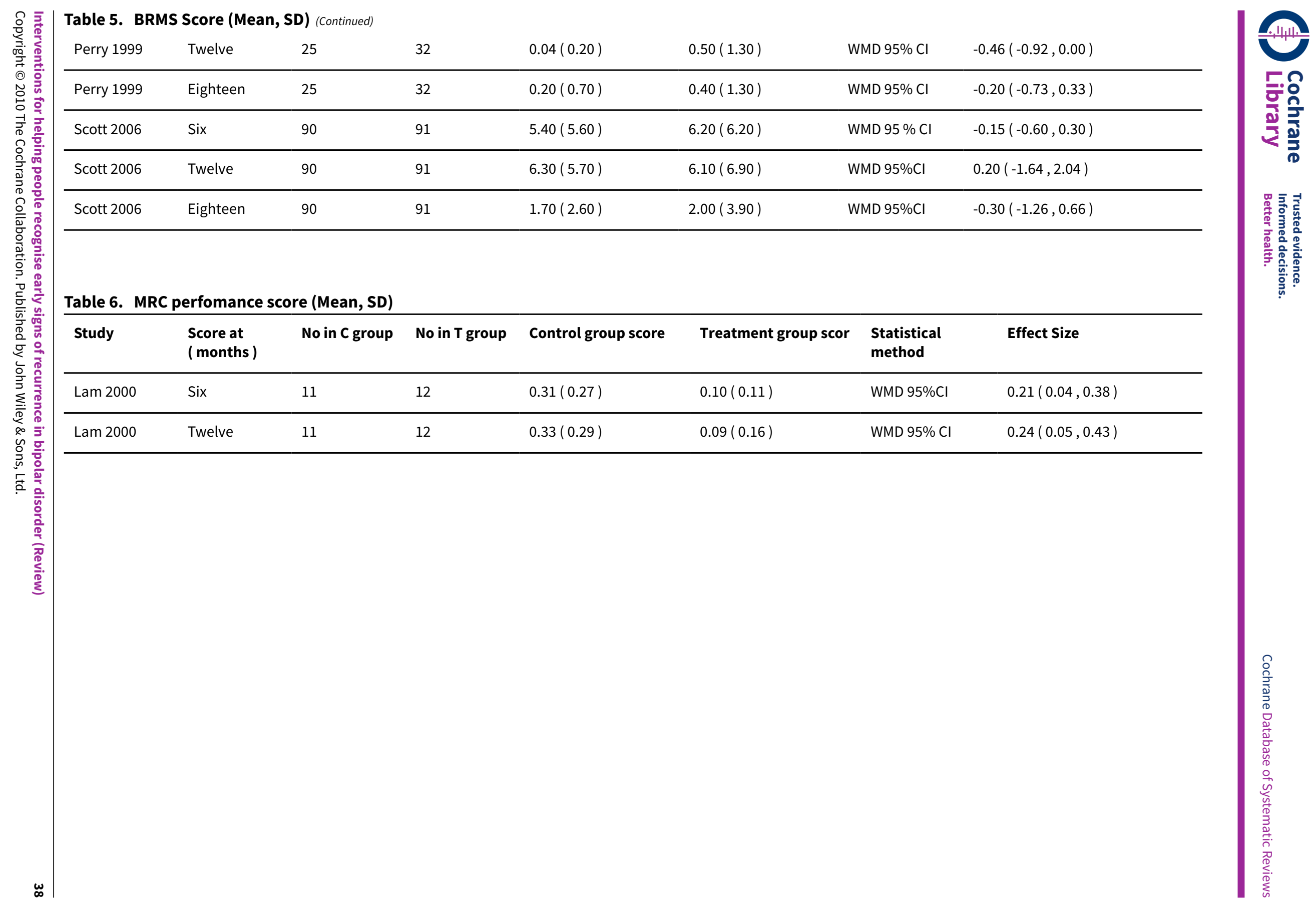


Table 7. Comparison 0201

\begin{tabular}{lllll}
\hline Outcome title & No of studies & $\begin{array}{l}\text { No of partici- } \\
\text { pants }\end{array}$ & Statistical method & Effect size \\
\hline $\begin{array}{l}\text { time to recurrence of any type for TAU + } \\
\text { EWS intervention in control group }\end{array}$ & 4 & 520 & $\begin{array}{l}\text { hazards ratio, random } \\
\text { effect, } 95 \% \mathrm{Cl}\end{array}$ & $0.65(0.41,1.03)$ \\
\hline $\begin{array}{l}\text { time to recurrence of any type for TAU + } \\
\text { psychological intervention in } \\
\text { control group }\end{array}$ & 2 & 170 & $\begin{array}{l}\text { hazards ratio, random } \\
\text { effect, } 95 \% \mathrm{Cl}\end{array}$ & $0.65(0.39,1.09)$ \\
\hline
\end{tabular}

Table 8. Meta-regression analyses

\begin{tabular}{lllll}
\hline Factor & $\begin{array}{l}\text { Number of } \\
\text { Studies }\end{array}$ & Slope Estimate & 95\% Cl & p-value \\
\hline Non-psychological / psychological intervention & 6 & 0.018 & $(-0.727$ to 0.762) & 0.963 \\
\hline $\begin{array}{l}\text { Inclusion six month after episode / during and im- } \\
\text { mediately after episode }\end{array}$ & 6 & 0.979 & $(0.615$ to 0.81$)$ & 0.788 \\
\hline
\end{tabular}

Table 9. Comparison 0202

\begin{tabular}{lllll}
\hline Outcome title & No of studies & $\begin{array}{l}\text { No of partici- } \\
\text { pants }\end{array}$ & Statistical method & Effect size \\
\hline $\begin{array}{l}\text { time to manic / hypomanic relapse for } \\
\text { TAU + EWS intervention }\end{array}$ & 3 & 413 & $\begin{array}{l}\text { hazards ratio, random ef- } \\
\text { fect }, 95 \% \mathrm{Cl}\end{array}$ & $0.70(0.39,1.25)$ \\
\hline $\begin{array}{l}\text { time to manic / hypomanic relapse for } \\
\text { TAU + psychological intervention }\end{array}$ & 1 & 120 & $\begin{array}{l}\text { hazards ratio, random ef- } \\
\text { fect , } 95 \% \mathrm{Cl}\end{array}$ & $0.52(0.33,0.82)$ \\
\hline
\end{tabular}

Table 10. Comparison 0203

\begin{tabular}{lllll}
\hline Outcome title & No of studies & $\begin{array}{l}\text { No of partici- } \\
\text { pants }\end{array}$ & Statistical method & Effect size \\
\hline $\begin{array}{l}\text { time to depressive episode for TAU + } \\
\text { EWS intervention }\end{array}$ & 3 & 413 & $\begin{array}{l}\text { hazards ratio, random ef- } \\
\text { fect, } 95 \% \mathrm{Cl}\end{array}$ & $0.66(0.36,1.22)$ \\
\hline $\begin{array}{l}\text { time to depressive episode for TAU + } \\
\text { psychological intervention }\end{array}$ & 1 & 120 & $\begin{array}{l}\text { hazards ratio, random ef- } \\
\text { fect, } 95 \% \mathrm{Cl}\end{array}$ & $0.38(0.24,0.62)$ \\
\hline
\end{tabular}

Table 11. Comparison 0205

\begin{tabular}{|c|c|c|c|c|}
\hline Outcome title & No of studies & $\begin{array}{l}\text { No of partici- } \\
\text { pants }\end{array}$ & Statistical method & Effect size \\
\hline
\end{tabular}


Table 11. Comparison 0205 (Continued)

\begin{tabular}{lllll}
$\begin{array}{l}\text { Time to first recurrence of any type for in- } \\
\text { tervention delivered individually }\end{array}$ & 3 & 419 & $\begin{array}{l}\text { hazards ratio, random } \\
\text { effect, } 95 \% \mathrm{Cl}\end{array}$ & 0.76 ( $0.49,1.18)$ \\
\hline $\begin{array}{l}\text { Time to first recurrence of any type for in- } \\
\text { tervention delivered in groups }\end{array}$ & 3 & 271 & $\begin{array}{l}\text { hazards ratio, random } \\
\text { effect, } 95 \% \mathrm{Cl}\end{array}$ & $0.56(0.37,0.87$ )
\end{tabular}

Table 12. Comparison 0206

\begin{tabular}{lllll}
\hline Outcome title & No of studies & $\begin{array}{l}\text { No of partici- } \\
\text { pants }\end{array}$ & Statistical method & Effect size \\
\hline $\begin{array}{l}\text { Time to first recurrence for any type in those } \\
\text { studies which recruit patients one month af- } \\
\text { ter episode }\end{array}$ & 4 & 336 & $\begin{array}{l}\text { hazards ratio, random } \\
\text { effect, } 95 \% \mathrm{Cl}\end{array}$ & $0.62(0.48,0.80)$ \\
\hline $\begin{array}{l}\text { Time to first recurrence for any type in those } \\
\text { studies which recruit patients during episode }\end{array}$ & 2 & 354 & hazards ratio, random & $0.66(0.24,1.77)$ \\
\hline
\end{tabular}

Table 13. Comparison 0207

\begin{tabular}{lllll}
\hline Outcome title & No. of studies & $\begin{array}{l}\text { No. of partici- } \\
\text { pants }\end{array}$ & Statistical method & Effect size \\
\hline $\begin{array}{l}\text { Time to first recurrence of any type in those } \\
\text { studies with simple intervention for EWS }\end{array}$ & 1 & 68 & $\begin{array}{l}\text { Hazards ratio, Random } \\
\text { effect } \\
95 \% \mathrm{Cl}\end{array}$ & $0.74(0.43,1.28)$ \\
\hline $\begin{array}{l}\text { Time to first recurrence of any type in those } \\
\text { studies with complex intervention for EWS }\end{array}$ & 5 & 622 & $\begin{array}{l}\text { Hazards ratio, Random } \\
\text { effect } \\
95 \% \mathrm{Cl}\end{array}$ & $0.54(0.35,0.83)$ \\
\hline
\end{tabular}

Table 14. Comparison 0208

\begin{tabular}{lllll}
\hline Otcome title & No. of studies & $\begin{array}{l}\text { No. of partici- } \\
\text { pants }\end{array}$ & Statistical method & Effect size \\
\hline $\begin{array}{l}\text { Time to manic / hypomanic episode for } \\
\text { studies with simple intervention for EWS }\end{array}$ & 1 & 68 & $\begin{array}{l}\text { Hazards ratio, random } \\
\text { effect } 95 \% \mathrm{Cl}\end{array}$ & $0.37(0.18-0.77)$ \\
\hline $\begin{array}{l}\text { Time to manic / hypomanic episode for } \\
\text { studies with complex intervention for EWS }\end{array}$ & 3 & 465 & $\begin{array}{l}\text { Hazards ratio, random } \\
\text { effect } 95 \% \mathrm{Cl}\end{array}$ & $0.76(0.46-1.26)$ \\
\hline
\end{tabular}

Table 15. Comparison 0209

\begin{tabular}{lllll}
\hline Outcome title & No of studies & $\begin{array}{l}\text { No of partici- } \\
\text { pants }\end{array}$ & Statistical method & Effect size \\
\hline $\begin{array}{l}\text { Time to depressive episode in those stud- } \\
\text { ies with simple intervention for EWS }\end{array}$ & 1 & 68 & $\begin{array}{l}\text { Hazards ratio, random } \\
\text { effect }\end{array}$ & $0.63(0.31-1.27)$ \\
\hline
\end{tabular}


Table 15. Comparison 0209 (Continued)

$95 \% \mathrm{Cl}$

\begin{tabular}{llll}
$\begin{array}{l}\text { Time to depressive episode in those stud- } \\
\text { ies with complex intervention for EWS }\end{array}$ & 3 & 465 & $\begin{array}{l}\text { Hazards ratio, random } \\
\text { effect } \\
95 \% \mathrm{Cl}\end{array}$ \\
\hline
\end{tabular}

Table 16. Comparison 0210

\begin{tabular}{lllll}
\hline Otcome title & No. of studies & $\begin{array}{l}\text { No. of partici- } \\
\text { pants }\end{array}$ & Statistical method & Effect size \\
\hline $\begin{array}{l}\text { Time to first recurrence of any type where } \\
\text { Ews was the primary focus of intervention }\end{array}$ & 5 & 437 & Hazards ratio, random & $0.58(0.45-0.73)$ \\
\hline $\begin{array}{l}\text { Time to first recurrence of any type where } \\
\text { EWS was secondary focus of intervention }\end{array}$ & 1 & 253 & $\begin{array}{l}\mathrm{Hazards} \text { ratio, random } \\
\text { effect, } 95 \% \mathrm{Cl}\end{array}$ & $1.05(0.74-1.49)$ \\
\hline
\end{tabular}

Table 17. Comparison 0211

\begin{tabular}{lllll}
\hline Outcome title & No of studies & $\begin{array}{l}\text { No of partici- } \\
\text { pants }\end{array}$ & Statistical method & Effect size \\
\hline $\begin{array}{l}\text { Time to manic / hypomanic episode for stud- } \\
\text { ies where EWS was used as primary focus of } \\
\text { the intervention }\end{array}$ & 3 & 280 & $\begin{array}{l}\text { Hazards ratio, ran- } \\
\text { dom effect, } 95 \% \mathrm{Cl}\end{array}$ & $0.53(0.38-0.74)$ \\
\hline $\begin{array}{l}\text { Time to manic / hypomanic episode for stud- } \\
\text { ies where EWS was used as secondary focus } \\
\text { of the intervention }\end{array}$ & 1 & 253 & $\begin{array}{l}\text { Hazards ratio, ran- } \\
\text { dom effect, } 95 \% \mathrm{Cl}\end{array}$ & $1.05(0.74-1.49)$ \\
\hline
\end{tabular}

Table 18. Comparison 0212

\begin{tabular}{lllll}
\hline Outcome title & No of studies & $\begin{array}{l}\text { No of partici- } \\
\text { pants }\end{array}$ & Statistical method & Effect size \\
\hline $\begin{array}{l}\text { Time to depressive episode in studies } \\
\text { which used EWS as primary focus of inter- } \\
\text { vention }\end{array}$ & 3 & 280 & $\begin{array}{l}\text { Hazards ratio, random } \\
\text { effect, } 95 \% \mathrm{Cl}\end{array}$ & $0.43(0.31-0.61)$ \\
\hline $\begin{array}{l}\text { Time to depressive episode in studies } \\
\text { which used EWS as primary focus of inter- } \\
\text { vention }\end{array}$ & 1 & 253 & Hazards ratio, random & $1.04(0.69-1.57)$ \\
\hline
\end{tabular}

Table 19. Comparison of baseline demographics of studies that reported primary outcomes

\begin{tabular}{|c|c|c|c|c|c|c|}
\hline Study ID & Colom 2003 & $\begin{array}{l}\text { Colom } 2003 \\
\text { (a) }\end{array}$ & Lam 2005 & Perry 1999 & Scott 2005 & Miklowitz 2003 \\
\hline
\end{tabular}


Table 19. Comparison of baseline demographics of studies that reported primary outcomes (Continued)

\begin{tabular}{|c|c|c|c|c|c|c|}
\hline AGE & $18-65$ & $\begin{array}{l}\text { 18-65, mean } \\
\text { (sd) } 34.5(7.8) \\
\text { in T and } 35.4 \\
(10.9) \text { in C }\end{array}$ & $\begin{array}{l}\text { 18-70, mean } \\
\text { (sd) 46.4(12.1) } \\
\text { in Treatment } \\
\text { and } 41.5(10.8) \\
\text { in Control }\end{array}$ & $\begin{array}{l}\text { 18-75, mean (sd) } \\
44(13) \text { in Treat- } \\
\text { ment and } 45(11) \\
\text { in Control }\end{array}$ & $\begin{array}{l}>18 \text { mean(sd) } \\
42.7(11.4) \text { in } C \text { and } \\
39.7(10.3) \text { in } T\end{array}$ & $\begin{array}{l}\text { 18-60, mean(sd) } \\
35.7(9.2) \text { in } T \\
\text { and35.6(10.6) in C }\end{array}$ \\
\hline GENDER & $\begin{array}{l}63.3 \% \text { fe- } \\
\text { malesin } \\
\text { control, } \\
63.3 \% \text { fe- } \\
\text { males in } \\
\text { treatment }\end{array}$ & $\begin{array}{l}\text { F:M }(15: 10) \text { in } \\
\text { control , }(16: 9) \\
\text { in treatment }\end{array}$ & $\begin{array}{l}\mathrm{F}: \mathrm{M}(28: 51) \\
\text { in control } \\
(30: 52) \text { in } \\
\text { treatment }\end{array}$ & $\begin{array}{l}\mathrm{F}: \mathrm{M}(24: 35) \text { in } \\
\text { control , (23:34) } \\
\text { in treatment }\end{array}$ & $\begin{array}{l}\mathrm{F}: \mathrm{M}(85: 127) \text { in T And } \\
79: 126 \text { in C }\end{array}$ & $\begin{array}{l}F: M(18: 31) \text { in TAnd } \\
(46: 72) \text { in } C\end{array}$ \\
\hline $\begin{array}{l}\text { REFERRAL } \\
\text { SOURCE }\end{array}$ & $\begin{array}{l}\text { Se- } \\
\text { condarycare }\end{array}$ & $\begin{array}{l}\text { secondary } \\
\text { care }\end{array}$ & $\begin{array}{l}\text { secondary } \\
\text { care }\end{array}$ & secondary care & Secondary care & Secondary care \\
\hline $\begin{array}{l}\text { MARITALS- } \\
\text { TATUS }\end{array}$ & Not stated & Not stated & Not stated & $\begin{array}{l}22 / 34 \text { in treat- } \\
\text { ment and } 21 / 35 \\
\text { in control were } \\
\text { married or co- } \\
\text { habiting }\end{array}$ & $\begin{array}{l}\text { Cohabiting56/126 in } \\
\mathrm{C} \text { and46/127 in T }\end{array}$ & $\begin{array}{l}\text { Not clear but re- } \\
\text { quiredContact with } \\
\text { carer }\end{array}$ \\
\hline $\begin{array}{l}\text { IN } \\
\text { EPISODEOR } \\
\text { NOT }\end{array}$ & $\begin{array}{l}\text { Euthymic } \\
\text { only }\end{array}$ & Euthymic only & $\begin{array}{l}\text { currently not } \\
\text { fulfilling bipo- } \\
\text { lar disorder } \\
\text { criteria }\end{array}$ & Euthymic & Yes, except mania & $\begin{array}{l}\text { Recruited shortly af- } \\
\text { ter Onset of acute } \\
\text { episode but } \\
\text { proportion unclear }\end{array}$ \\
\hline $\begin{array}{l}\text { HOW LONG } \\
\text { FROM PRE- } \\
\text { VIOUS } \\
\text { EPISODE }\end{array}$ & $\begin{array}{l}\text { In remission } \\
\text { For atleast6 } \\
\text { months }\end{array}$ & $\begin{array}{l}\text { At least six } \\
\text { months }\end{array}$ & Not stated & $\begin{array}{l}\text { mean }(\mathrm{sd}) \text { in } \\
\text { weeks } 25(16) \text { in } \\
\text { treatment and } \\
25(18) \text { in control }\end{array}$ & $\begin{array}{l}\text { Included those in- } \\
\text { Episode exceptMa- } \\
\text { nia. }\end{array}$ & Most in episode \\
\hline $\begin{array}{l}\text { NUMBER } \\
\text { OF PAST } \\
\text { EPISODE }\end{array}$ & $7-11$ & $7-11$ & $7-11$ & $1-6$ & $\begin{array}{l}\text { 2-6 episodes ( } 39 \text { in C } \\
\text { and } 35 \text { in T ) } \\
7-11 \text { episodes ( } 29 \text { in } \\
\text { C and } 25 \text { in T) } \\
12-29 \text { episode ( } 27 \text { in } \\
\text { C and } 32 \text { in T) } \\
30+\text { episode ( } 31 \text { in C } \\
\text { and } 35 \text { in T) }\end{array}$ & $1-6$ \\
\hline $\begin{array}{l}\text { SUBS- } \\
\text { TANCE } \\
\text { MISUSE }\end{array}$ & Not stated & Not stated & excluded & included & included & $\begin{array}{l}\text { Excluded substance- } \\
\text { Abuse and de- } \\
\text { pendenceln last } 6 \\
\text { months }\end{array}$ \\
\hline $\begin{array}{l}\text { RAPID CY- } \\
\text { CLING }\end{array}$ & $\begin{array}{l}\text { Included, } \\
\text { Unclear } \\
\text { what propor- } \\
\text { tion }\end{array}$ & Not stated & Not stated & Not stated & excluded & not stated \\
\hline $\begin{array}{l}\text { PERSON- } \\
\text { ALITY } \\
\text { DISORDER }\end{array}$ & included & included & excluded & included & included & not clear \\
\hline $\begin{array}{l}\text { PHYSICAL } \\
\text { ILLNESS }\end{array}$ & Not stated & Not stated & Not stated & Not stated & Not stated & $\begin{array}{l}\text { excluded neurologi- } \\
\text { cal problems, others } \\
\text { not clear }\end{array}$ \\
\hline
\end{tabular}


Table 19. Comparison of baseline demographics of studies that reported primary outcomes (Continued)

\begin{tabular}{|c|c|c|c|c|c|c|}
\hline $\begin{array}{l}\text { PSYCHOTIC } \\
\text { SYMPTOMS }\end{array}$ & $\begin{array}{l}\text { Present, } \\
42 / 60 \text { In } \mathrm{C} \\
\text { and } 47 / 60 \text { In } \\
T, P=N S\end{array}$ & $\begin{array}{l}\text { Present, } 19 / 25 \\
\text { In Control and } \\
23 / 25 \text { In Treat- } \\
\text { ment , P=NS }\end{array}$ & Not stated & Not stated & Not stated & not clear \\
\hline $\begin{array}{l}\text { SUICIDE } \\
\text { ATTEMPTS }\end{array}$ & yes & Not stated & Not stated & Not stated & Not stated & not clear \\
\hline $\begin{array}{l}\text { AXIS } 1 \text { CO- } \\
\text { MORBIDITY }\end{array}$ & excluded & excluded & excluded & included & included & not clear \\
\hline
\end{tabular}

Table 20. Comparison of focus of intervention of studies that reported primary outcome

\begin{tabular}{|c|c|c|c|c|c|c|}
\hline Study ID & $\begin{array}{l}\text { Colom } \\
2003\end{array}$ & $\begin{array}{l}\text { Colom } \\
\text { 2003(a) }\end{array}$ & Lam 2005 & Perry 1999 & Scott 2005 & $\begin{array}{l}\text { Miklowitz } \\
2003\end{array}$ \\
\hline EWS as primary Focus & yes & yes & yes & yes & no & yes \\
\hline EWS to patient Only & yes & yes & yes & yes & yes & no \\
\hline EWS to patient And Carer or Health worker & no & no & no & no & no & yes \\
\hline EWS delivered Individually & no & no & yes & yes & yes & no \\
\hline EWS delivered In groups & yes & yes & no & no & no & yes \\
\hline $\begin{array}{l}\text { EWS promoting Only help seekingFrom } \\
\text { others }\end{array}$ & no & no & no & yes & no & no \\
\hline $\begin{array}{l}\text { EWS promoting Additional self-Directed } \\
\text { coping }\end{array}$ & yes & yes & yes & no & yes & yes \\
\hline
\end{tabular}

Table 21. Comparison of intervention of studies that reported primary outcome

\begin{tabular}{|c|c|c|c|c|c|c|}
\hline Study Id & Colom 2003 & $\begin{array}{l}\text { Colom } \\
2003 \text { (a) }\end{array}$ & Lam 2005 & Perry 1999 & Scott 2005 & Miklowitz 2003 \\
\hline Duration & $\begin{array}{l}21 \text { weeks, weekly ses- } \\
\text { sions }\end{array}$ & $\begin{array}{l}20 \text { weeks, } \\
\text { weekly ses- } \\
\text { sions }\end{array}$ & $\begin{array}{l}12 \text { - } 18 \text { indi- } \\
\text { vidual ses- } \\
\text { sions in first } \\
\text { six months } \\
\text { and } 2 \text { boost- } \\
\text { er in second } 6 \\
\text { months }\end{array}$ & $\begin{array}{l}7-12 \text { sessions of } \\
\text { one hour each. } \\
18 \text { mths fol- } \\
\text { lowup. }\end{array}$ & $\begin{array}{l}\text { Weekly sessions- } \\
\text { For } 15 \text { weeks and } \\
\text { Then reducing } \\
\text { Frequency till- } \\
\text { Week } 26\end{array}$ & $\begin{array}{l}9 \text { months ( } 12 \\
\text { weekly then } 6 \\
\text { biweekly then } 3 \\
\text { monthly) }\end{array}$ \\
\hline Who did it & $\begin{array}{l}\text { Two experienced psy- } \\
\text { chologist }\end{array}$ & $\begin{array}{l}\text { Two experi- } \\
\text { enced psy- } \\
\text { chologist }\end{array}$ & $\begin{array}{l}\text { Clinical Psy- } \\
\text { chologists } \\
\text { With a mini- } \\
\text { mum Of } 5 \text { yrs }\end{array}$ & $\begin{array}{l}\text { Research Psy- } \\
\text { chologist with- } \\
\text { Little previous } \\
\text { experience }\end{array}$ & $\begin{array}{l}\text { Therapist with } \\
\text { Minimum criteria } \\
\text { to Be accredited } \\
\text { as CBT therapist in }\end{array}$ & $\begin{array}{l}\text { Therapist with } \\
\text { regular Super- } \\
\text { vision. }\end{array}$ \\
\hline
\end{tabular}


Table 21. Comparison of intervention of studies that reported primary outcome (Continued)

post Qualifi-

cation Experi-

ence

$\begin{array}{llll}\text { No. of ses- } & 21 \text { sessions of } 90 \text { min- } & 1800 \text { min- } & 13.9+5.5 \text { ses- } \\ \text { sionAttend- } & \text { utes each }=1890 \text { minut }\end{array} \quad \begin{aligned} & \text { utes } \\ & \text { sions }\end{aligned}$

ed

\begin{tabular}{|c|c|c|c|c|c|c|}
\hline $\begin{array}{l}\text { Control } \\
\text { group }\end{array}$ & $\begin{array}{l}\text { Standard pharmaco- } \\
\text { logic treatment and an } \\
\text { intervention consist- } \\
\text { ing of } 20 \text { weekly group } \\
\text { meetings of } 8-12 \text { pa- } \\
\text { tients with the same } \\
\text { psychologists who were } \\
\text { involved with treat- } \\
\text { ment group. The psy- } \\
\text { chologists tried not to } \\
\text { give any psychoedu- } \\
\text { cational feedback ex- } \\
\text { cept for that necessary } \\
\text { for patient interaction. } \\
\text { They were reviewed by } \\
\text { their psychiatrist at four } \\
\text { weekly intervals. }\end{array}$ & $\begin{array}{l}\text { Seen by } \\
\text { psychia- } \\
\text { trist every } \\
\text { four weeks } \\
\text { and stan- } \\
\text { dard phar- } \\
\text { macolog- } \\
\text { ical treat- } \\
\text { ment. Pa- } \\
\text { tients met } \\
\text { every week } \\
\text { in groups of } \\
8 \text { to } 12 \text { pa- } \\
\text { tients with- } \\
\text { out spe- } \\
\text { cial instruc- } \\
\text { tions from } \\
\text { therapist. }\end{array}$ & $\begin{array}{l}\text { - Control } \\
\text { group re- } \\
\text { ceived mood } \\
\text { stabilisers } \\
\text { at a recom- } \\
\text { mended lev- } \\
\text { el according } \\
\text { to BNF with } \\
\text { regular psy- } \\
\text { chiatric follow } \\
\text { up as outpa- } \\
\text { tients. }\end{array}$ & $\begin{array}{l}\text { delivered by psy- } \\
\text { chiatrists and } \\
\text { key workers con- } \\
\text { sisted of drug } \\
\text { treatment, mon- } \\
\text { itoring of mood } \\
\text { and adherence } \\
\text { to treatment, } \\
\text { support, educa- } \\
\text { tion about bipo- } \\
\text { lar disorder and } \\
\text { if necessary in- } \\
\text { patient care. }\end{array}$ & $\begin{array}{l}\text { - by usual psychi- } \\
\text { atric team. This in- } \\
\text { cluded prescrip- } \\
\text { tion of medication } \\
\text { and contact with } \\
\text { key mental health } \\
\text { professionals with } \\
\text { whatever frequen- } \\
\text { cy considered ap- } \\
\text { propriate. }\end{array}$ & $\begin{array}{l}\text { - two sessions } \\
\text { ( ONE HOUR } \\
\text { EACH ) of family } \\
\text { education plus } \\
\text { crisis interven- } \\
\text { tion sessions as } \\
\text { needed. } \\
\text { Study physi- } \\
\text { cians were al- } \\
\text { lowed to adjust } \\
\text { the frequency } \\
\text { of clinic visits } \\
\text { and drug and } \\
\text { dosage choices } \\
\text { to the needs of } \\
\text { the } \\
\text { individual pa- } \\
\text { tients. }\end{array}$ \\
\hline
\end{tabular}

WHAT'S NEW

\begin{tabular}{lll}
\hline Date & Event & Description \\
\hline 1 November 2008 & Amended & Converted to new review format. \\
\hline
\end{tabular}

\section{H I S T O R Y}

Protocol first published: Issue 3, 2004

Review first published: Issue 1, 2007

\begin{tabular}{lll}
\hline Date & Event & Description \\
\hline 30 October 2006 & $\begin{array}{l}\text { New citation required and conclusions } \\
\text { have changed }\end{array}$ & Substantive amendment \\
\hline
\end{tabular}

\section{CONTRIBUTIONS OF AUTHORS}

Catherine Bolton wrote first draft of protocol with Richard Morriss and liaised with CCDAN concerning search strategy. 
Richard Morriss originated the idea for the review and wrote first and revised draft of protocol and the review. Richard Morriss rated studies for inclusion and extracted data.

Jim McCarthy conducted first search, helped devise the protocol and commented on each draft.

Ashley Jones extracted primary outcome data, provided statistical expertise and commented on draft of the review.

Paula Williamson adjudicated data extraction, provided statistical expertise and commented on draft of the review.

Mohammad Faizal conducted handsearch, rated studies for inclusion, extracted secondary outcome data, conducted analysis and wrote the review with Richard Morriss.

\section{DECLARATIONS OF INTEREST}

One author (RM) is the co-author for two studies that were included in the review.

\section{SOURCES OF SUPPORT}

\section{Internal sources}

- University of Liverpool, UK.

- Mersey Care NHS Trust, UK.

\section{External sources}

- No sources of support supplied

\section{INDEX TERMS}

\section{Medical Subject Headings (MeSH)}

Bipolar Disorder [ ${ }^{\star}$ diagnosis] [prevention \& control]; Randomized Controlled Trials as Topic; Secondary Prevention

\section{MeSH check words}

Humans 